\title{
REGIONAL OPERATIONS RESEARCH PROGRAM \\ FOR DEVELOPMENT OF GEOTHERMAL ENERGY \\ IN THE SOUTHWEST UNITED STATES
}

\section{Project Director:}

J. M. Marlin

New Mexico Energy Institute New Mexico State Univers1ty

Third Querterly Report

by

Regional Project Staff

New Mexico Energy Institute

New Mexico State University

-

Apri1 1978

This project was conducted under the auspices of the NEW MEXICO ENERGY INSTITUTE at New Mexico State University. The research project was supported by the United States Department of Energy as Contract No. EG-77-5043992, by the Four Corners Regional Comission as Contract No. 672-066-075, and by the New Mexico Energy and Minerals Department as Project No. ERB 76-262. 


\section{DISCLAIMER}

This report was prepared as an account of work sponsored by an agency of the United States Government. Neither the United States Government nor any agency Thereof, nor any of their employees, makes any warranty, express or implied, or assumes any legal liability or responsibility for the accuracy, completeness, or usefulness of any information, apparatus, product, or process disclosed, or represents that its use would not infringe privately owned rights. Reference herein to any specific commercial product, process, or service by trade name, trademark, manufacturer, or otherwise does not necessarily constitute or imply its endorsement, recommendation, or favoring by the United States Government or any agency thereof. The views and opinions of authors expressed herein do not necessarily state or reflect those of the United States Government or any agency thereof. 


\section{DISCLAIMER}

Portions of this document may be illegible in electronic image products. Images are produced from the best available original document. 


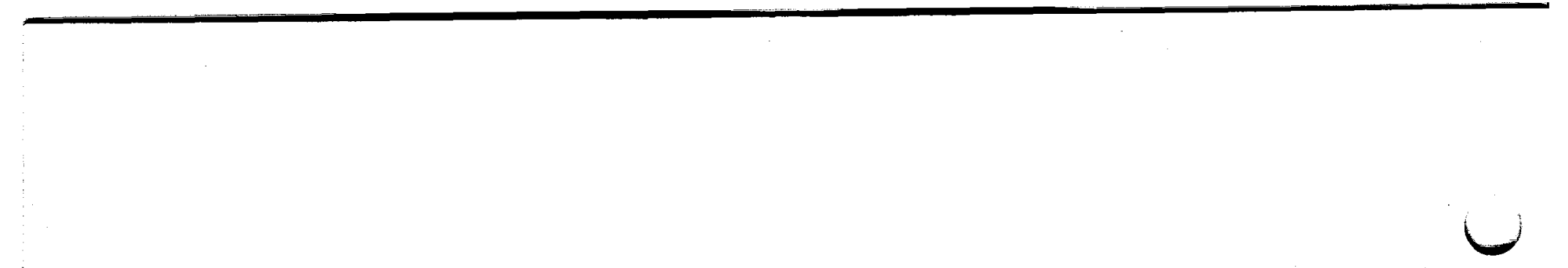

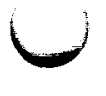

$\mathcal{U}$ 


\section{ACKNOWLEDGEMENTS}

The work reported here is the result of efforts of a core team at New Mexico State University and state teams from Arfzona, Colorado, Nevada, New Mexico, and Utah.

The N.M.S,U. Core Team is composed of:

Professors Richard Christ, Paul McDevitt, and Kenneth Nowotny of the Center for Business Services; Dr. C. R. Rao of Industrial Engineering; Professor Chandler Swanberg of Earth Sclences; Dave Mendive of Electrical Engineering; Patrick O'Dea of the Physical Sclence Laboratory.

The state teams are:

Arizona: James F. Warnock and Dr. Frank Mancini of the Arizona Solar Energy Research Commission; Professors Donald White and David Wolfe of University of Arlzona; Richard Hahman of Arizona Bureau of Geology and Mineral Technology.

Colorado: RIchard Pearl and Ms. Barbara Coe of Colorado Geological Survey:

Nevada: Noel Clark of the Nevada Department of Energy; Martin Booth, Ms. Barbara Helseth and Ms. Doris Weber.

New Mexico: Thomas Ortiz, Dennis Fedor and Wesley Horner of New Mexico Energy Resource Board.

Utah: Stan Green and Ward Wagstaff of Utah Division of Water Rights.

Graduate students are:

Ms. Mary Beth Ba11, W1lliam Ha11, Steve Martinez, John Nance, Ms. Sandra Rybarczyk, Awadhesh SIngh, and George Stephens.

Conclusions, opinions and other evaluative portions of this document solely reflect the views of the authors. Their inclusion herein does not indicate elther their acceptance or refection by the New Mexico Energy Institute at New Mexico State University, project subcontractors or any other cooperating or funding agencles. 
1. INTRODUCTION

1

2. WORK ACCOMPLISHED TO DATE 3
A. Economic Modeling
3-55

B. Progress in Identifying Institutional Factors

$57-70$

C. Third Quarterly Regional Advisory Group Meeting

71

D. RPPM Effort

73-76

E. State Team Reports

77-107

3. REFERENCES

109-110

\section{Appendices}

Appendix A

Assessment of Geothermal Site

111-127

Appendix B

A Simulation Model for the Economic Anaylsis of Geothermal Resources

Appendix C

Third Quarterly Reglonal Advisory Group Meeting Attendees

Appendices $D$, $E, F, G, \& H$

State Team Reports in Separate Cover 


\section{INTRODUCTION}

This report describes the work accomplished in the third quarter of the Regional Operations Research Program for Development of Geothermal Energy in the Southwest United States.

The work is being performed by a core team at New Mexico State University/ New Mexico Energy Institute, with subcontracts to state teams from Arizona, Colorado, Nevada, New Mexico, and Utah.

The objectives of the program are:

1) To develop realistic but aggressive scenarios with certainty factors for the development of each identified geothermal resource area in Arizona, Colorado, Nevada, New Mexico, and Utah.

2) To delineate the public actions, together with their schedules, required for the scenarios to materialize.

3) To develop a computer-based data storage and retrleval system of a reglonal program progress monitor to the level of a preliminary working model which is capable of displaying program approach, but not loaded with all avallable data. 


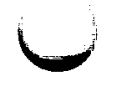


2. WORK ACCOMPLISHED TO DATE

\section{A. CORE TEAM ECONOMIC MODELING}

During the third quarter, sensitivity analysis of the economic models for both electric and non-electric applications for geothermal energy was considered. In addition, an attempt was made to aggregate the scenarios for the southwest region for the anticipated power on-1ine. The effort made in each Individual area is described below. The temperature data used in the economic analysis and scenario development are provided by Dr. Swanberg and the data are given in Appendix A. In addition, supplemental information provided by the state teams is utilized in the scenario development and other relevant analysis.

\section{GIRORA-Electric: Sensitivity Analysis}

As a result of discussion and suggestion at the Second Quarterly meeting, the Core Team has revised the Geothermal Internal Rate of Return Algorlthm (GIRORA) for electric usage. The model has been split into two sectors; namely, geothermal producer and electric utility. Moreover, each element of cost can be uniquely separated out for inspection. The price of electricity specifled 1s the busbar, rather than the retall price of electriclty. The detalls of the revised model are given in Appendix B. 
The purpose of the sensitivity analysis is, of course, to determine the sensitivity of the internal rate of return ( $R$ ) to changes in input parameters. This is a valuable tool for policy analysis. It reveals to what variables $R$ responds most readily and thus what might be the most efficient policy goals in terms of making geothermal energy an attractive investment.

First a "base case" must be chosen. It would be good if the "base case". is, in some way, "typical," but this is not crucial so long as the "base case" is not atypical. The important viewpoint in sensitivity analysis is the relative change in $R$ for a given change in the parameters. The absolute values of $R$ or the parameters, at least in this exercise, are not of overriding importance. "Base case" values for the exercises performed are shown in Table 1 .

The "base case" value of R maximizes at a 50 Mw utility plant and increases as resource temperature increases from about $7 \%$ per annum at $150^{\circ} \mathrm{C}$ to within excess of $100 \%$ per annum at $250^{\circ} \mathrm{C}$. (The $150^{\circ} \mathrm{C}-250^{\circ} \mathrm{C}$ range was chosen due to the fact that over 90 percent of resource sites in our 5-state area qualifying as electric sites lie in this range.) This is shown in Figure 1. Subsequent sensitivity analysis is, therefore, performed only upon plants of 50 Mw capacity.

At $230^{\circ} \mathrm{C}$, when the depletion allowance is at zero, $\mathrm{R}$ is approximately $26 \%$ per annum ("base case" data). Increasing depletion to a value of 22 percent increases $R$ to approximately $28 \%$ per annum at $230^{\circ} \mathrm{C}$ or $\frac{\Delta R}{R}=7.69 \%$. This is not an altogether promising result. This result is also illustrated in Figure 1.

A more interesting result is shown in Figure 2. This concerns the policy variable Investment Tax Credit Rate (CRRT). When CRRT is at the "base case". level, $R$ increases monotonically from left to right. But when CRRT is increased 


\begin{tabular}{|c|c|c|}
\hline & Variable & Value \\
\hline BR: & Bond Rate & 0.085 \\
\hline CRRT: & Investment Tax Credit Rate & 0.12 \\
\hline FR: & Flow Rate & $585,794 \mathrm{lb} / \mathrm{hr}$ \\
\hline TEMP: & Initial Downhole Temperature & $190^{\circ} \mathrm{C}$ \\
\hline EPK: & Equity Proportion of Capital & 0.70 \\
\hline DPK: & Debt Proportion of Capital & 0.30 \\
\hline$\lambda:$ & Royalty Rate & 0.10 \\
\hline Z: & Depletion Allowance Rate & 0.00 \\
\hline EXP : & Exploration Period & 0 years \\
\hline DVP : & Development Period & 8 years \\
\hline IXRT: & Income Tax Rate & 0.50 \\
\hline $\mathbf{R}:$ & Internal Rate of Return & 0.1392 \\
\hline
\end{tabular}

Geothermal Energy Producer

\begin{tabular}{|c|c|c|}
\hline & Varlable & Value \\
\hline CAP: & Capac1ty & $50,000 \mathrm{kw}$ (net) \\
\hline LF: & Plant Factor & 0.80 \\
\hline UF : & Plant Use of Power (Proportion) & 0.18 \\
\hline $\mathbf{P B}_{\mathrm{e}}$ : & Base Price of Electrlc1ty (Busbar) & $0.021(\$ / \mathrm{kwhr}$ \\
\hline P: & Escalation Rate of Base Price & 0.05 \\
\hline EK: & Equity Proportion of Capital & 0.50 \\
\hline DK: & Debt Proportion of Capital & 0.50 \\
\hline ER: & Regulated Return to Equity & 0.12 \\
\hline BR: & Bond Rate & 0.085 \\
\hline TXRT: & Income Tax Rate & 0.50 \\
\hline
\end{tabular}

\section{Electric Ut111ty}

Table 1. 


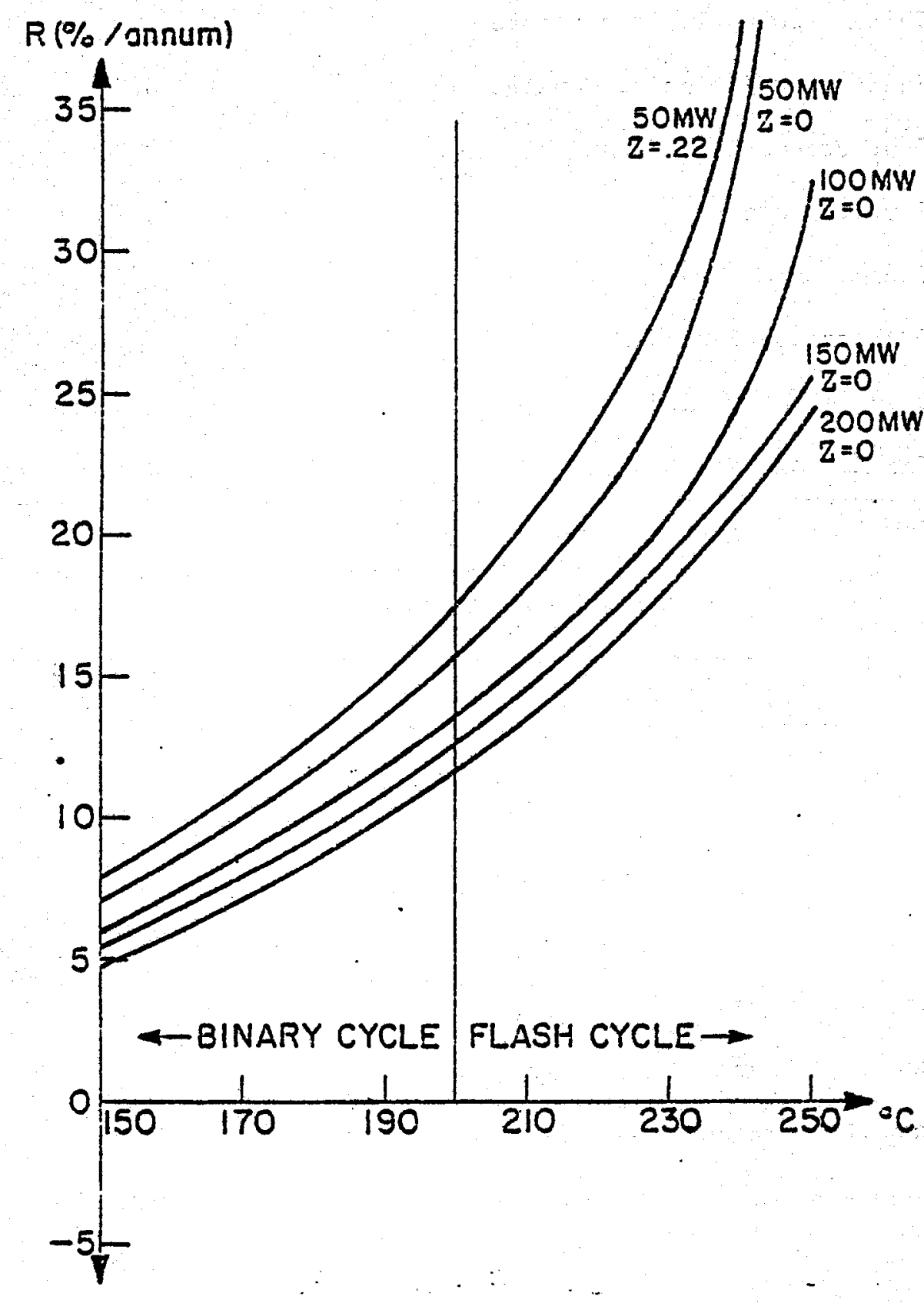

Figure 1: "Base Case" and Depletion Sensitivity 


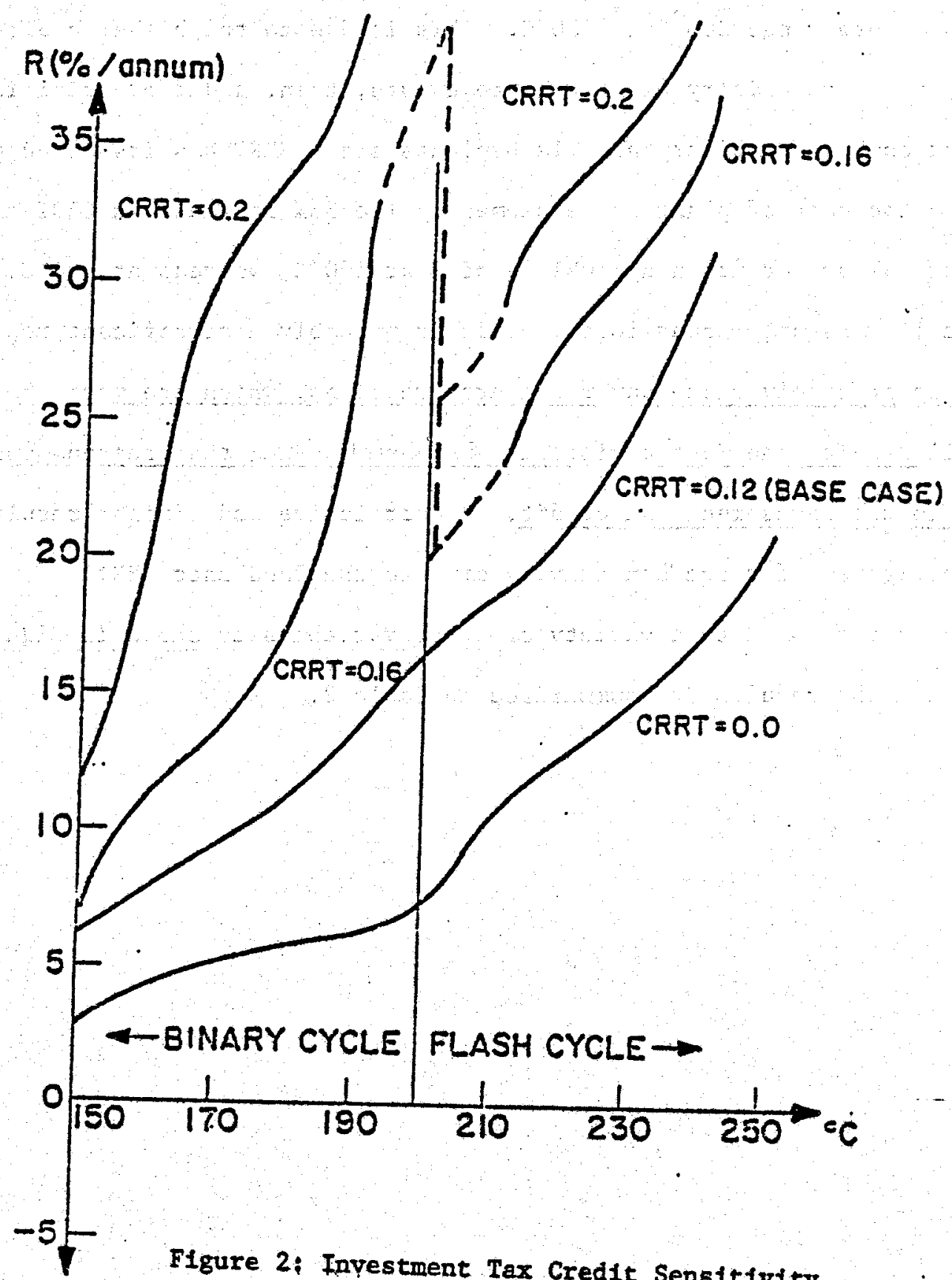

Figure 2; Inyestment Tax Credit Sensitivity 
from 1ts "base case" level, $12 \%$ to $16 \%$, this monotonic relationship changes. At temperatures between $185^{\circ} \mathrm{C}$ and $200^{\circ} \mathrm{C}$, there exist higher $\mathrm{R}$ values than in the temperature range $200^{\circ} \mathrm{C}$ to $230^{\circ} \mathrm{C}$. This is due to the higher capital sensitivity of the binary plant. There exists, then, a differential increase or effect as between binary and flash plants since CRRT has its principal impact on the cost of plant and equipment. The $33 \%$ increase in CRRT results In as much as or more than a doubling of $\mathrm{R}$ at $190^{\circ} \mathrm{C}$, whereas at $230^{\circ} \mathrm{C}$, the increase in $\mathrm{R}$ is only about $18.5 \%$. This is probably a significant result in that it is precisely those lower temperature sites, which are most abundant and that will reguire the most assistance for development; that respond most readily to the investment tax credit: A correlative and similar result is shown in Figure 3 for the sensitivity of $R$ to the Bond Rate (BR).

The sensivity of $R$ to a varlety of other variables is shown in Figures 4 thru 7, and the results are summarized in Table 2. 


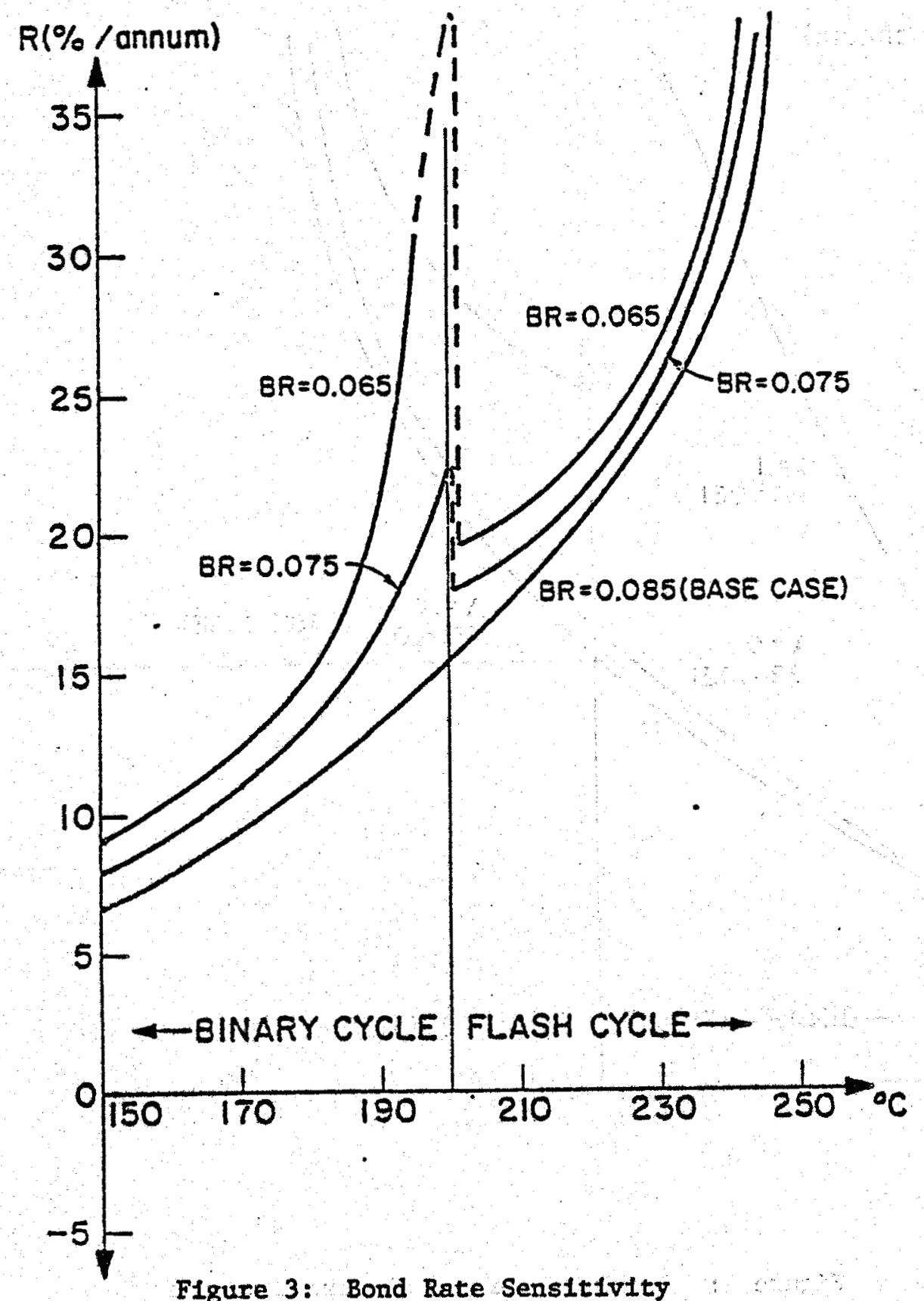

Figure 3: Bond Rate Sensitivity 


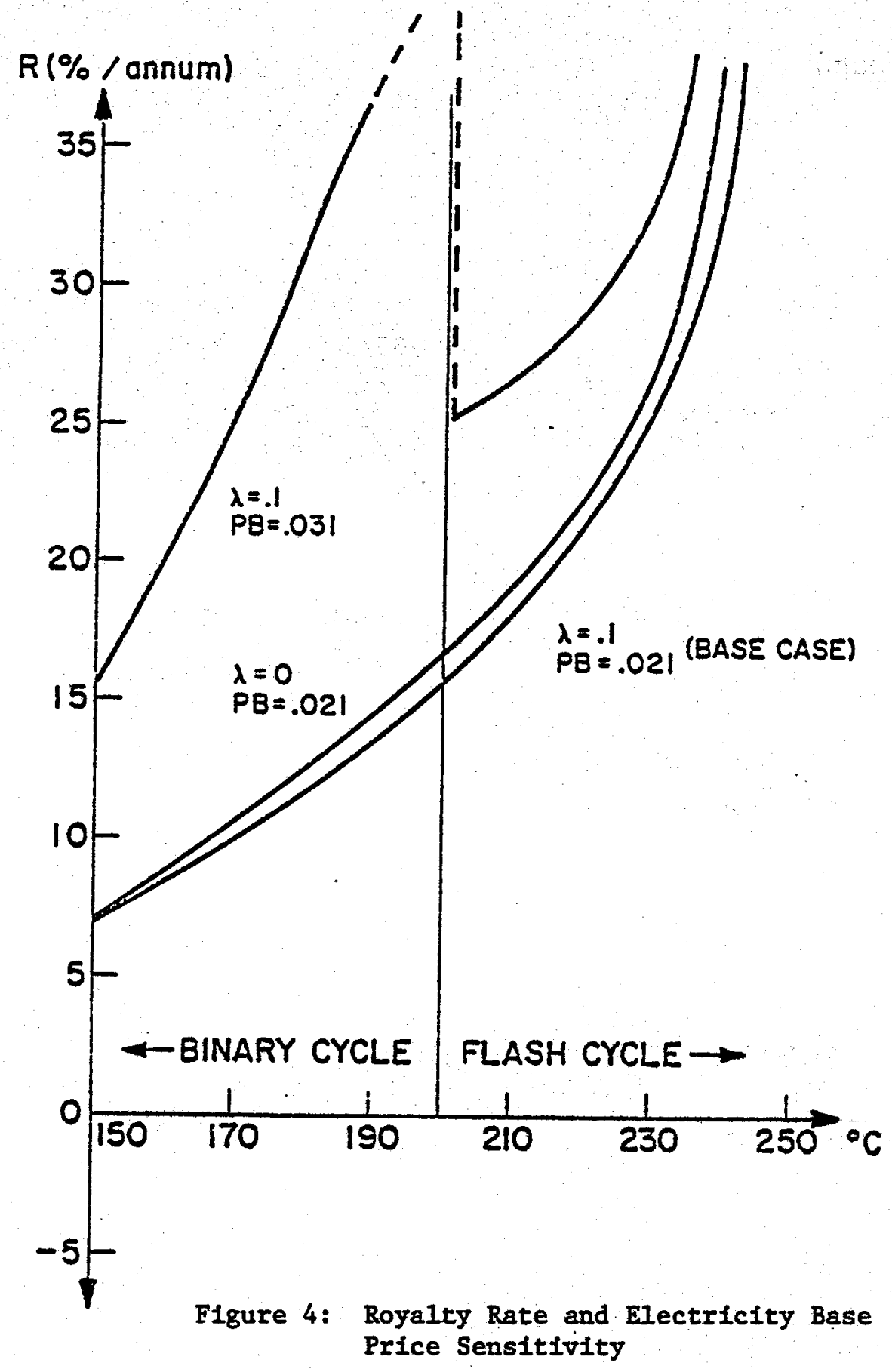




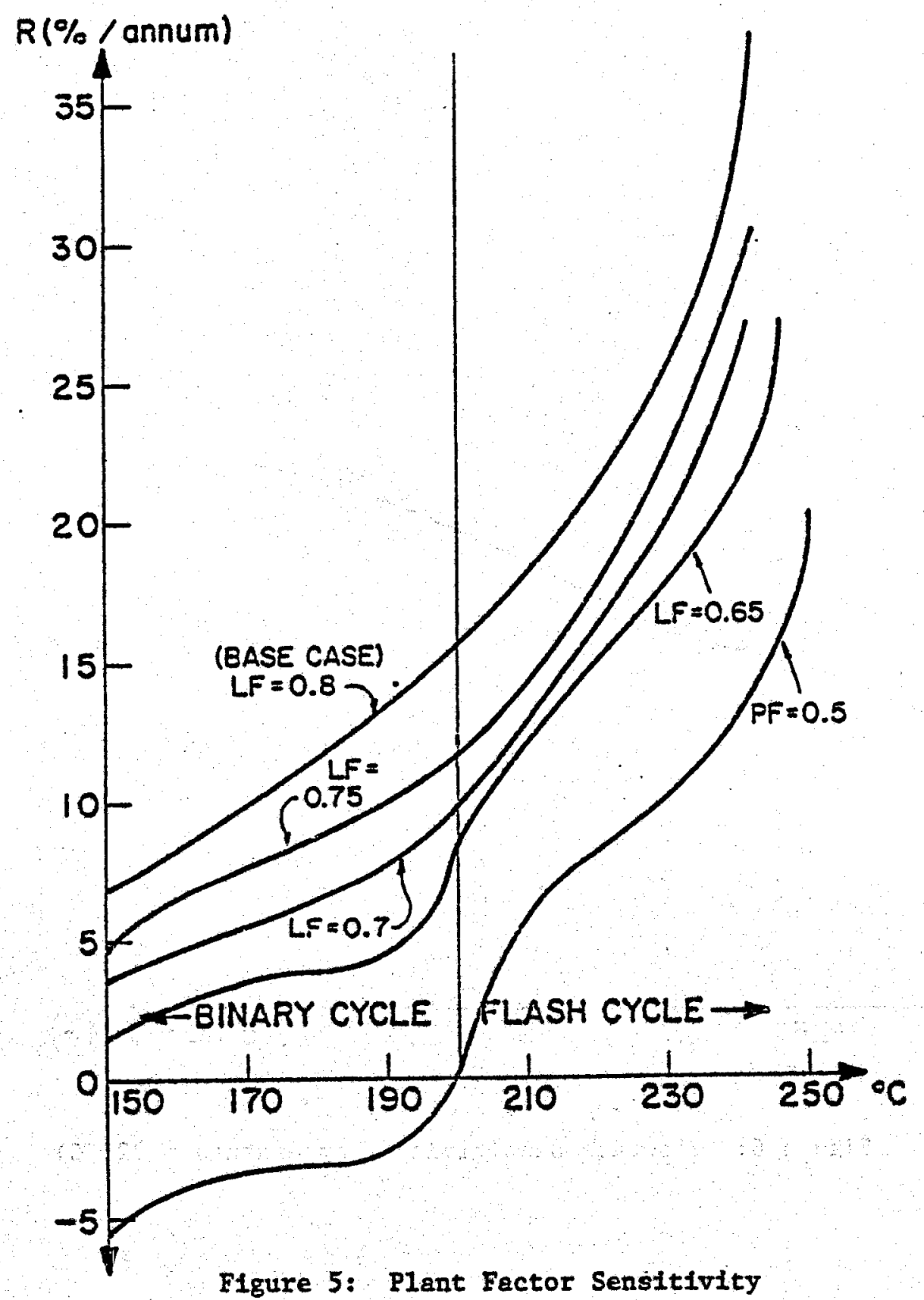




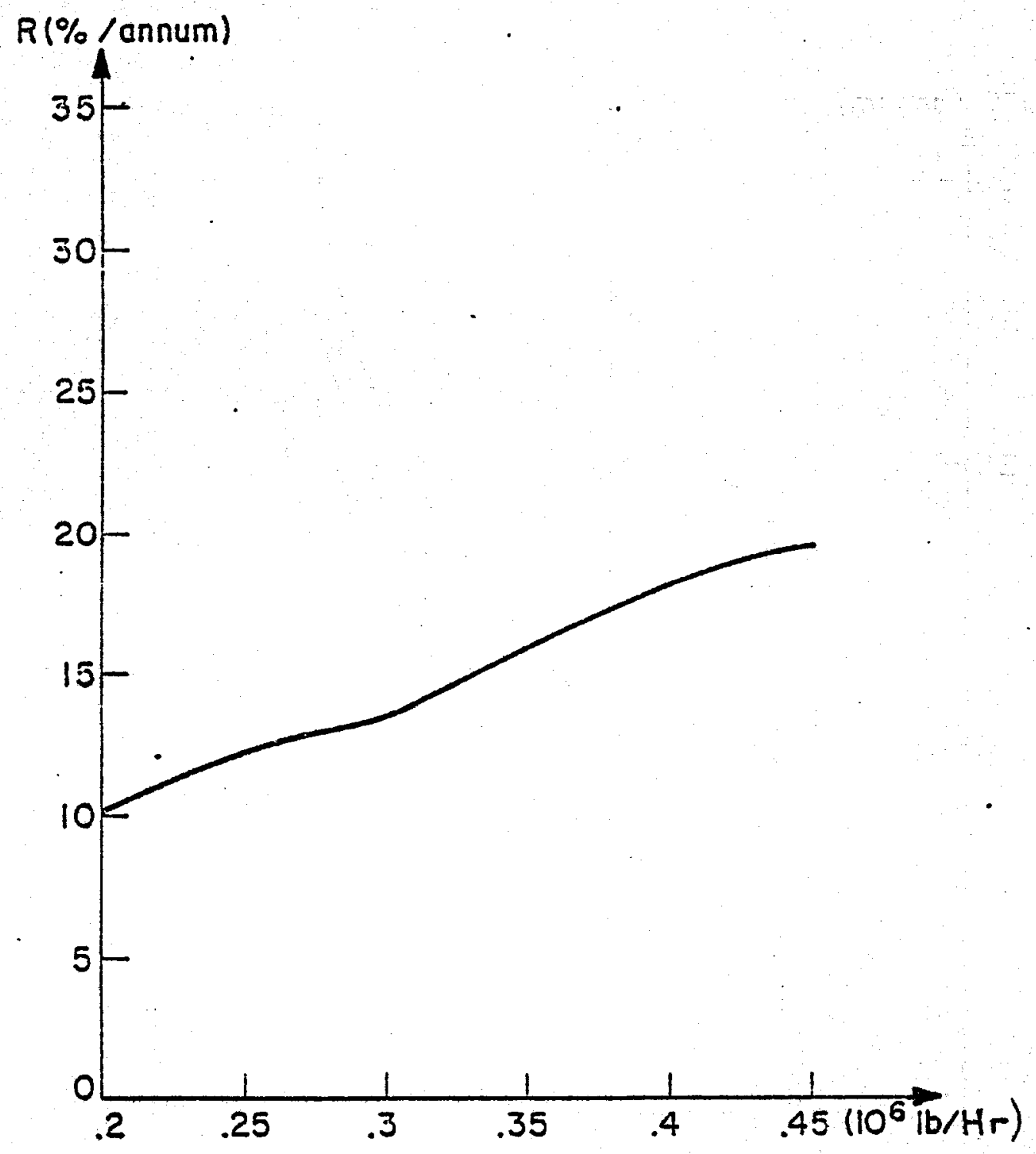

Figure 6: Flowrate Sensitivity (Temperature $=225^{\circ} \mathrm{C}$ ) 


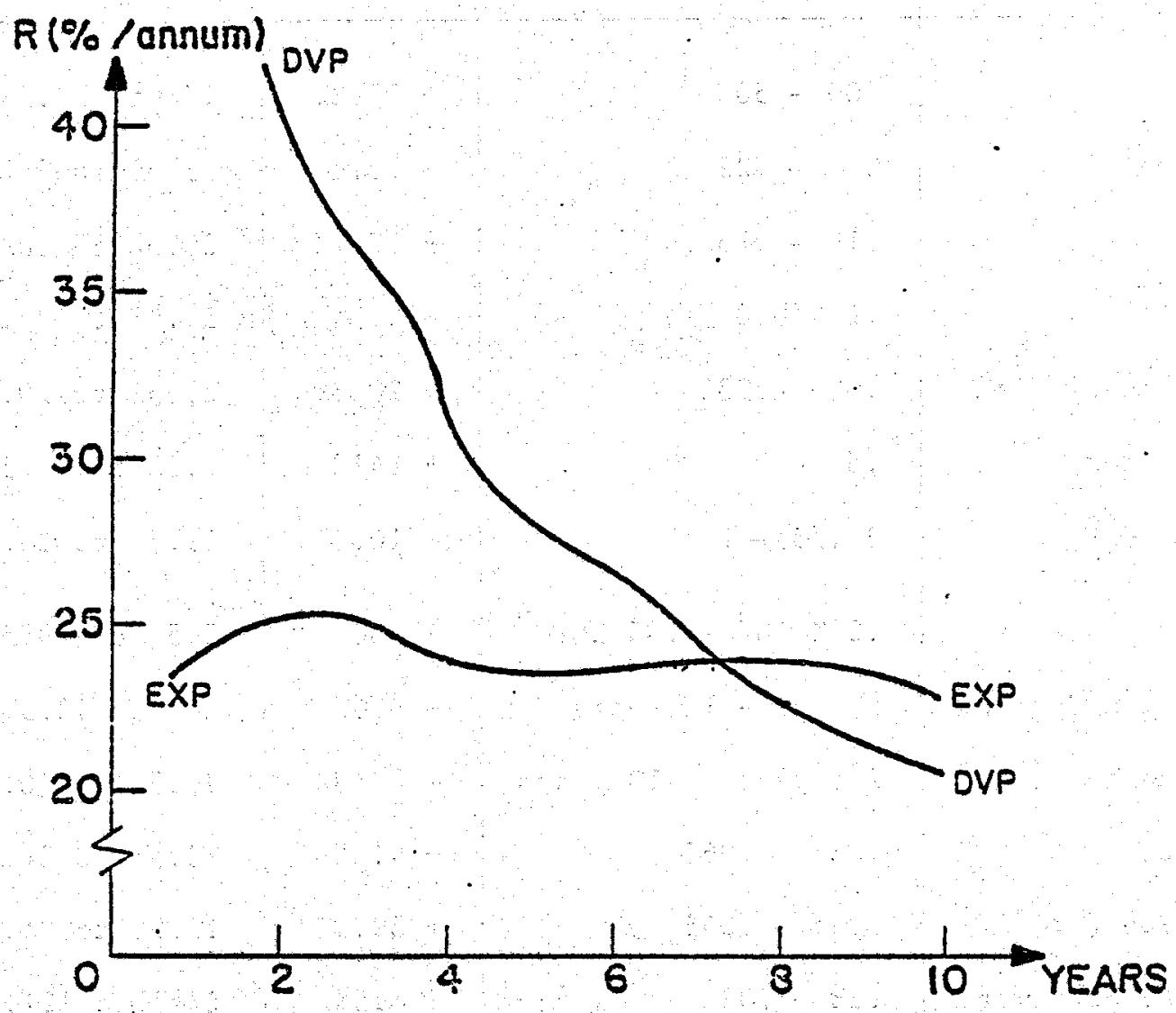

Figure 7: Sensttivity to Length of Exploration and Development Periods (Temperature $=225^{\circ} \mathrm{C}$ ) 


$$
\text { Temp }=225^{\circ} \mathrm{C}\left(437^{\circ} \mathrm{F}\right) \text { "Base Case" Values }
$$

\begin{tabular}{|c|c|c|c|}
\hline Variable & Range & $\frac{\Delta R}{R}$ & $\begin{array}{l}\text { Range of } \\
R \text { (\% per ann.) }\end{array}$ \\
\hline$M_{w}$ & $200-50$ & $+38.2 \%$ & $17 \%$ to $23.5 \%$ \\
\hline Depletion & $0 \quad-.22$ & $+10.6 \%$ & $23.5 \%$ to $26 \%$ \\
\hline CRRT & $.12-.16$ & $+27.7 \%$ & $23.5 \%$ to $30 \%$ \\
\hline Royalty & $.1-0.0$ & $+4.3 \%$ & $23.5 \%$ to $24.5 \%$ \\
\hline Base Price of Elec. & $.021-.031$ & $+29.8 \%$ & $23.5 \%$ to $30.5 \%$ \\
\hline Plant Factor & $.5-.8$ & $+147 \%$ & $9.5 \%$ to $23.5 \%$ \\
\hline Producer $\frac{\text { Debt }}{\text { Equity }}$ & $21 / 3-1$ & $-10.2 \%$ & $29.5 \%$ to $26.5 \%$ \\
\hline Flowrate & $.2 \times 10^{6}-.45 \times 10^{6}$ & $+160 \%$ & $7.5 \%$ to $19.5 \%$ \\
\hline Exploration Period & 1 year -10 years & $-6.3 \%$ & $24 \%$ to $22.5 \%$ \\
\hline Development Period & 2.5 years -10 years & $-43.8 \%$ & $36.5 \%$ to $20.5 \%$ \\
\hline Bond Rate & $.085-.065$ & $+4.3 \%$ & $23.5 \%$ to $24.5 \%$ \\
\hline *Bond Rate $\left(190^{\circ} \mathrm{C}\right)$ & $.085-.065$ & $+59.3 \%$ & $13.5 \%$ to $21.5 \%$ \\
\hline Plant Use of Power & $.18-.03$ & $+415 \%$ & 23.5 to $121.0 \%$ \\
\hline${ }^{*}$ Temp $(50 \mathrm{Mw})$ & $150^{\circ} \mathrm{C}-230^{\circ} \mathrm{C}$ & $+264 \%$ & $7 \%$ to $25.5 \%$ \\
\hline
\end{tabular}

Table 2: Summary of Sensitivity 


\section{Variance Analysis}

The variance analysis described below is an extension of the previously completed sensitivity analysis. In the sensitivity analysis, a "base case" was assumed and the change in $R$ was measured for a change in one variable, one at a time. What is now needed is to observe the variance in $R$ when several factors are varied simultaneously. The goal of this analysis as utilized here is to present an "optimistic" and a "pessimistic" outcome. We can with some certainty, then say in what range $R$ will likely be for any site, in this case, depending upon the temperature of the resource. Once again, the focus is on downhole temperature because $1 t$ is the parameter for which dataare most widely and readily avallable and for which, currently, the most rellable estimates exist. These are not, perhaps, the most compelling reasons for choosing a parameter as a focal point, but in the current state of accessible information, it is the best. we can do.

The values for parameters for the "optimistic case" and for the "pessimistic case" are summarized in Table 3. For a temperature of $225^{\circ} \mathrm{C}\left(437^{\circ} \mathrm{F}\right)$, the values of $\mathrm{R}$ in the two cases are shown. In the "optimistic case" $\mathrm{R}>100 \%$ per annum. In the "pessimistic case" $R$ is about $1.0 \%$ per annum. In short, the conjunction of a variety of fortunate or unfortunate factors can result in an extremely large variation in $R$, the internal rate of return to the producer. The range for $R$ across the spectrum of temperature is shown in Figure 8 .

A number of conclusions can be drawn from these results. First of all; no single factor is crucial in the evaluation of a geothermal resource as a business investment, so long as the volume of the resource is sufficient to support an electric plant. (Note: these results are for the production of electricity and do not pretend to evaluate the site for non-electric potential.) 


\begin{tabular}{|c|c|c|}
\hline Variable & "Pessimistic" Value & "Optimistic" Value \\
\hline Mw & 50 & 50 \\
\hline FR/Well & $250,000 \mathrm{lb} / \mathrm{hr}$ & $400,000 \mathrm{lb} / \mathrm{hr}$ \\
\hline$\lambda$ & .1 & .05 \\
\hline$z$ & 0.0 & 0.22 \\
\hline$L F$ & .6 & .75 \\
\hline PB & .021 & .030 \\
\hline$\dot{\mathrm{P}}$ & .05 & .055 \\
\hline$D / E$ (Prod.) & 1.5 & 1.86 \\
\hline ER & .15 & .12 \\
\hline $\mathrm{BR}$ & .085 & .075 \\
\hline EXP & 5 & 5 \\
\hline DVP & 8 & 5 \\
\hline
\end{tabular}

Table 3: "Pessimistic" and "Optimistic" Parameter Values 


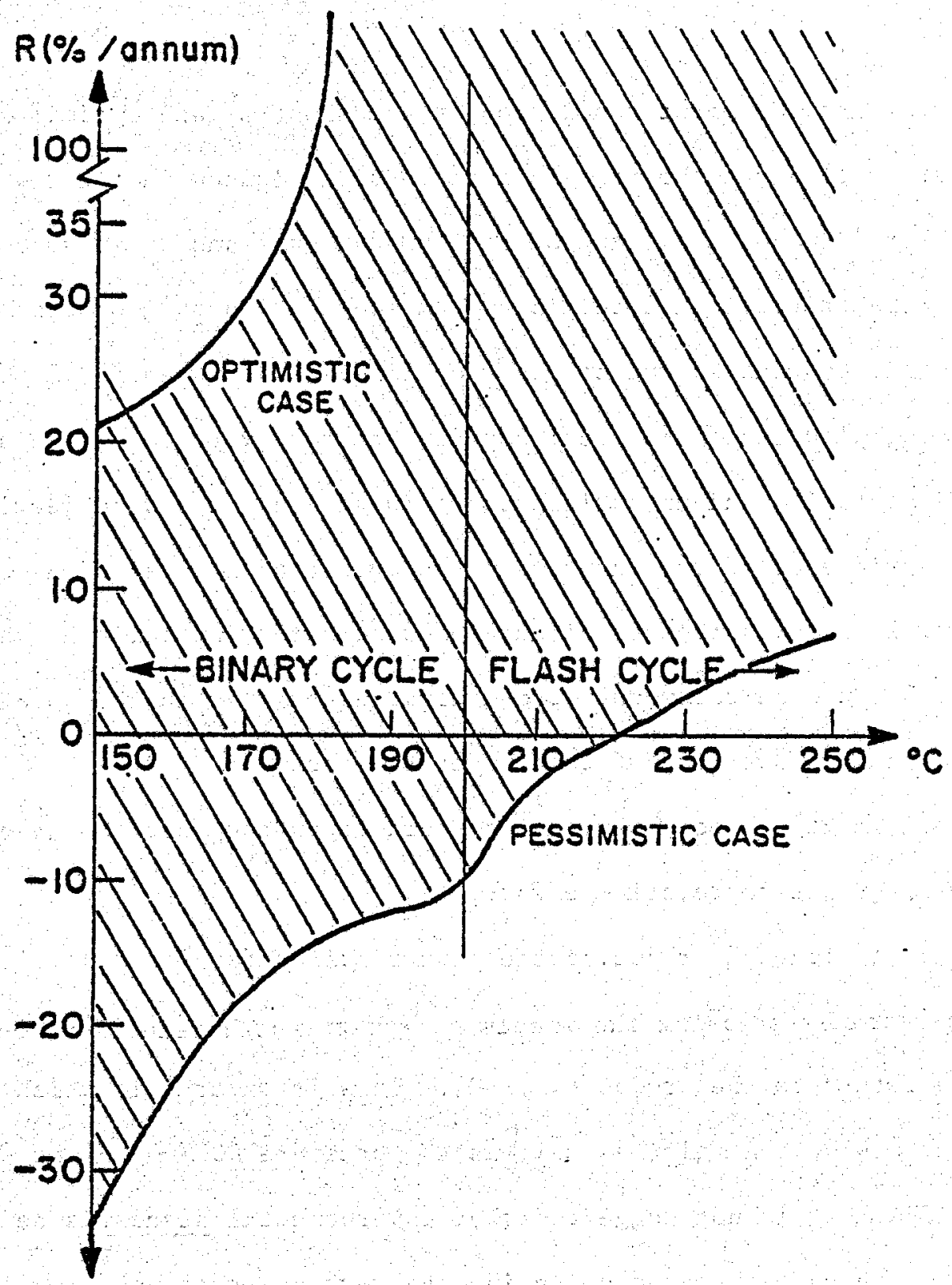

Figure 8. Potential Range of Profitablilty for Geothermal Energy Sites 
Secondly, in general, the higher the temperature, the greater will be the return on investment, given that salinity problems will not be of overriding importance.

Thirdly, given the first conclusion, the enthusiasm and optimism of the developer is likely to be of considerable significance in the development of a particular site and thus, the overall enthuslasm and optimism of the industry will be critical in determining the speed at which geothermal energy develops as an important source of power on-line. To this end, DOE-DGE especially, but also state and local governments must work to create a climate in which this optimism and enthusiasm can grow and in the end be justified. Insuring the existence of the investment tax credit at a level of around $16 \%$, and providing loan guarantees or direct loans at something below prevailing interest rates could be enormously productive, especially in the development of resources at the lower end of the temperature scale.

The development of techrology which would lower the cost of binary plants would be an important correlative effort.

As noted in Figure 7 , reducing the time required for field development from 6 to 3 years, by greasing the wheels of government bureaucracy, could increase the return to the producer by $50 \%$. This is an area in which state and local governments have a role, as well as the pressure DOE/DGE might bring to bear on the EPA. It is not suggested that environmental standards be relaxed, but rather, there must be a reduction in paperwork and response time in allowing producers to meet those standards.

Again, it is the conjunction of all of these elcments and others which will insure the full and timely development of geothermal energy. The magnitude of the impact of such a conjunction has been estimated and is the subject of our presentation on scenario aggregation. 


\section{SCENARIO AGGREGATION AND SENSITIVITY: ELECTRIC}

Scenario aggregation is, simply enough, the adding up of the net energy output of known likely sites in a picture of the process of geothermal development through time. Ideally, this is an exercise in "adding up," that is, putting pieces together, pieces which have been designed by those closest to the resource development. Our job at the core team is to see what kind of picture all the pieces make.

Designing the pieces has, however, turned out to be a more time-consuming and arduous task than invisioned. Moreover, what we do know is that the' pieces we receive are, at best, of a provisional, conditional nature. This will be true for every resource site until that particular project is shut down. As time passes, the pieces receive honing and refinement, but they can never really be complete, exact, or precise. At this date, the pieces are still very rough. The aggregation then, for our five-state region, is an accumulation of very rough pieces and guesses about what very rough pieces might look like.

To the extent that we have received rough guesses about site scenarios, they have been incorporated in our aggregation. Thus our aggregation may be somewhat more refined than one from an even further remove.

The process of aggregation by the core ream was begun in full cognizance of the limitations and provisional nature of the available data. It was in this light that we adopted the pracedures discussed below. 


\section{Site Analysis}

Each known and likely resouce for electric power was considered individually. The best available information was used for each site. In the absence of alternative information, USGS "Circular 726" was our source for quantity data. If information from a resource developer was available, this was the source utilized.

In quantifying a resource from 726 data, the estimated (or default) reservoir volume in $\mathrm{km}^{3}$ and estimated temperature (downhole) were converted to calories of stored heat. This was then translated into megawatt equivalent centuries for electric potential. Each megawatt entury contains $31 / 3$ thirty-year megawatts of capacity. Thus the stored heat in calories was converted into megawatt equivalents of thirty-year life spans. The megawatt result compares favorably with those which assume conversion efficiencies and estimate enthalpy.

No effort was made to rigorously estimate a range within which the calculation might be a mean. The uncertainties surrounding the estimate of reservoir volume and geochemical estimates of downhole temperature are sufficient without adding the surrealism of pseudo-statistics.

Thus each site was evaluated initially on the bas is of the number of thirty-year life megawatt equivalents contained in the reservoir.

Then using the estimate of temperature, each site was evaluated on the basis the Internal Rate of Return to the producers equity (R) calculated by GIRORA-Electric. An $R$ was calculated according to the "base case" values of parameters, the "optimistic" and "pessimistic" values of parameters. Since no probability was assigned to the various parameter values, no probability can be assigned to the $R$ result. 
The sites, thus evaluated, are listed in Tables 4 thru 9. Where . "optimistic" and "pessimistic" evaluations existed from developers or others close to the development of a resource, these figures were used. Those sites marked with an asterisk (*) were evaluated other than from "Circular 726 ".

Therefore on the basis of either physical or economic properties, there exists a "pessimistic" and an "optimistic" scenario for, from the point of view of aggregation, each site. These two estimates, in effect, define the "likely" range of sensitivity of geothermal development to conditional events. (Likely is within quotation marks because it is, deliberately, an imprecise word. As no probability has been assigned to events or parameter values, no confidence region can be assigned to the resulting limits. By "likely" we mean that our best guess, given our current information, is that this will be the range in which development will occur at better than 50-50 odds.) More, better, different, etc., information might alter or simply sharpen our estimates.

After the determination of a "pessimistic" and an "optimistic" case, each site was brought "on line" on a "no-competition--for resources" basis. For a multi-plant resource site, electric plants were phased in through time on a fairly arbitrary basis. $50 \mathrm{kw}$ increments were used because GIRORAElectric tells us that this is the optimal plant size. This of course assumes that each plant will be judged upon its net addition to project profits. There are then two aggregate scenarios: an "optimistic" one, and a "pessimistic" one.

The time phased scenarios are shown in figures 9 thru11,and a graph of the two aggregate scenarios is shown in Figure 12. The result of alternative assumptions about reservoir volumes, life spans and technology are illustrated in Figure 13. 


\begin{tabular}{|ccccccc|}
\hline Site & Temp. $\left({ }^{\circ} \mathrm{C}\right)$ & $\vec{R}$ & $R_{0}$ & $R_{p}$ & $M_{0}$ & $M w_{p}$ \\
\hline Power Ranch & 184 & $(.10-.15)$ & $>100$ & $<0$ & 50 & 0 \\
Clifton & 160 & $(.05-.10)$ & $(.2-.3)$ & $<0$ & 50 & 0 \\
Verde H.S. & 150 & $(.05-.10)$ & $(.2-.3)$ & $<0$ & 50 & 0 \\
\hline & & & & TOTAL & 150 & 0 \\
\hline
\end{tabular}

Table 4. Arizona

\begin{tabular}{|c|c|c|c|c|c|c|}
\hline Site & Temp. $\left({ }^{\circ} \mathrm{C}\right)$ & $\bar{R}$ & $R_{0}$ & $R_{p}$ & Mwo & $M_{p}$ \\
\hline Mt. Princeton* & & & & & 100 & 100 \\
\hline Poncha Sprg.* & (?) & & & & 200 & 100 \\
\hline Cebolla Sprg.* & (Binary) & & & & 200 & 0 \\
\hline & & & & TOTAL & 500 & 200 \\
\hline
\end{tabular}

Table 5. Colorado

$\bar{R}=$ "Base Case", with $Z=.22, \lambda=.1$

$R_{0}=$ Optimistic $R$

$R_{p}=$ Pessimistic $R$

$$
\begin{aligned}
& M w_{0}=\text { Capacity given } R_{0} \\
& M w_{p}^{\prime}=\text { Capacity given } R_{p}
\end{aligned}
$$




\begin{tabular}{|c|c|c|c|c|c|c|}
\hline Site & Temp. $\left({ }^{\circ} \mathrm{c}\right)$ & $\bar{R}$ & $R_{0}$ & $R_{p}$ & Mw 0 & $M p$ \\
\hline Beowawe & 240 & $>100$ & $>100$ & $(.10-.20)$ & 650 & 600 \\
\hline Brady & 214 & $(.2-.25)$ & $>100$ & $(0-.1)$ & 400 & 300 \\
\hline Steamboat & 210 & $(.2-.25)$ & $>100$ & $(0-.1)$ & 250 & 150 \\
\hline Sulphur H.S. & 190 & $(.1-.15)$ & $>100$ & $<0$ & 100 & 0 \\
\hline Hot Sulphur $S$. & 185 & $"$ & $"$ & $"$ & 50 & $"$ \\
\hline Jersey Valley & 185 & $"$ & $"$ & $"$ & 50 & " \\
\hline Near Wells & 180 & $"$ & $"$ & $"$ & 50 & $"$ \\
\hline Kyle H.S. & 180 & $"$ & $"$ & $"$ & 50 & $"$ \\
\hline H.S. Ranch & 180 & $"$ & $n$ & 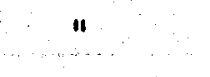 & 50 & $"$ \\
\hline Lee H.S. & 175 & $"$ & $"$ & $"$ & 50 & $"$ \\
\hline Gerlach & 170 & " & $"$ & ". & 50 & $"$ \\
\hline Leach & 170 & $"$ & $"$ & $"$ & 50 & $"$ \\
\hline Baltazor & 170 & $(.1-.15)$ & $>100$ & $"$ & 50 & $"$ \\
\hline Pinto & 165 & $(.05-.1)$ & $(.2-.3)$ & $"$ & 50 & $"$ \\
\hline Soda Lake & 165 & $"$ & $"$ & $"$ & 100 & $"$ \\
\hline Still Water & 160 & $"$ & $"$ & $"$ & 200 & $"$ \\
\hline Snith G. $V$. & 160 & $"$ & $"$ & $"$ & 50 & $\because$ \\
\hline Wabuska & 155 & $"$ & $\because$ & $"$ & 50 & 1 \\
\hline Black Rock & 150 & i & $"$ & $"$ & 50 & $"$ \\
\hline Dixie & 150 & $(.05-.1)$ & $(.2-.3)$ & $"$ & 50 & 4 \\
\hline \multirow[t]{2}{*}{ Great Boiling } & 170 & $(.1-.15)$ & $>100$ & " & 250 & 11 \\
\hline & & 4 & $\therefore \quad$ का & TOTAL & 2750 & 1050 \\
\hline
\end{tabular}

Teble 6. Nevada 


\begin{tabular}{|cccccccc|}
\hline Site & Temp $\left({ }^{\circ} \mathrm{C}\right)$ & $\bar{R}$ & $R_{0}$ & $R_{p}$ & $A_{W}$ & $M_{w}$ \\
\hline Valles Caldera & 240 & $>100$ & $>100$ & $(.1-.2)$ & 2000 & 1900 \\
Lightning Dock & 170 & $(.1-.15)$ & $>100$ & $<0$ & 50 & 0 \\
Kilbourne Hole & 155 & $(.05-.1)$ & $(.2-.3)$ & $<0$ & 50 & 0 \\
Lower San Fr. H.S. & 150 & $(.05-.1)$ & $(.2-.3)$ & $<0$ & 50 & 0 \\
Radium Sp. & 160 & $(.05-.1)$ & $(.2-.3)$ & $<0$ & 50 & 0 \\
\hline & & & & Total & 2200 & 1900 \\
\hline
\end{tabular}

Table 7. New Mexico

\begin{tabular}{|lcccccc|}
\hline Site & Temp $\left({ }^{\circ} \mathrm{C}\right)$ & $\bar{R}$ & $R_{0}$ & $R_{p}$ & $M_{0}$ & $M_{p}$ \\
\hline Roosevelt H.S.* & 230 & $(.25-.3)$ & $>100$ & $(0-.1)$ & 500 & 300 \\
Cove Fort & 200 & $(.15-.2)$ & $>100$ & $<0$ & 250 & 0 \\
Thermo & 200 & $(.15-.2)$ & $>100$ & $<0$ & 50 & 0 \\
\hline & & & & Total & 800 & 300 \\
\hline
\end{tabular}

Table 8. Utah 


\begin{tabular}{|lcc|}
\hline STATE & Mwo & Mwp \\
\hline Arizona & 150 & 0 \\
Colorado & 500 & 200 \\
Nevada & 2750 & 1050 \\
New Mexico & 2200 & 1900 \\
Utah & 800 & 300 \\
\hline Total & & 3500 \\
\hline
\end{tabular}

Table 9. Five-State Region 


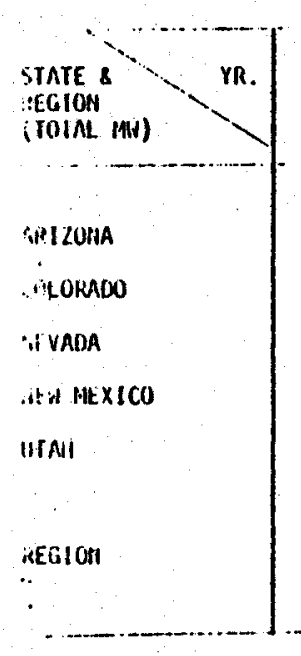

19xx Power on Line [stinate (Optimistic)

$20 \times x$

$\begin{array}{llllllllllllllllllllllllllllllllllllllllllllllllllllllll}80 & 81 & 02 & 83 & 84 & 85 & 86 & 87 & 88 & 89 & 90 & 91 & 92 & 93 & 94 & 95 & 96 & 97 & 98 & 99 & 00 & 01 & 02 & 03 & 04 & 05 & 06 & 07 & 08 & 09 & 10 & 11 & 12 & 13 & 14 & 15 & 16 & 17 & 18 & 19 & 20 & 21\end{array}$

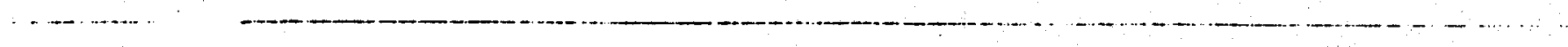

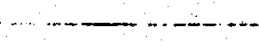

050100150 -

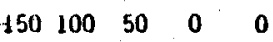

$0 \quad 150150200260300400500 \quad 500500350350300200 \quad 200$

.050100150200350700900110016001850205022002300240025002600265027002750

27502700265026002550240020501850160015501550

050505010015020030040050060065070075080085090035010001050110011501200125013001350140014501500155016001600165017001700170017001610160015501500

$050100100100150300350400500600700800+800750700700700650500450400300200$

$015025030040065013501750220029503500395043504500465048004950505051505250530053505400545054505550560056505700575056505600540047504400395) 32002800$

\section{Figure 9}




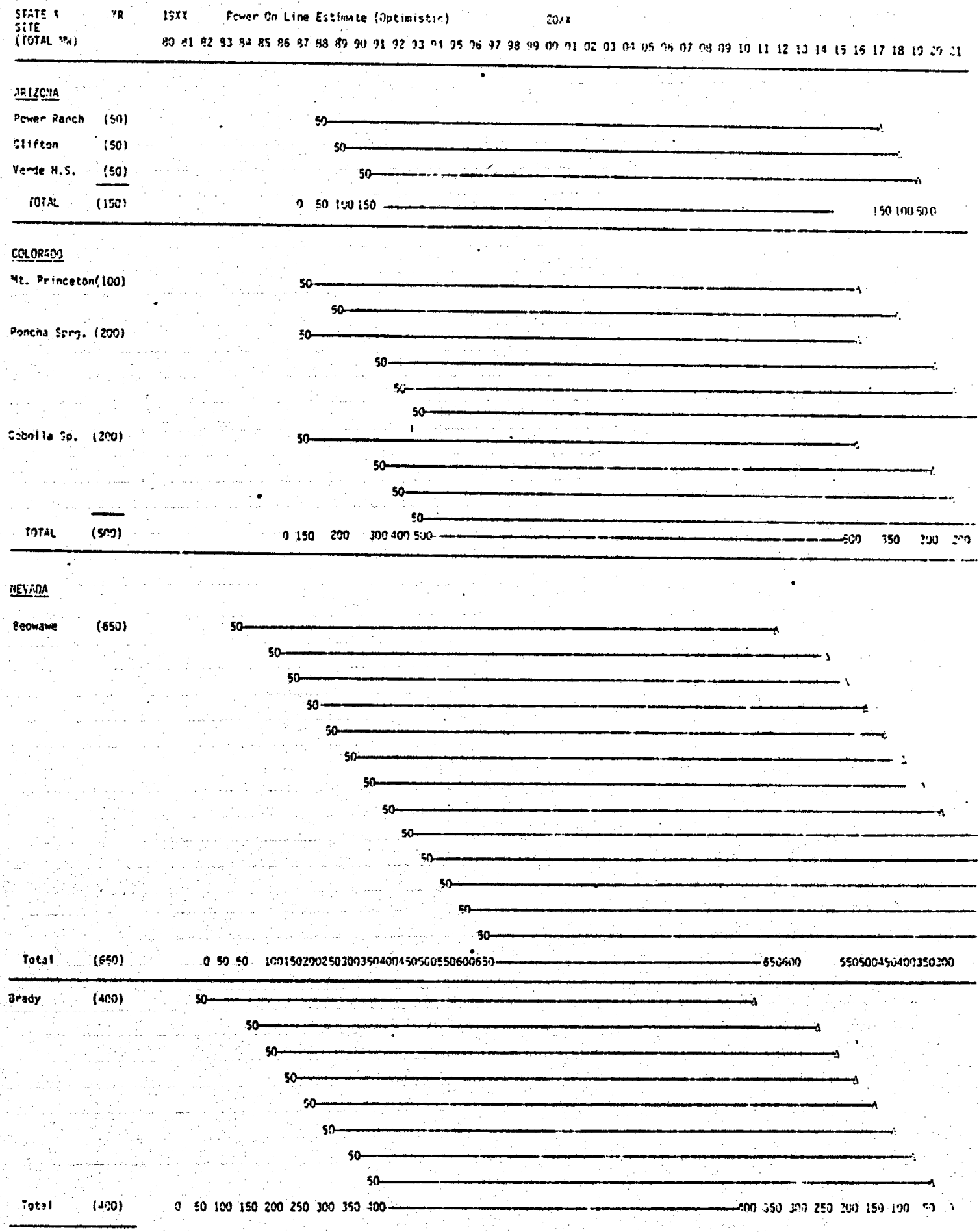

Figure 10 


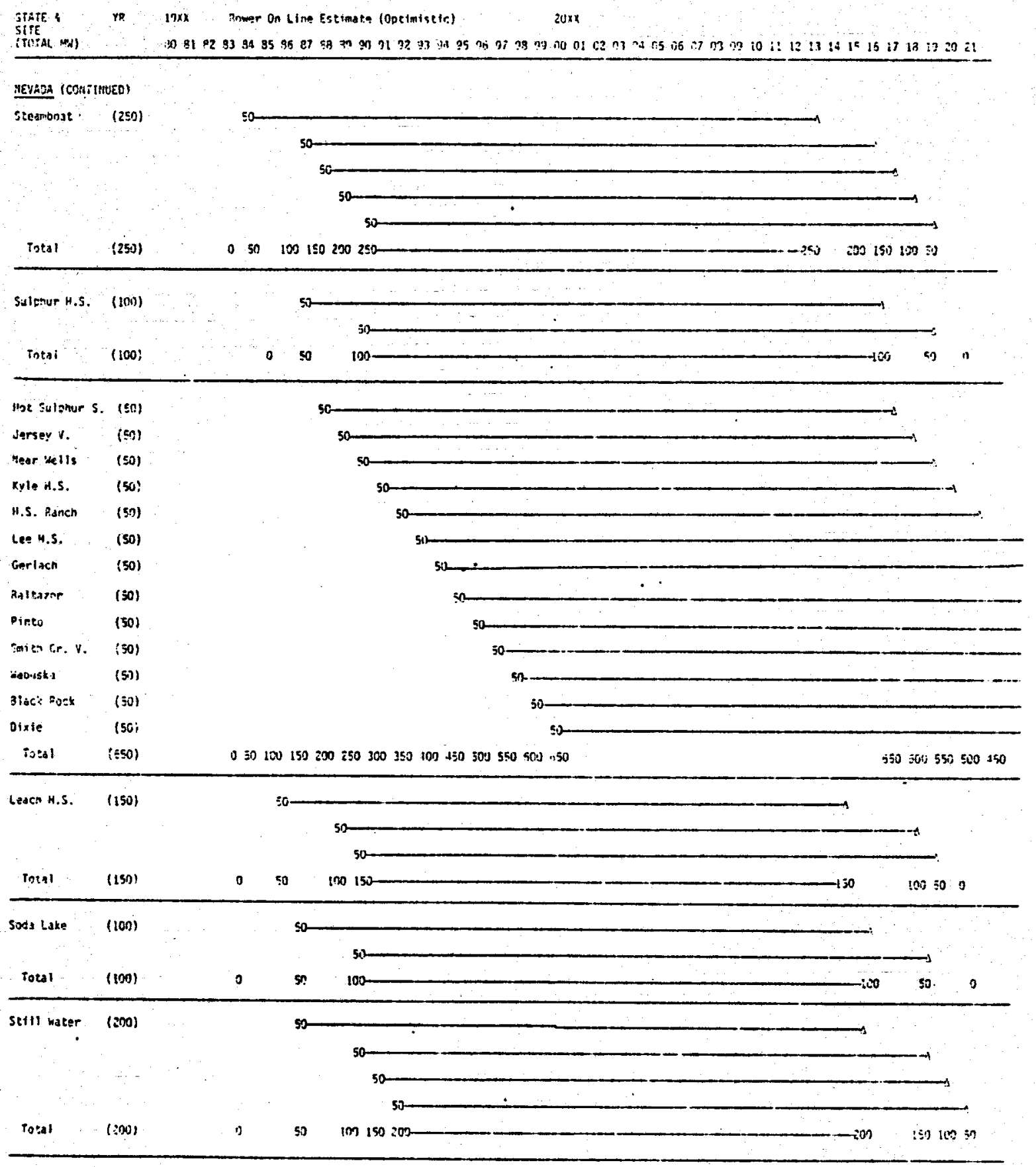

Figure 10 (Contd) 


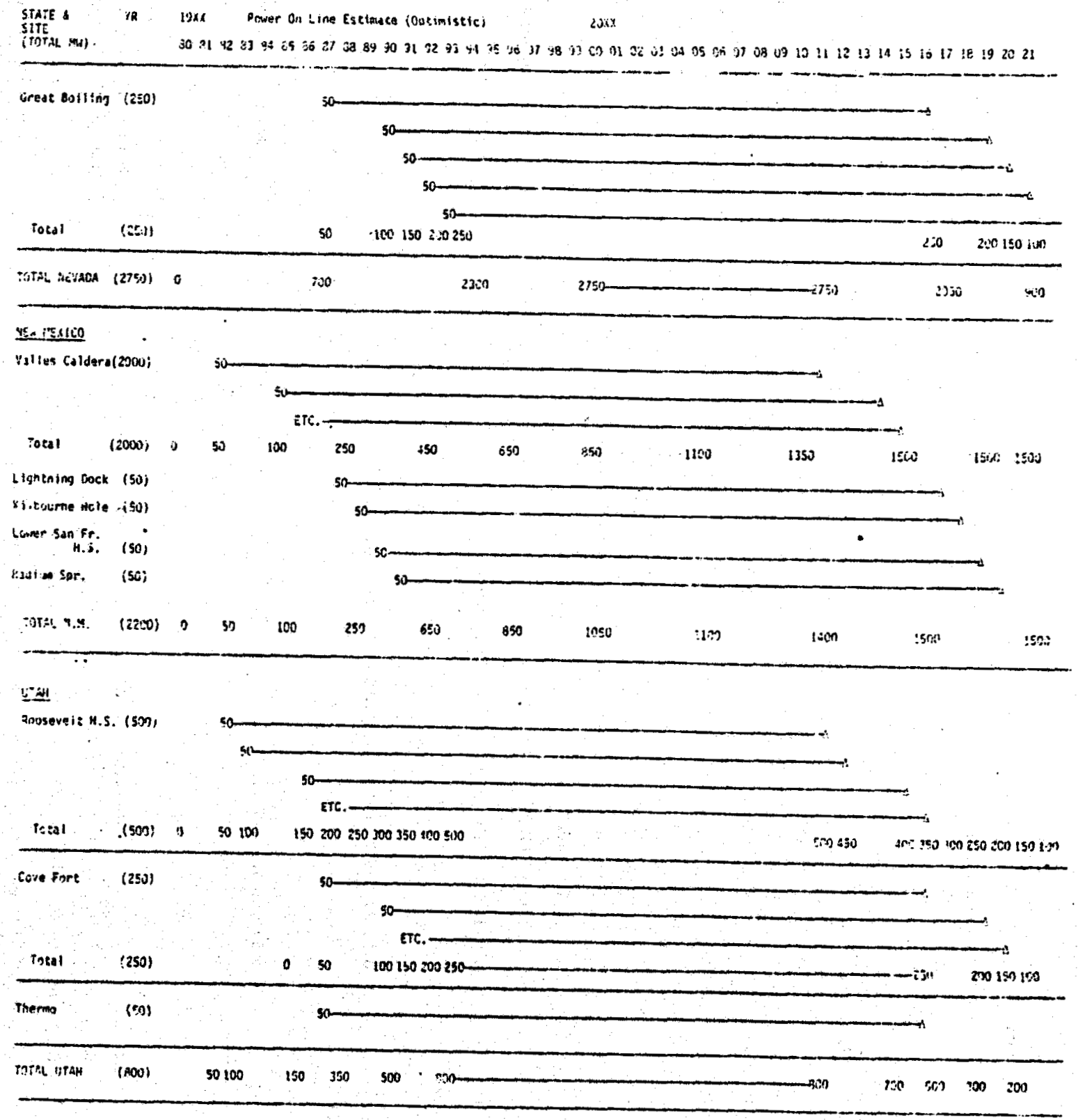

Figure 10 (contd) 


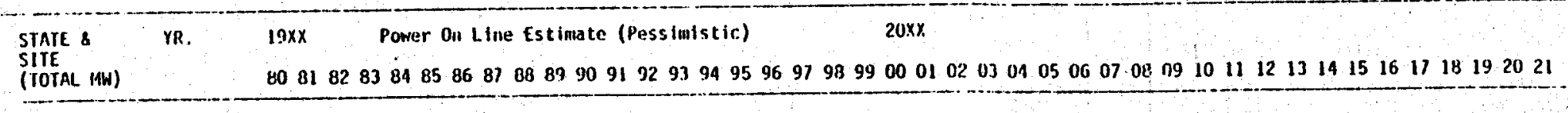

- -

ARIZONA

None

COLORAOO

Ht. Princeton (100)

Poncha Springs (100)

Total Colorado (200)

O $50 \quad 505050100$

505050

O 50.5050100

$-1005050$

050100100100200

200150100100

MFYADA

Beowawe (600)

Bridy (300)

Steambuats (150)

Total Mevada (1050)

5050501001502002503003504004505005506100

600550550550500450400350 D 505050100150200250300

$30025025025020015010050 \quad 0 \quad 0$

05050100150 $15010010050 \quad 0 \quad 0 \quad 0$

O 505010020025010055065070075080085090095010001050

10501000950850800650500400350

NEE IEXXICO.

valles Caldera (1900)

o $505050100150200250300350400450500550600650700750800850900350 \ldots \ldots \ldots \ldots \ldots$

UINI

Roosevelt II.S. (3nit)

O 50$) 50100150200250300$

-300250250200150100 50 $0 \quad 0$

REGIOH

Arizoila

Calorado

Nevada

New Hexicn

Utah

50 100150200250300

TOTAL.

(3150)

Figure 11 


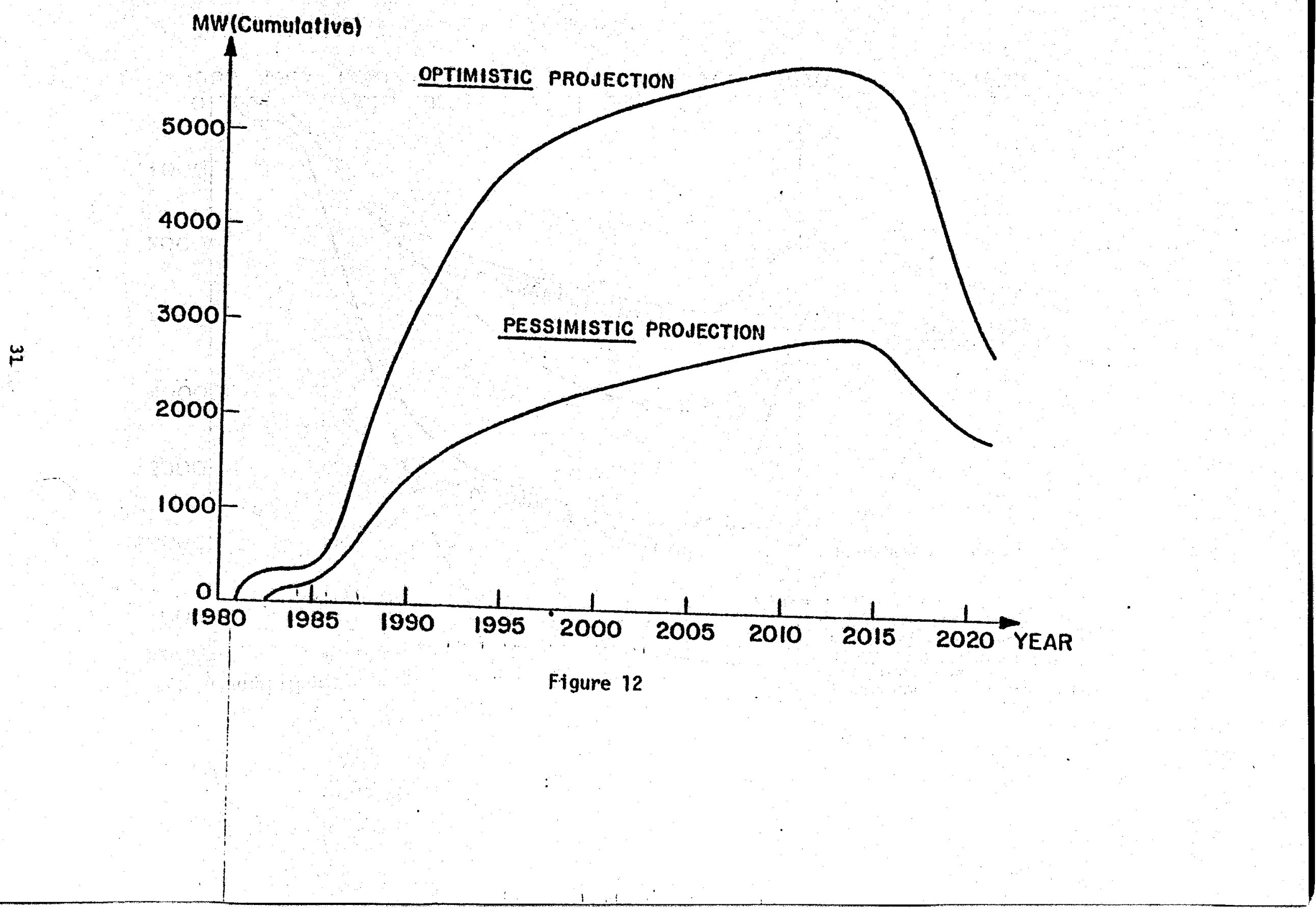




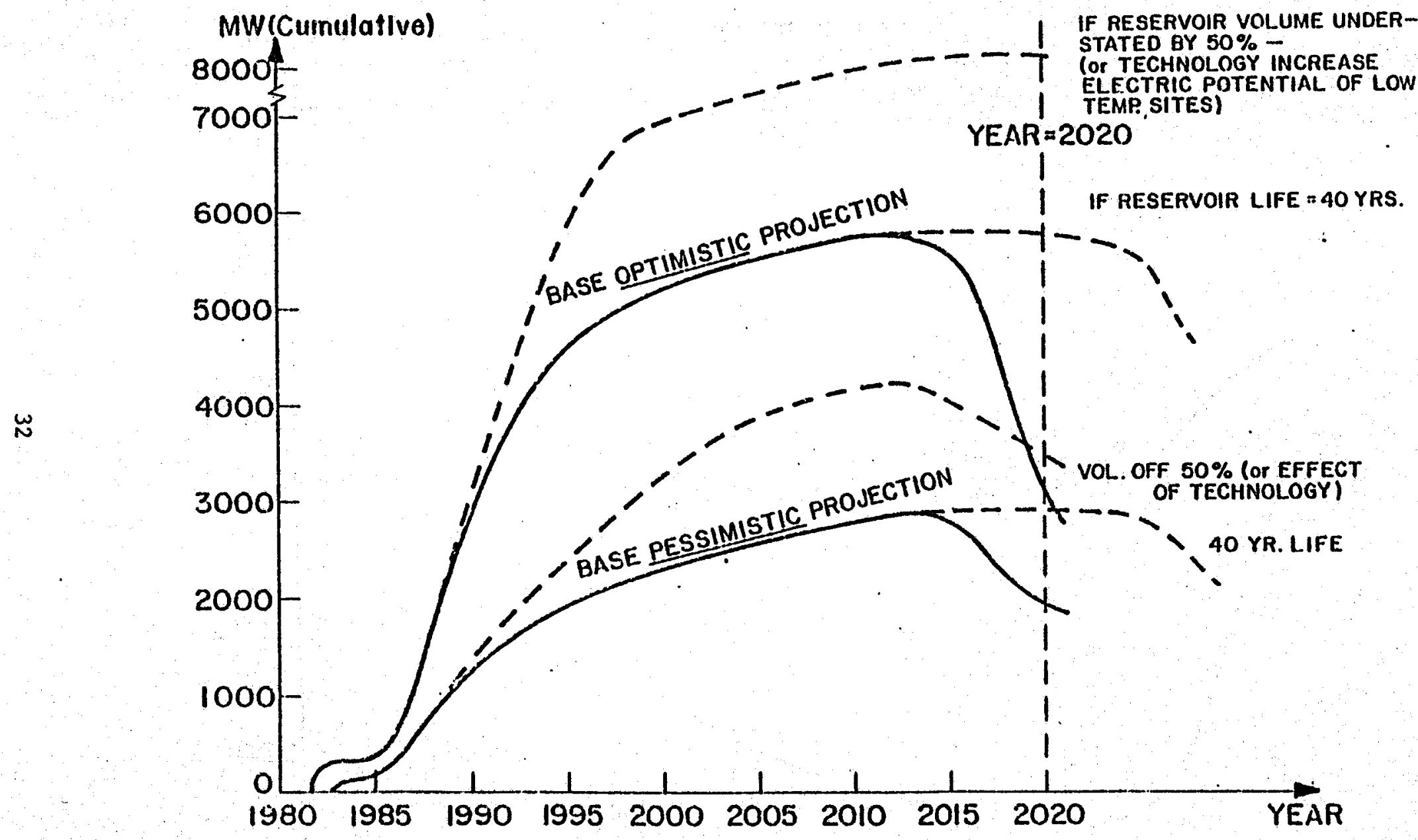

Figure 13 
GIRORA NON-ELECTRIC: SENSITIVITY ANALYSIS

THE MODEL

GIRORA NON-ELECTRIC is an internal rate of return model which is similar (except in one respect) from a methodological perspective to the Geothermal Electric model. An internal rate of return is calculated for a perspective geothermal energy producer for each technologically feasible geothermal site. The internal rate of return (IRR) is the discount rate which equates the net present value of all net revenues with the net present values of all investment costs.

GIRORA NON-ELECTRIC is simpler in one respect, however, than its counterpart GIRORA ELECTRIC. For the latter, geothermal energy is produced (the Geothermal Production Sector) and sold to an electricity producer (the Electric Utility Sector), from which the final product is sold to consumers; in GIRORA NON-ELECTRIC, the geothermal fluid is sold directly from the producer (the Geothermal Froduction Sector) to the ultimate consumer (the Consumption Sector). Thus, only production sector exists in the nonelectric model. However, the role of the Consumption Sector is precisely analogous to the role of the Utility Sector in the electric model:

The discounted cash flow model may be represented as:

$$
\sum_{t=0}^{T}\left(\text { INVESTMENT) } e^{-R t}=\sum_{t=1}^{T}\left(\text { NET INCOME) } e^{-R t}\right.\right.
$$

Investment = Investment expenditures incurred by the geothermal producer,

Net Income $=$ Net income received by the geothermal producer,

$T=\quad$ The life of a resource.

$R=\quad$ The internal rate of return. 
The primary modeling effort consists of estimating the net revenues earned and the investment costs incurred by the energy producers. The calculations for each case are summarized briefly below.

\section{Consumption Sector}

The revenues earned by the geothermal energy producer are the product of the price of geothermal fluid times the quantity demanded by the consumption sector. The price of geothermal energy is assumed equal to the energy equivalent price of alternative fuels used for space heating. The quantity demanded is assumed to be a function of the space heating demand for each potential district heating unit (comunity); in turn, the space heating demand is estimable given resource temperature, population, housing construction, and degree day data, all of which are available.

- Conceptually then, the consumption sector in the non-electric model plays the same role as the utility production sector in the electric modelit provides the market for and generates the revenues of the geothermal energy producer. While the investment costs are incurred by the geothermal producer, gross revenues clearly originate with the final consumers. Net revenues are then determined by subtracting from gross revenues all variable expenses; including operating costs, debt cost, taxes and royalties.

\section{Geothermal Production Sector}

The present values of net revenues to be earned throughout the life of a resource are balanced against similarly discounted drilling investment (DNV), leasing investment (LNV), plant investment (PLV), and interest during construction (IDC) costs. The total of these investment costs is estimated for each of the years of the resource life and then discounted approprlately. 
Drilling investment consists of the cost of drilling production and injection wells. This cost expense is calculated as the product of drilling cost per well times the number of wells required to fulfill the consumption sector demand assuming a standard spacing of wells. The number of required wells can be calculated from the resource temperature, the resource flow rate, and the peak heat demand of the consumption sector.

Leasing Investment is the cost of obtaining leases and drilling rights for exploratory and production wells. This cost is estimated as the sum of the required acreage per production well times the cost per acre plus the required acreage for injection wells times the cost per acre.

- Plant investment is the sum of transmission cost plus distribution cost. Transmission cost is the cost of transporting the geothermal brine from the point of production to the district heating unit; it is computed as the product of piping cost per mile times distance in miles. Distribution cost is the cost of transporting the geothermal fluid from the point of transmission to the point of consumption. This expense is functionally determined on the basis of the number of dwelling units and an estimated cost per dwelling unit.

Finally, interest costs incurred prior to geothermal energy production may be capitalized, and they are therefore considered an element of investment cost.

\section{The Internal Rate of Return}

Multiplying the total investment outlay times the debt/equity ratio of the geothermal producer, we find the total geothermal-producer, equity capital. Equating this investment to net revenues we have 


$$
\begin{aligned}
& \text { [Producer Investment - (total revenue - debt cost - operating cost - } \\
& \text { property taxes - issuance taxes - royalties)] } e^{-R t}=0 .
\end{aligned}
$$

$R$ is the internal rate of return which is computed by the "Newton-Raphson . Technique of Approximation to the Root of a Polynomial."

\section{SENSITIVITY ANALYSIS}

The purpose of this research is to ascertain the sensitivity of the estimated internal rate of return to selected input parameters. The major application of the results is the evaluation of public polfcy potential for influencing the profitability of investment in geothermal energy. Three distinct classes of input parameters are considered.

The first of these includes the physical features of the resource itself. Of primary importance here are the impacts upon the IRR of a change in the resource temperature, the distance to the demand site, the value of demand (population of the heating district), and the flow rate of the resource. The second class of input parameters considered consists of policy parameters. These are input parameters which have been previously employed as a means of altering the financial desirability resource of investment through public policy. Included here are variations in the royalty rate, the investment tax credit, the depletion allowance, the bond rate of the producer, and the price of competing fuels. Finally, an input parameter which is determined institutionally and clearly impacts upon the IRR is the load factor. The possibility of multiple uses presents a clear potential for inducing the fullest possible load factor, and the impacts of this factor are unknown. 


\section{The Base Case}

Initially, a "base case" was chosen which would provide a benchmark, against which subsequent findings may be contrasted. As specific input parameters are altered, charges in $\mathrm{R}$ from the base case then provide some estimate of the sensitivity of the IRR to the selected input parameter. of primary interest in this analysis, then, are the relative changes in $R$ from the base case scenario and not the absolute values. "Base case" values which were initially assumed for selected model parameters, are presented in Table 10.

The Internal rate of return for this "typical" case is $11.5 \%$. That is, the discount rate which w1ll equate the net present values of net revenues and investment costs throughout the project life is $11.5 \%$. The higher this value of $R$, all other things equal, the more financially profitable a geothermal resource will be. In the following pages, the significance of selected input parameters in infiuencing the internal rate of return will be ascertained.

The first set of input parameters to be studied in detail are the physical characteristics of the resource itself. These factors w1ll clearly vary from one site to another, and this variation will determine the expected profitability of the resource. A preliminary appraisal of the importance of each of these in determining the internal rate of return may be inferred from the following sensitivity analysis.

\section{Sensitivity Estimation}

Consider first the temperature of the resource. In general, the hotter the water, the higher the rate of return will be. In the base case example, the temperature was assumed to be $300^{\circ} \mathrm{F}$, the upper limit which is likely to be harnessed for direct applications. The temperature was then varied from 


\begin{tabular}{|l|c|}
\hline \multicolumn{1}{|c|}{ Variable } & Value \\
\hline Load Factor & 0.75 \\
Base Price of Energy & $\$ 8 / 10^{6}$ \\
Rate of Escalation of Base Price & 0.05 \\
Debt - Equity Ratio & $3 / 7$ \\
Bond Rate & 0.085 \\
Investment Tax Credit & 0.16 \\
Income Tax Rate & 0.50 \\
Flow Rate & $400,0001 \mathrm{bs} / \mathrm{hr}$ \\
Temperature & $300^{\circ} \mathrm{F}$ \\
Royalty Rate & 0.1 \\
Depletion Allowance & 0.0 \\
Population & 10,000 \\
Distance & $10 \mathrm{miles}$ \\
\hline ESTIMATED R & $11.5 \%$ \\
\hline
\end{tabular}

Table 10. Base Case Values 
$200^{\circ} \mathrm{F}$ to $300^{\circ} \mathrm{F}$ to determine its impact upon R. This incorporates most (but not all) of the temperatures that will in all probability be considered for development.

Figure 14 portrays the estimated impacts of temperature changes upon $R$. At $200^{\circ} \mathrm{F}$ the rate of return is $8 \%$, and at a peak temperature of $300^{\circ} \mathrm{F}$ the rate of return is $11.4 \%$. Thus an increase of $50 \%$ in a $200^{\circ} \mathrm{F}$ temperature raises the rate of return by $42.5 \%$. As one might reasonably expect, given the importance of temperature in determining investment costs, the temperature of the resources proves to be one of the most important of all of the variables considered in means of determining $R$.

The population of the space heating market to be used by a geothermal resource is another important site feature. All other things equal, the greater the population, the greater will be the rate of return, and vice versa. Most of the population areas likely to be found in the Southwest fall within the 5,000-30,000 continuum; and accordingly, that is the range of populations considered.

Figure 14illustrates the changes in $R$ which result from alternative market populations. For 5,000 users, the rate of return is $10.4 \%$; and for 30,000 users the rate of return rises to $12.7 \%$. A six-fold increase in population therefore raises $\mathrm{R}$ by $22 \%$. Compared to temperature changes at least, differences in the market size exert a lesser but still notable impact upon the rate of return.

The third physical site characteristic which is assumed apriori to exert an influence upon the rate of return is the distance between the resource site and the point of consumption. The farther removed the resource site is from the market, the greater the transmission costs will be and the lower the rate of return will be. The impacts of altering this distance factor 


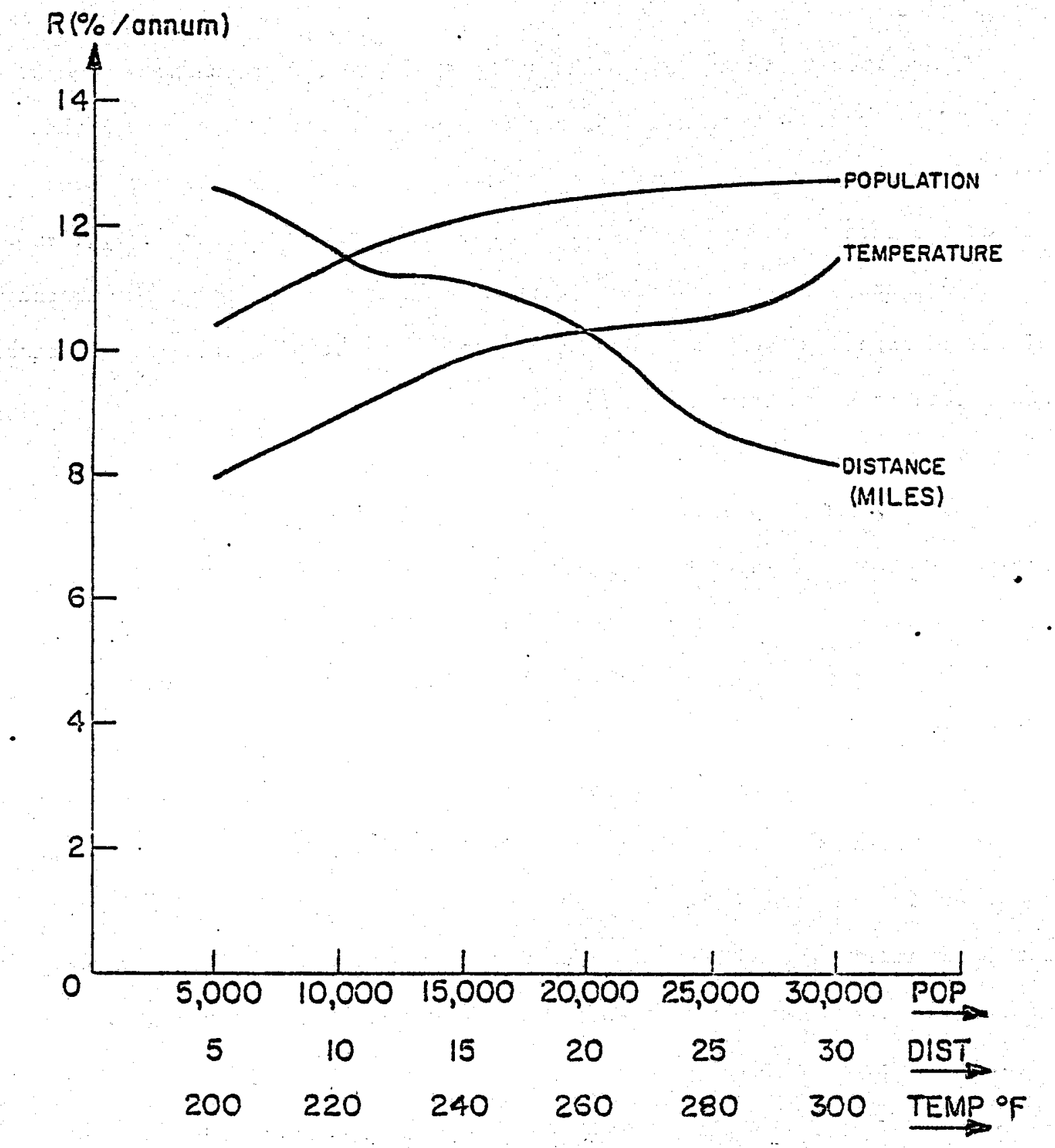

Figure 14. Sensitivity of the Rate-of-Return to Variations in Temperature, Distance and Population. 
are depicted in Figure 14. These findings reveal that distance is an extremely important consideration in the rate of return earned. As the hypothetical distance increases from 5 miles to 30 miles, the rate of return declines rapidly from $12.6 \%$ to $8.1 \%$. This is a reduction of $35.7 \%$ for an increase of 25 miles. In the southwestern United States where population centers are often widely scattered, 25 miles is an extremely short distance. Accordingly, the distance factor should prove to be a highly significant determinant of the rate of return.

The final physical resource characteristic which was considered is the flow rate (FR) of the resource. In the base case, the flow rate was assumed to be $400,000 \mathrm{lbs} / \mathrm{hr}$; the range of flow rates proposed lies between 200,000 and $450,000 \mathrm{lbs} / \mathrm{hr}$. Figure 15 summarizes the impacts of various flow rates illustrated in rate of return-temperature two space. Variations in the flow rates generate a rather broad shifting of $R$ for all temperatures. For. example, at $300^{\circ} \mathrm{F}$, the temperature in the base case, the rate of return rises from $9.1 \%$ at $200,000 \mathrm{lbs} / \mathrm{hr}$ to $12.3 \%$ at $450,000 \mathrm{lbs} / \mathrm{hr}$, a $35 \%$ rise. This degree of sensitivity indicates that differences in flow rates from one geothermal site to another will influence $R$, and that site with the highest FR will, all other things equal, be developed first.

Having evaluated the importance of some major physical characteristics of the geothermal resource, we turn next to the consideration of selected policy variables. Relying again upon the base case analysis, the values of selected policy variables have been changed, one at a time. The resulting changes in $R$ from the base case $R(11.5 \%)$ are highly informative.

The first policy variable considered was the depletion allowance $(Z)$. The depletion allowance was 0 in the base case, and it was assigned successively 


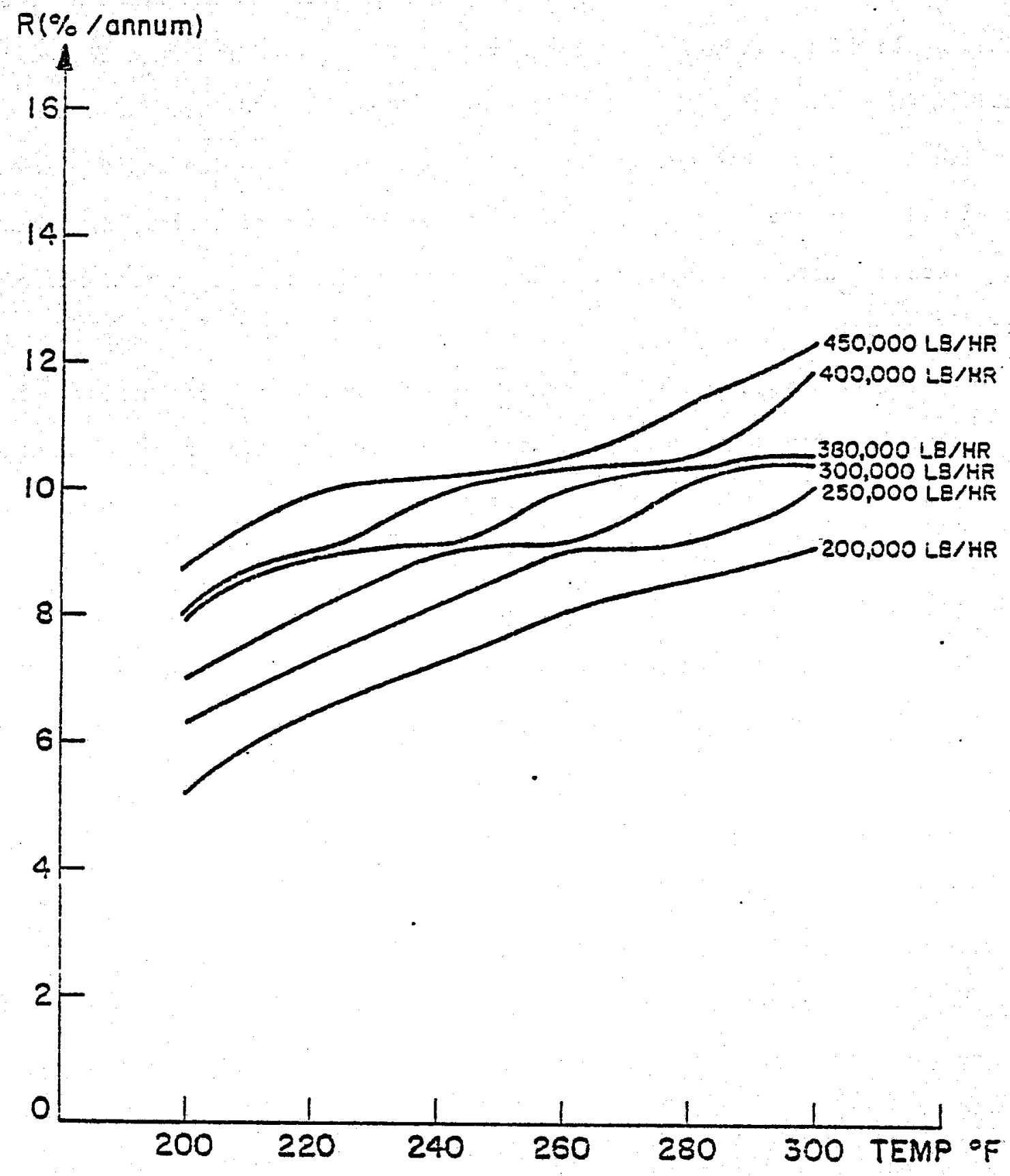

Figure 15. Sensitivity of Rate of Return to Flow Rate. 
larger values of .11 and .22. The resulting impacts upon $R$ are illustrated in Figure 16. At all temperatures, the increase in $R$ is roughly .6 percentage points ( $a 7.59 \%$ increase) when $\mathrm{Z}$ is increased from 0 to .11 ; and $\mathrm{R}$ rises by 1.4 points (a $17.7 \%$ Increase) when $Z$ is increased from 0 to .22 . At a temperature of $300^{\circ} \mathrm{F}$, then, the internal rate of return is $11.9 \%$ when $\mathrm{Z}=0$, $12.5 \%$ when $z=11$, and $13.3 \%$ when $z=.22$.

Consider next the sensitivity of the internal rate of return to changes in the investment tax credit (CRRT). The init1al, base case value of CRRT was 0.16 . As the value of the investment tax credit is increased or decreased, $R$ should rise or fall, Alternate values of tax credits were specified (in increments of .04 ) from $C R R T=0.0$ through 0.2 . The resulting changes in $R$. at various temperatures are illustrated in Figure 17. The variations are clearly miniscule. The rate of return rises a scant $0.2 \%$ (from 7.8 to 8.0 percent) as the investment tax credit increased from 0 to 0.2 . As a policy tool, the tax credit promises only limited effectiveness.

Another policy tool which has been employed in the natural gas and ofl Industries is the royalty rate $(\lambda)$. As the royalty rate is increased or decreased, the profitability of geothermal energy will fall or rise. The base case value of $\lambda$ was 0.1 , and this value was reduced to 0.0 in the sensitivity analysis to evaluate the policy impacts. As Figure 18 illustrates, a very moderate impact upon $R$ is evident. At all temperatures, $\lambda=0.0$ raises the rate of return by 0.7 percentage points. Thus, at a temperature of $300^{\circ} \mathrm{F}, \mathrm{R}$ rices from $11.8 \%$ to $12.5 \%$; a $5.9 \%$ increase.

The fourth policy variable which was considered is the bond rate (BR) paid by the geothermal producer. Efforts such as loan guarantee programs effectively reduce the risk of financial default, thereby reducing interest 


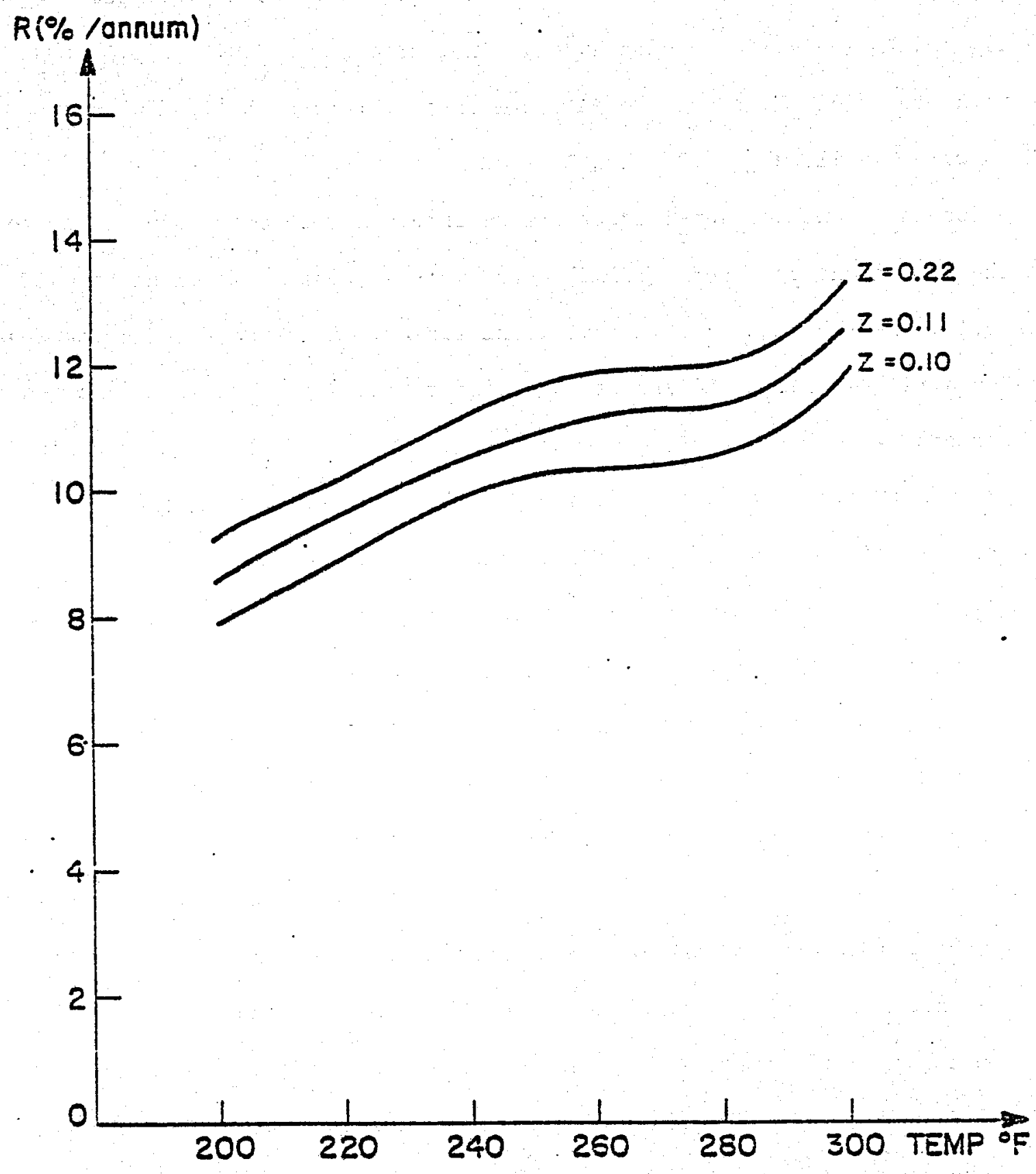

Figure 16. Sensitivity of Rate of Return to Depletion Allowance 


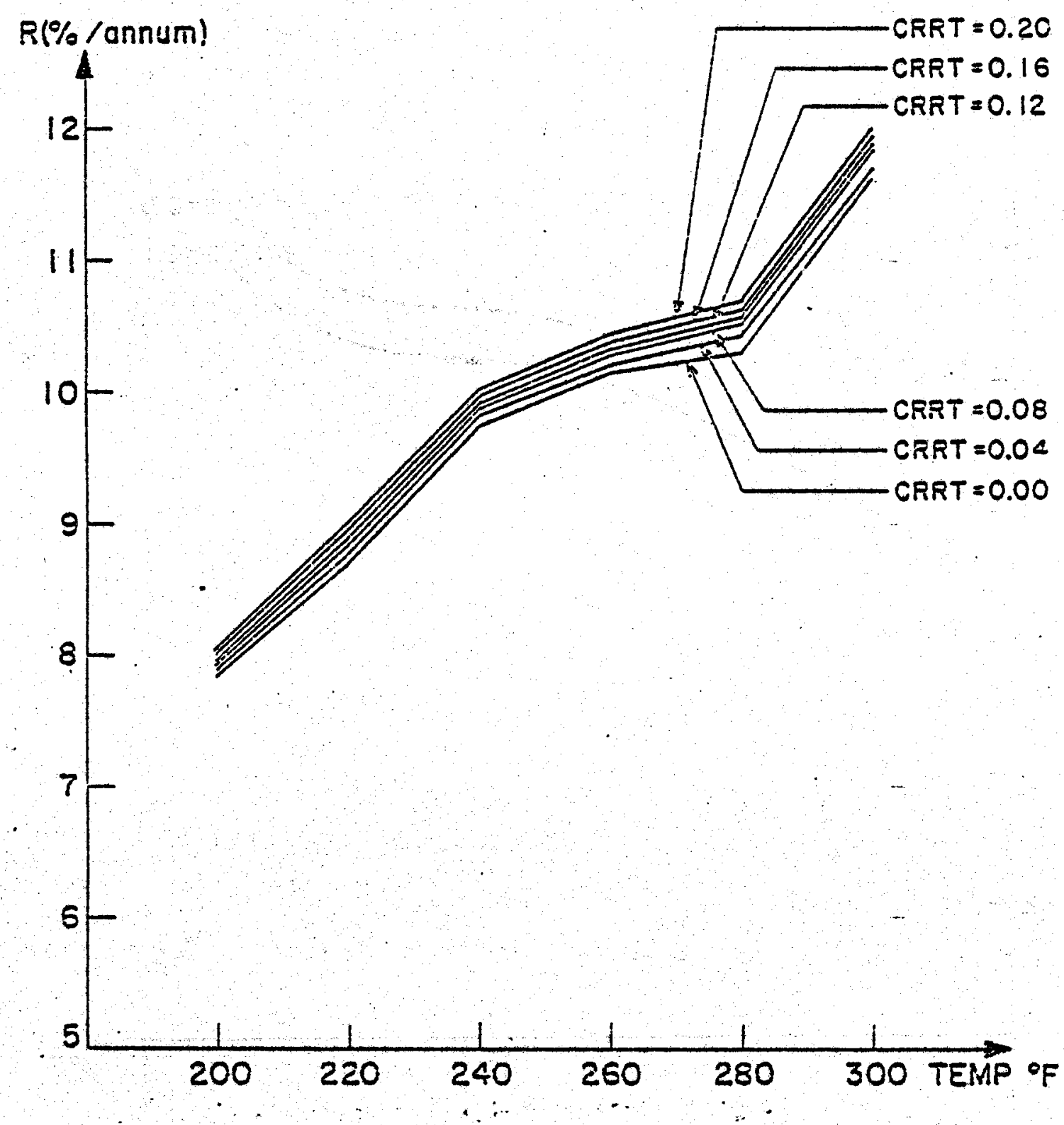

Figure 17. Sensitivity of Rate of Return to Investment Tax Credit 


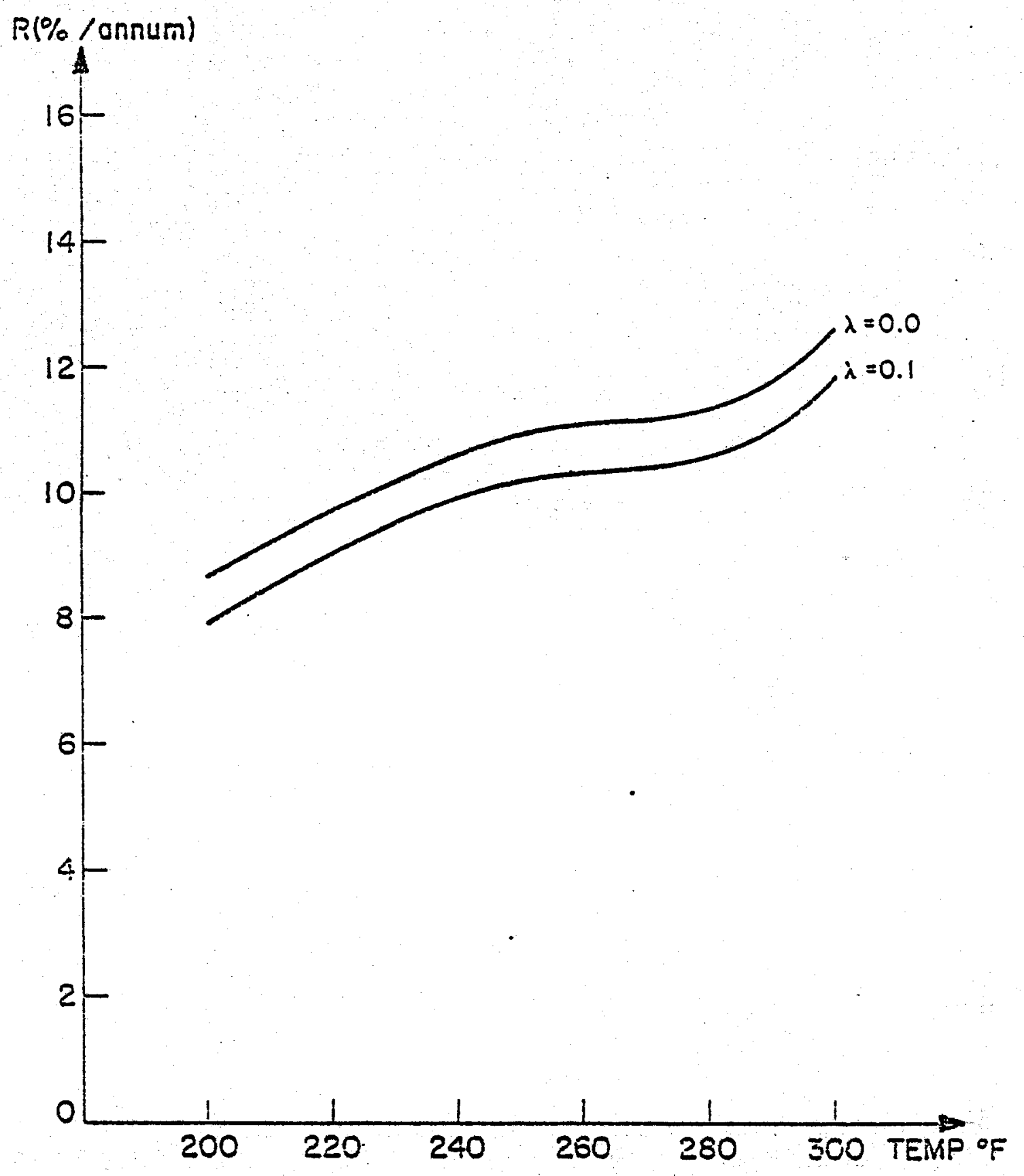

Figure 18. Sensitivity of Rate of Return to Royalty Rate. 
charges on bonded indebtedness. The estimated impacts of various values of BR upon the rate of ceturn are illustrated in Figure 19. As the bond rate falls from 8.5 to $6.5 \%$, the improvement in $R$ is only .8 percentage points. At $300^{\circ} \mathrm{F}$, $\mathrm{K}$ rises from 11.9 to 12.7 percent. The internal rate of return is only very moderately sensitive to charges in the bond rate.

The last remalning policy variable is the price of energy. As gas and electricity prices are allowed to rise, the rate of return from geothermal energy will also rise. In Figure 20, natural gas prices are varied between $\$ 5$ and $\$ 10 / 10^{6} \mathrm{Btu} / \mathrm{hr}$, compared with the base case price of $\$ 8 / 10^{6} \mathrm{Btw} / \mathrm{hr}$. The impacts upon $R$ are substantial as expected. For example, at $300^{\circ} \mathrm{F}$, raising the price from $\$ 5$ to $\$ 10$ increases $R$ from 8.2 to $13.6 \%$; an increase of $65.8 \%$. Alternatively, a price increase from $\$ 5$ to just $\$ 6$ raises $R$ from 8.2 to $9.4 \%$; a $15 \%$ rise. Quite clearly, potential fuel price increases exert substantial impacts upon $R$ more so than any of the other policy variables considered.

There is one remaining model parameter which, if it can be effectively controlled, can exert a potentlally notable impact upon the rate of return. This is the load factor (LF), defined as the proportion of full design capacity at which, on average, the production and distribution system operates. All other things equal, the greater the load factor, the greater $R$ will be, and vice versa.

Numerous possibilities do, in fact, exist for increasing load factors. These will be collectively referred to as co-generation, the practice of harnessing a geothermal resource for multiple uses. The impacts of co-generation have been simulated by ranging the load factor from .5 to .8 . The results are pictured in Figure 21 At $300^{\circ} \mathrm{F}$, raising the load factor from 


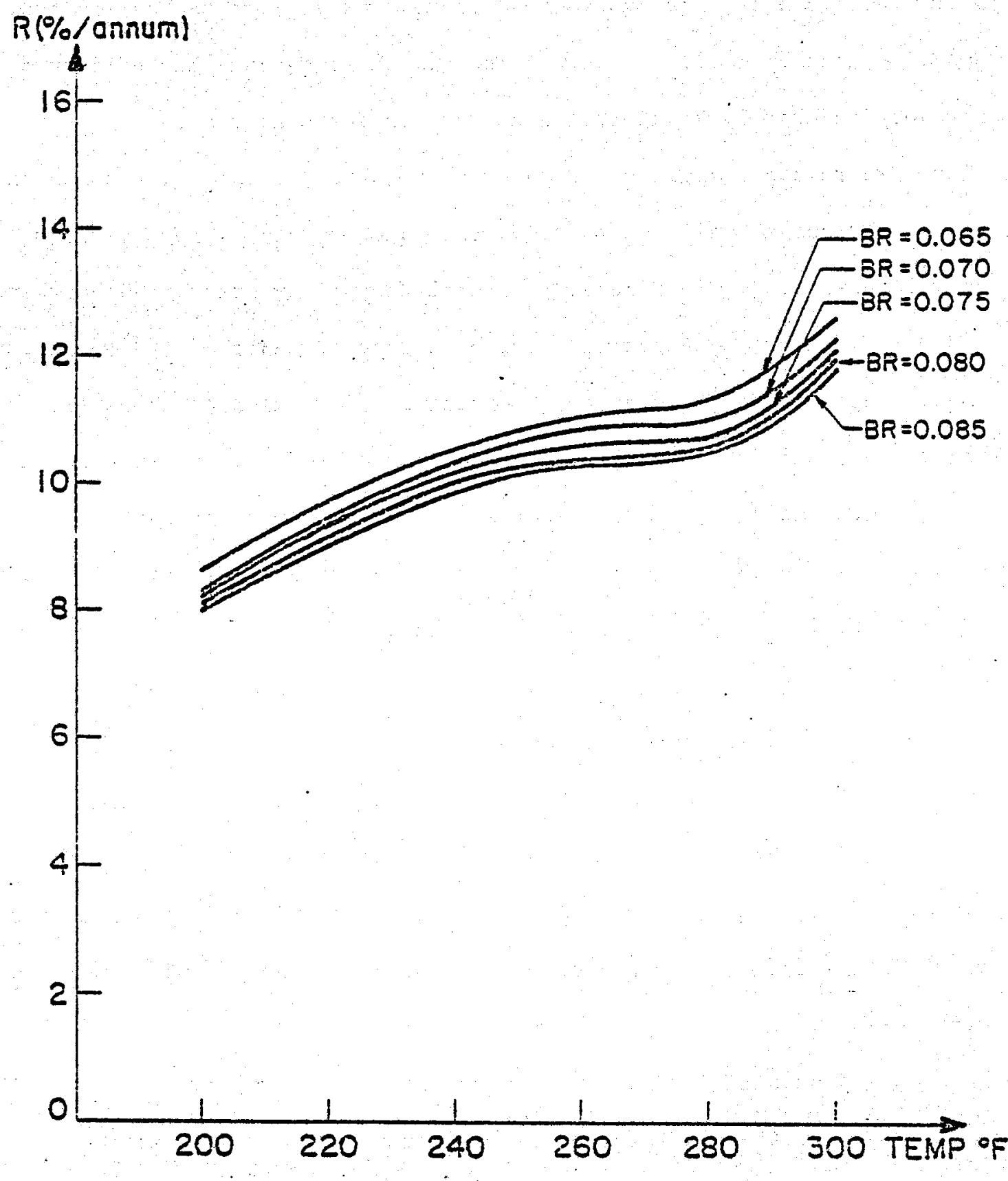

Figure 19. Sensitivity of Rate of Return to Bond Rate 


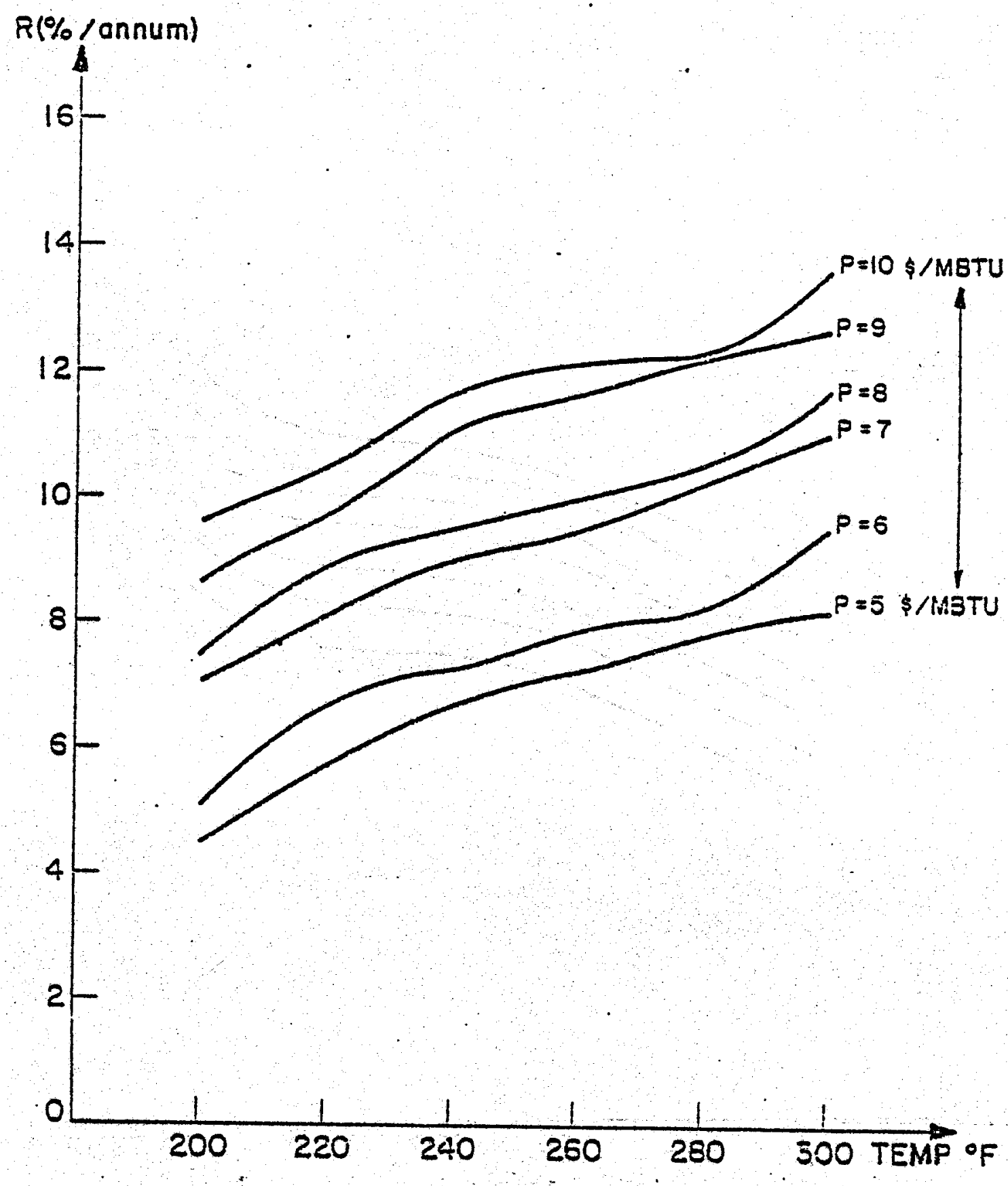

Figure 20. Sensitivity of Rate of Return to Energy Price of Alternative Energy. 


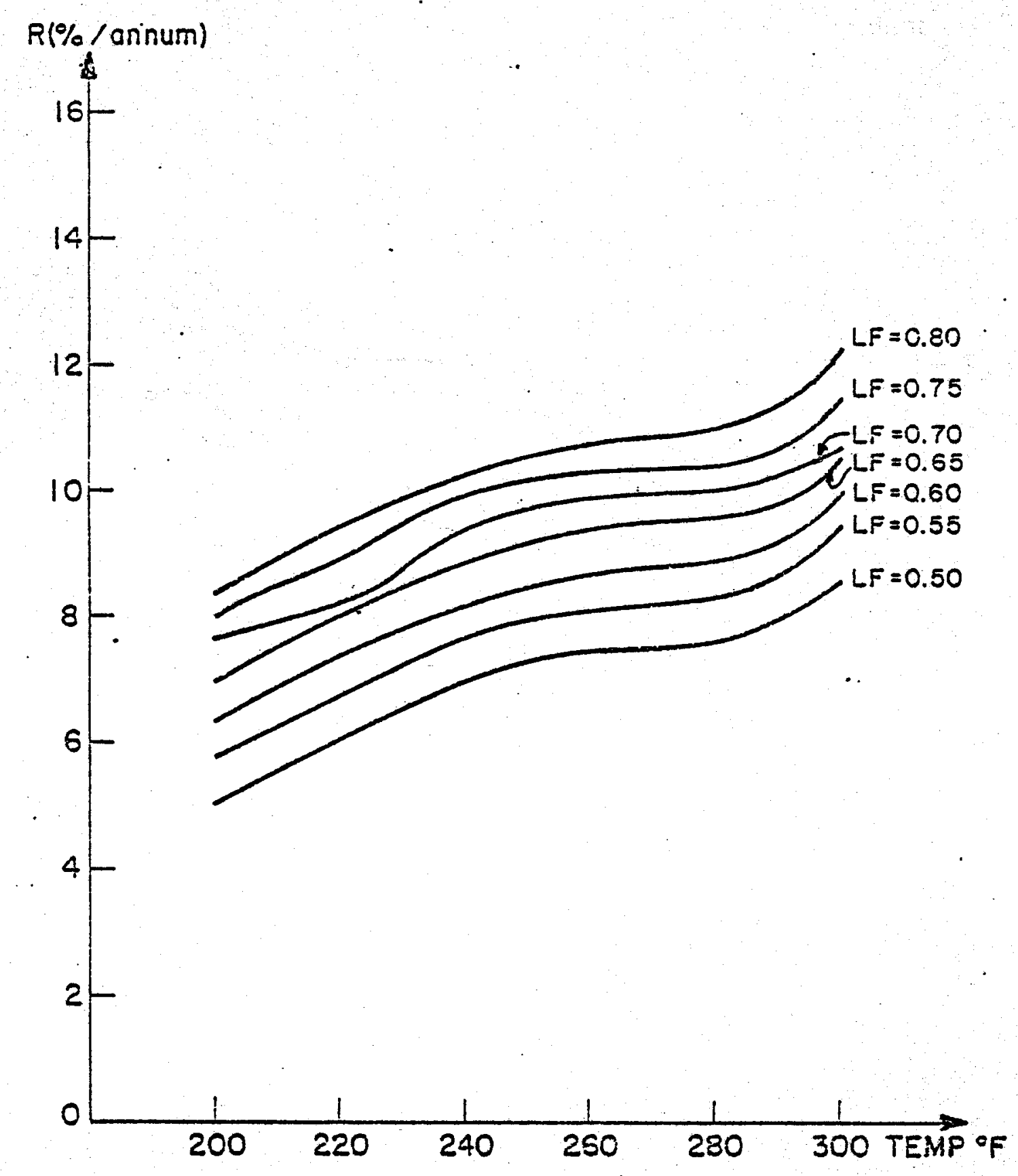

F1gure 2i. Sensitivity of Rate of Return to Load Factor 
.5 to .8 increases $R$ from $8.6 \%$ to $12.3 \%$, an attractive increase of $43 \%$. At all temperatures, $R$ rises by roughly 3.5 percentage points. Evidently, the payof to efforts at issuing high-load factors are sizable.

A summary of all of the results of the sensitivity analyses is presented in Table 11 .

\section{VARIANCE ANALYSIS}

There are a number of ways in which the results of the sensitivity analysis may be productively employed. One of the most informative is the formulation of specific market scenarios and the comparison of projected rates of return for each scenario. An example of the kind of results to be gained from such an approach is presented here. The results of an "optimistic" market scenario are contrasted with those for a "pessimistic scenario". The range of rates of return serves to delineate the market possibilities for geothermal energy development for two sets of circumstances.

The approach employed to specify a pessimistic and an optimistic scenario is as follows. All of the (four) physical, site-specific characteristics of the resource are assumed constant. These include temperature, flow rate, distance to demand, and demand volume. All of the variables which are pollcy variables as well as the institutional variable are altered over the ranges considered in the sensitivity analysis above. These factors include the royalty rate, depletion allowance, energy price, tax credit, bond rate, and load factor.

The results of the scenario forecasts may then be interpreted as follows. For any given resource site, 1.e., with physical input parameters held constant, the range of return reflects the potential impact of coordinated policy efforts and institutional actions in influencing $R$. More succinctly, 
Temperature $=300^{\circ} \mathrm{F}$ "Base Case" Values

\begin{tabular}{|l|c|c|c|}
\hline Variable & \multicolumn{1}{|c|}{ Range } & $\Delta \mathrm{R} / \mathrm{R}$ & Range of R \\
\hline Temperature & $300-200^{\circ} \mathrm{F}$ & $-42.5 \%$ & $11.4-8.0 \%$ \\
Flow Rate & $200,000-450,0001 \mathrm{~b} / \mathrm{hr}$ & $+35.0 \%$ & $9.1-12.3 \%$ \\
Distance & $5-30$ miles & $-35.7 \%$ & $12.6-8.1 \%$ \\
Population & $5,000-30,000$ & $+22 \%$ & $10.4-12.7 \%$ \\
Royalty & $10 \%-0 \%$ & $+5.9 \%$ & $11.8-12.5 \%$ \\
Depletion & $0-22 \%$ & $+11.8 \%$ & $11.9-13.3 \%$ \\
Tax Credit & $0-20 \%$ & $+.02 \%$ & $.7 .8-8.0 \%$ \\
Energy Price & $5-10 \$ / 10^{6}$ Btu & $+65.8 \%$ & $8.2-13.6 \%$ \\
Bond Rate & $6.5 \%-8.5 \%$ & $+.8 \%$ & $11.9-12.7 \%$ \\
Load Factor & $0.5-0.8$ & $+43 \%$ & $8.6-2.3 \%$ \\
\hline
\end{tabular}

Table 11. Sumary of Sensitivity Analyses 
the results tell us what we can and cannot do in a clearly defined policy sense to influence the profitability of geothermal energy development for district heating. purposes.

The values of the policy and institutional variables that have been employed are presented in Table 12. The values of the resulting rates of return for each scenario at different temperatures are illustrated in Figure 22. The most inmediate impression is of a very large spread of potential returns between the two scenarios. At a temperature of $200^{\circ} \mathrm{F}$, the pessimistic rate of return is $1.6 \%$, hardly an attractive investment; in the optimistic scenario, the rate of return is a more attractive $12.8 \%$. Similarly, at $300^{\circ} \mathrm{F}$, the difference between $R$ values is 12.7 percentage points, $5 \%$ versus $17.7 \%$. At this juncture, therefore, it seems evident that an effective combination of policy initiatives can effectively alter the internal rate of. return from relatively low to relatively higher levels.

Recall that in the two scenarios considered above, the features of the resource site have been held constant. As these are allowed to vary (that is, as we consider more or less attractive sites), the rate of return functions will shift upwards or downwards. Thus, as the temperature flow rate or popu-. lation rises and as the distance factor falls, both rate of return functions shift upwards; and as the physical characteristics change in the opposite direction, the rate of return functions fall. 


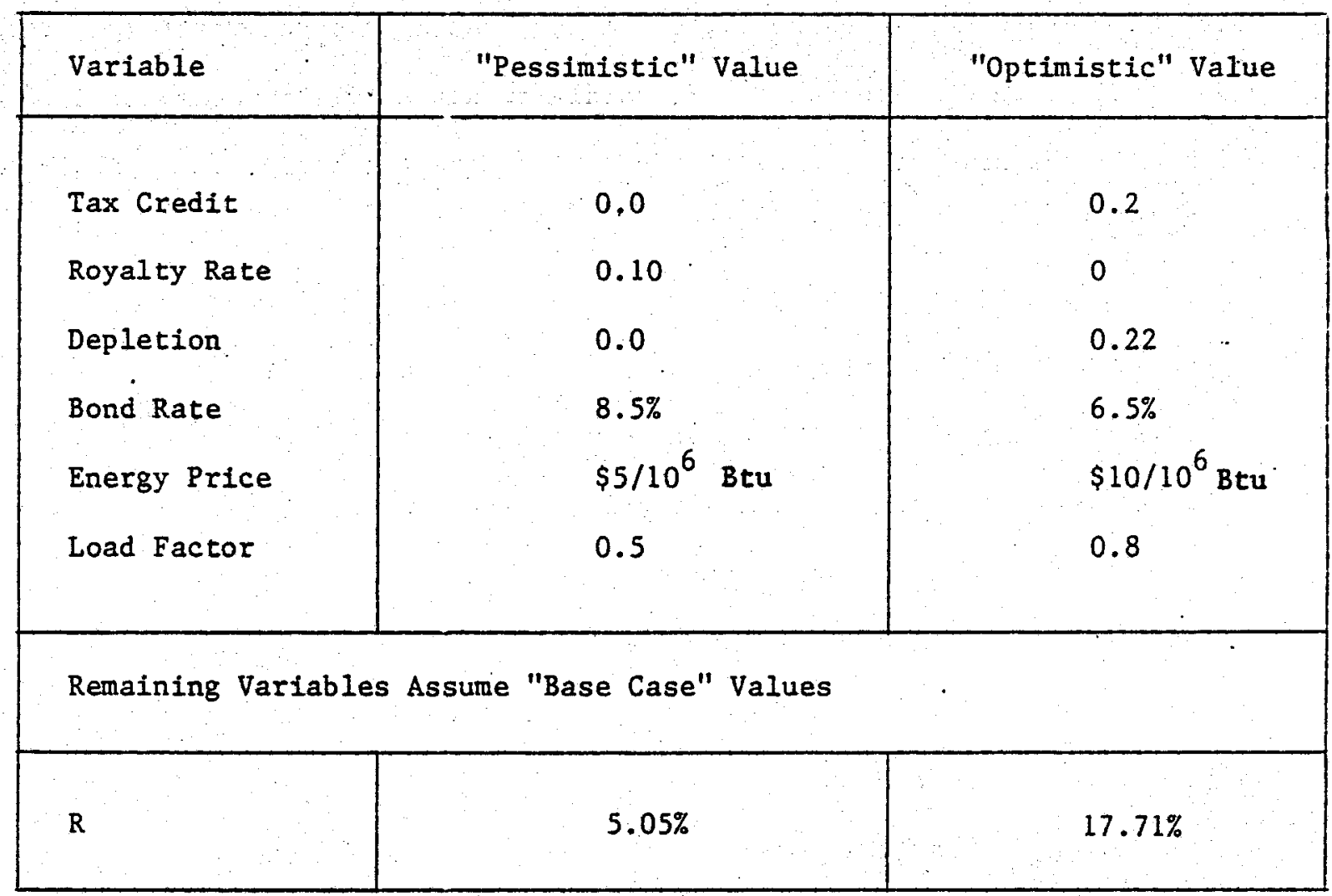

Table 12. Parameter Vaules for "Optimistic" and "Pessimistic" Market Scenarios 


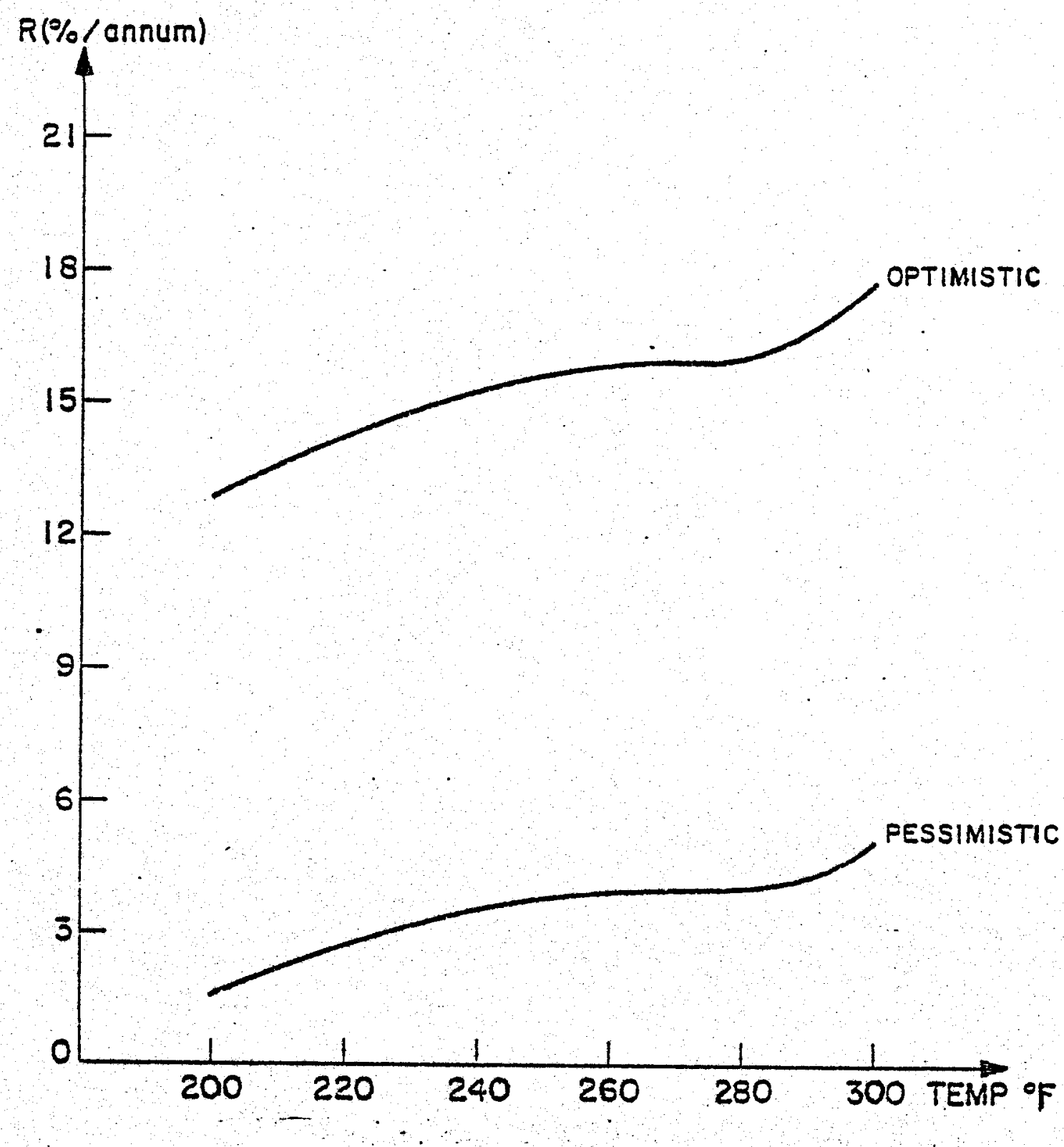

Figure 22. Internal Rates of Return for Optimistic and Pessimistic Scenarlos 


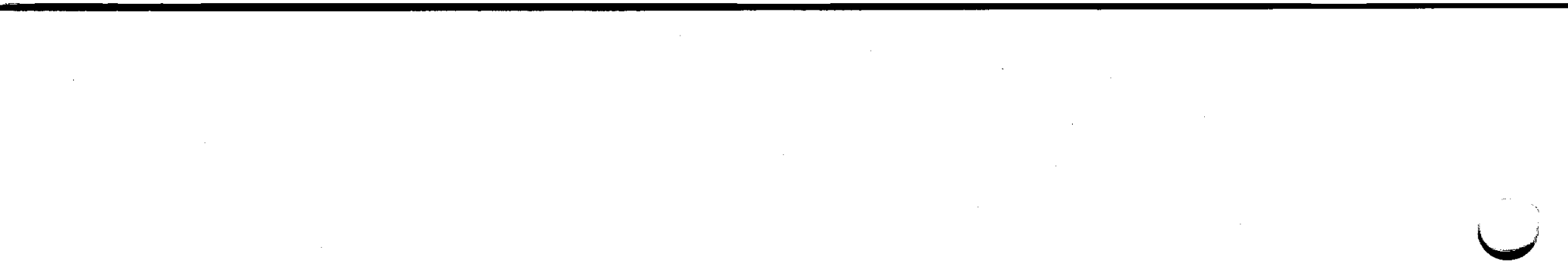

$\smile$

$\mathcal{C}$ 
B. PROGRESS IN IDENTIFYING INSTITUTIONAL FACTORS

This section will (a) present the Core Team's definition of the nontechnical Institional factors involved in the development of geothermal resources, (b) describe three procedures which have been used to obtain information relevant to Institurional barriers in the southwest region, and (c) present a summary of the results obtalned through March 1978.

\section{Definition}

The Core Team has adopted a position which parallels the one so adequately described by Schuller and others in thelr analysis of institutional problems in developing geothermul resources in the state of California. Those researchers argue that the so-called institutional problems usually occur when one participant in the development process has to deal with another. That is, the factors of interest occur as a result of actions of and the interaction among participants in the development process; actions and interactions initlated and constrained by various statutes, regulations, and policies. In short, Institutional problems are behavioral issues. To underscore the behavioral aspects of the entire process, it should be noted that any given regulation or the consequences of any given action may be perceived quite differently by different participants. For example, one developer has complained to the Core Team that it may take as long as six months to obtain a permit to drill a geothermal well. On the other hand, a state-level regutator was attempting to be quite positive when he pointed out that a permit to drill a geothermal well can be obtained in as 11 tile as 12 to 18 months. These types of behavioral problems may be resolved through a type of mutual 
learning process (institutional learning), or as a result of changes in technology or the legal and regulatory context.

Figure 23 summarizes the nature of the interactive behavioral system the Core Team has in mind. The rows and columns of the block diagram shown In Figure 23 represent "the various participants; the crossing of rows and columns shows their interaction. The third dimension shown in Figure 23 represents stages in the general development sequence.

We have begun to make inroads into acquiring the data needed to fill the cells shown in Figure 23. It should be recognized that there was no one person or agency familiar with the specifics of institutional factors in any state, nor, obviously, with the characteristics and magnitude of variations in factors across the five states in the southwest region.

\section{Procedures and Results}

Three procedures have been used to acquire information needed for an understanding of institutional factors: (a) an examination of statutes, regulations, and policies, (b) an examination of leasing and permitting information, and (c) an examination of the perceptions of geothermal developers. These three procedures and the results obtained with each will be presented below.

Regulations and policies - The Core Team drew up a list of general information needs (First Quarterly Report, Pgs. $18 \& 19$ ). These information needs were submitted to each state team. We were looking for copies of relevant regulations, other written policies, and any other documentation that might be relevant in describing the activities of participants. 


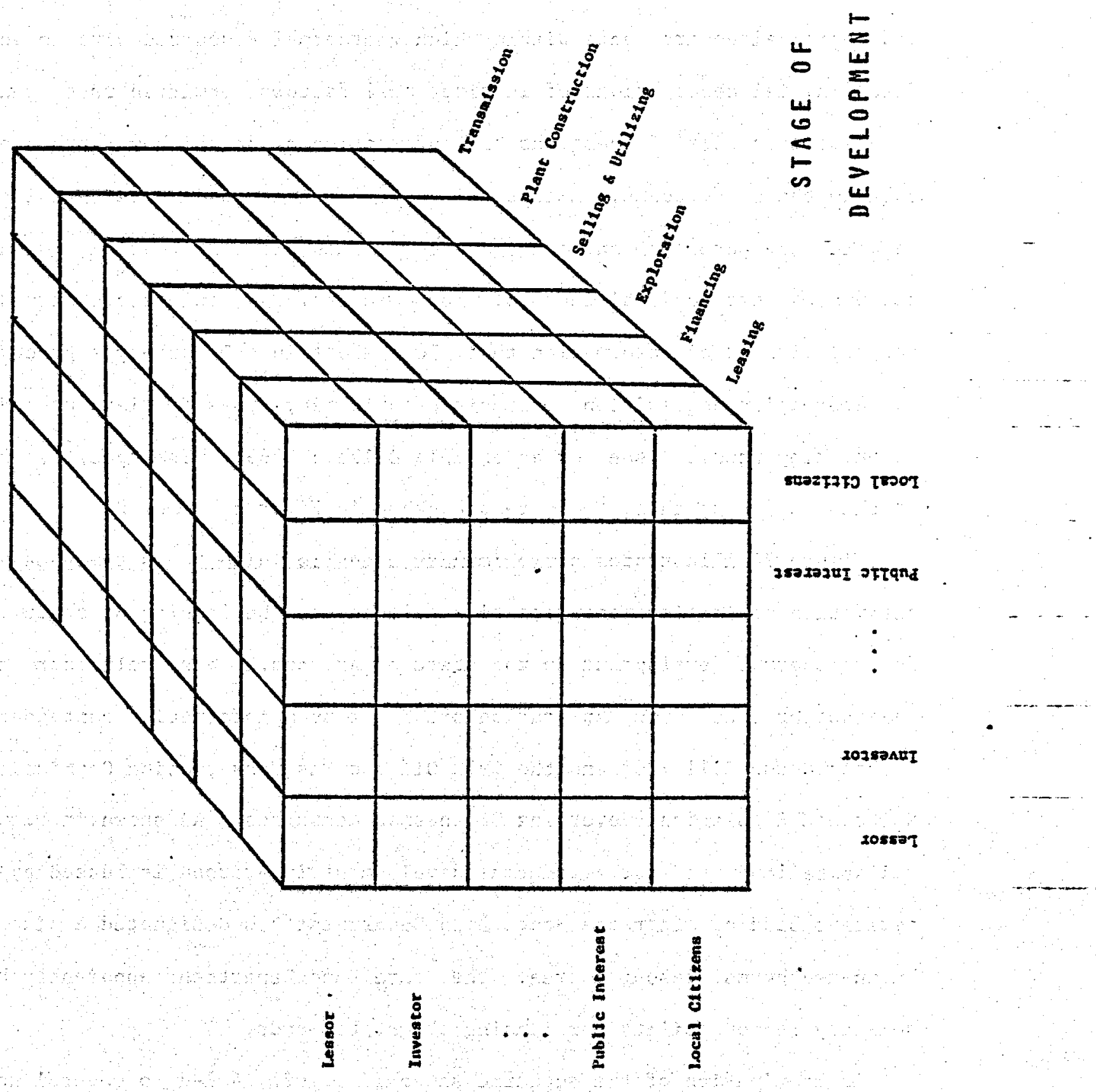

Figure 23. Nature of the Interactive Behavioral System 
As the respective state teams began to provide the information required, we were able to create a broad brush picture of the legal, institutional, and political environments within which geothermal resources were to develop. These initial descriptions of institutional factors permitted us to generate more specific sets of questions and information needs which were then sent back to the state teams. A continuing interactive process was established In which the Core Team and the state teams exchanged information and questions concerning institutional factors. The Core Team has, in effect, served as the coordinator of information that flows about in a Delphi-type procedure of information acquisition currently used in many types of planning and forecasting studies (see for an example Dalkey, 1969). Two specific examples of the results of this procedure are shown in Figures 24 and 25 .

. Figure 24 illustrates a preliminary scenario which shows time-phased activities of institutional entities relevant to the leasing of state lands for geothermal development in the state of Arizona. This preliminary scenario and another concerning exploration are based upon information contained in Arizona House B111 2257 and the 1972 Oil and Gas Conservation Commission Rules and Regulations Governing Geothermal Resources. As shown in Figure 24, all state land used for geothermal development in Arizona is leased by competitive bidding after the State Land Department has designated a site as a known geothermal resource area. The State Land Department apparently has solitary responsibility for leasing the state lands.

An examination of the scenario shown in Figure 24 led to several specific questions which were communicated to the Arizona state Team. Three examples will illustrate this phase of the interactive process: (a) There was a need to clarify just how the calls for bids were announced. (b) once leasing bids 
Time-Phased Activities

\section{Relevant to Geothermal Development}

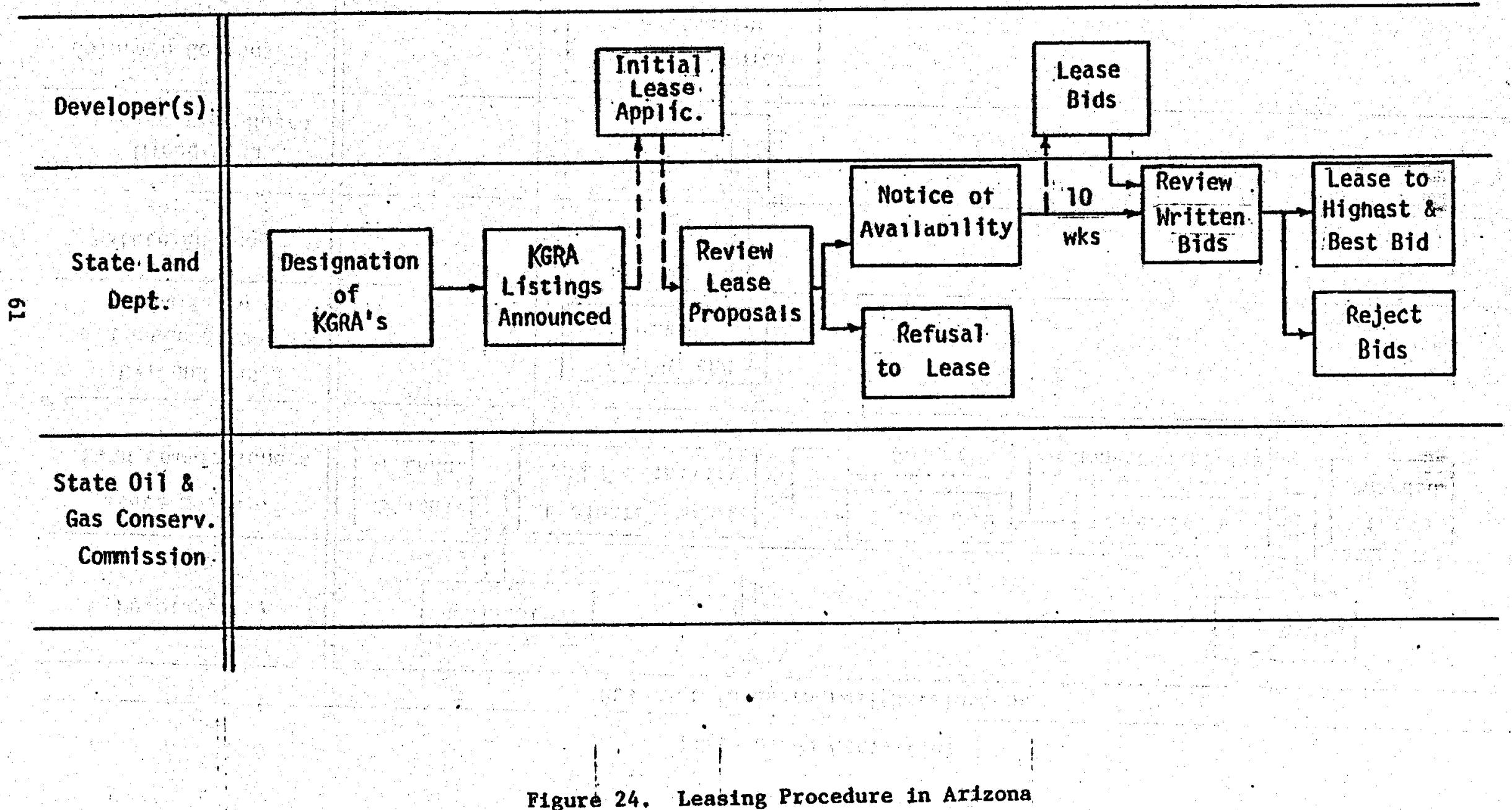

Figure 24. Leasing Procedure in Arizona 
Time-Phased Activities

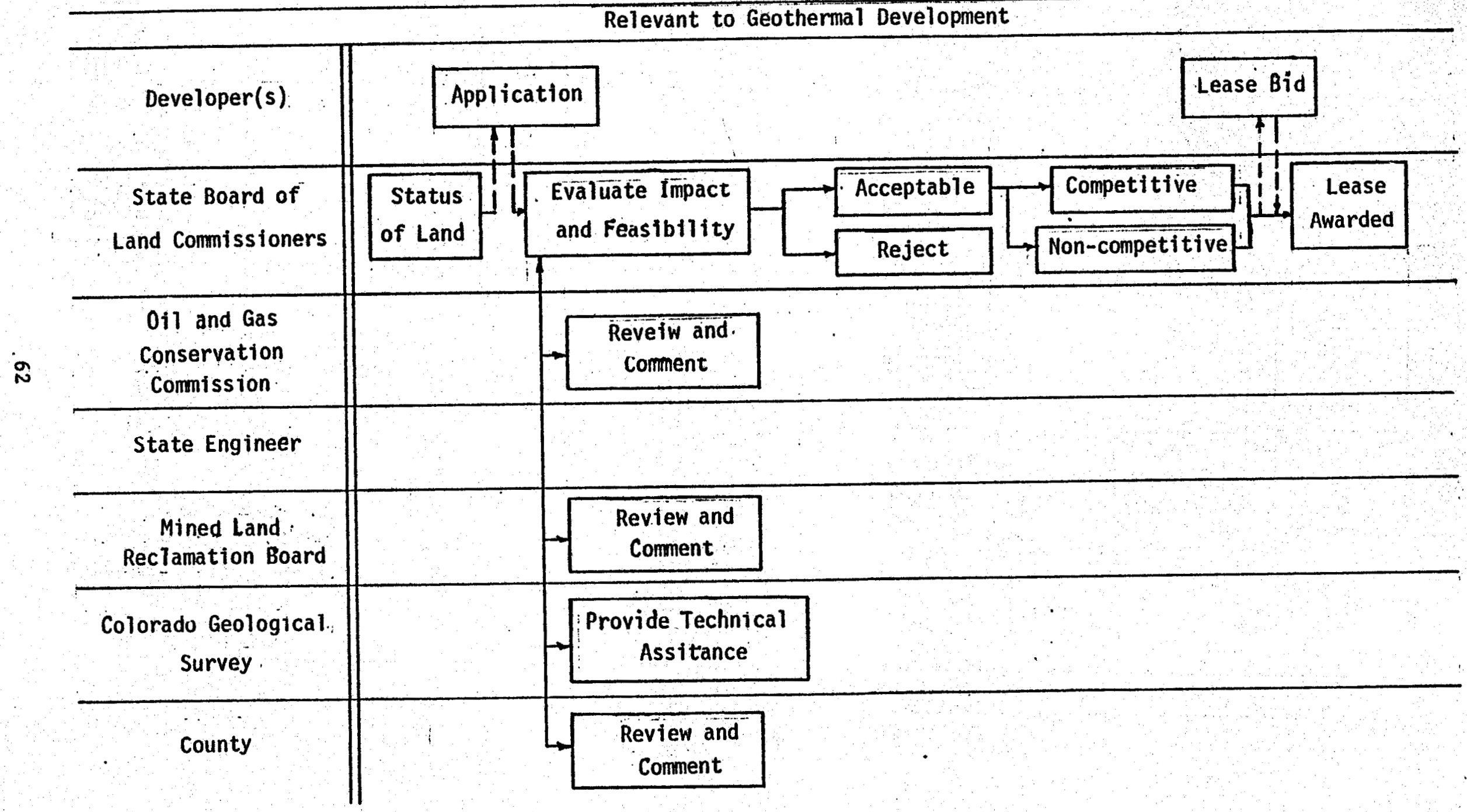

Figure 25. Leasing Procedure in Colorado 
were accepted, it was not clear how tied bids would be dealt with. We already knew that some states had anticlpated this possibility. Utah, for example, has a public drawing to resolve ties. (c) It was not clear what if any procedures there wight be within the Arizona Land Department to deal with appeals by either the applicant or the public to decistons made by the department.

In addition to specific questions and information needs, the Core Team was also able to Identify other agencles within the Arizona state government about which Information was needed. For example, the State Team was asked to provide the Core Team with information concerning the Arlzona Water Commission and the Advisory Commission on the Arizona Environment.

The scenario 11 lustrated in Figure 25 shows the time-phased activities of Institutional factors relevant to the leasing of Colorado state lands. . Several things should be noted with respect to the information contained in Figure 25: (a) The Colorado State Team estimates that the entire process of leasing state lands could be complete in seven to eight months. This type of response-time information is critical for accomplishing the objectives of the overall operations research profect. (b) Unlike the situation previously discussed for Arizona, leasing state lands in Colorado may occur through either competitive or non-competitive bidding pracesses. (c) colorado rules and regulations specifically require the Land combissioners to send coples of the developer's application to other agencies for their review and comment. Scenarios 1ike those shown in Figure 24 and 25 were constructed for each state in the southwest region for leasing, exploration, and field development stages of geothermal development. Table 13 sumarizes the information contained in these scenarios. Several facts become evident only after comparison of the rules and regulations existing in the five states. None of the states 


\begin{tabular}{|c|c|c|c|c|c|}
\hline 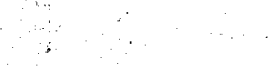 & AZ & $\mathrm{CO}$ & NV & MM & UT \\
\hline Leasing & Land Dept. & $\begin{array}{l}\text { Land Comm. } \\
\text { OGC } \\
\text { Reclam. Bd. } \\
\text { CGS } \\
\text { County }\end{array}$ & DIv. St. Lands & $\begin{array}{l}\text { Comm. of } \\
\text { Public Lands }\end{array}$ & $\begin{array}{l}\text { Div, of } \\
\text { State Lands }\end{array}$ \\
\hline $\begin{array}{l}\text { Drilling/ } \\
\text { Operations }\end{array}$ & $\begin{array}{l}011 \& \text { Gas } \\
\text { Conser. Comm. }\end{array}$ & $\begin{array}{l}011 \text { \& Gas Comm. } \\
\text { Others }\end{array}$ & St. Engr. & $011 \&$ Gas Comm & $\begin{array}{l}\text { Div. of } \\
\text { Water Rights }\end{array}$ \\
\hline Water Issues & $"$ & $\begin{array}{l}\text { St. Engr. } \\
\text { Gd. Water Cont. } \\
\text { Comm. } \\
\text { Water Qual. } \\
\text { Cont. Comm. }\end{array}$ & $\begin{array}{l}\text { St. Engr. } \\
\text { Div. Envir. } \\
\text { Protec. }\end{array}$ & St. Engr. & " \\
\hline Alr Issues & " & $\begin{array}{l}\text { Air Pollu. } \\
\text { Cont. Comm. }\end{array}$ & $\begin{array}{c}\text { Div, Envir. } \\
\text { Protec. }\end{array}$ & ? & \\
\hline
\end{tabular}

Table 13. State-Level Participants in Geotherma1 Development 


\section{t}

have any formal regulations for prelease exploratory (casual use) activity. Except for Colorado, a single office has sole responsibility for leasing state land. In addition, with the possible exception of Colorado, there are no legal and binding provisions at the state level for an environmental assessment before state land is leased for geothermal development. Drilling permits are handled by 011 and gas commissions in three states, and in Arizona the comisston has sole responstbility for all water and environmental issues which might arise with respect to field development. The extent to which the states have explicitly dealt with issues of water and environmental protection varles considerably across the region. Colorado and Nevada have assigned responsibility for these environmental factors to several agencies while Arfzona and Utah have placed all responstbility in one office.

In sumary, there is considerable variability in the status of legal and institutional barriers across the five states which comprise the southwest region. While all the information needed to conclude this approach to the overall effort is not currently available to the Core Team (or presumably to the respective state teams), it would also appear that each state has developed slightly different procedures for interacting with federal agencies. One argument often heard from developers 1s that legal and Institutional factors are a major if not the major problem Inhibiting the development of geothermal resources.

Status of geothermal development - In addition to analyzing the rules and regulations which affect the development of geothermal resources, action was initiated to determine what exactly has happened in each state with respect to leasing, exploration, and development. The Information provided by the state teams was analyzed to determine how much activity was occurring or was in the planning stage. The assumption was that an analysis of these 
activities and, by interference, the absence of significant activities, would allow the Core Team to identify barriers and opportunities.

Table 14 sumarizes the result of this approach. The upper portion of the table shows the number of acres that have been leased within each state and, when possible, the status of lease applications or land available for leasing. The numbers in parentheses refer to the number of leases or lease applications. The central row of the table shows the level of exploratory activity. The number of sites on which drilling has occurred is shown as well as the number of applications for drilling permits that have been made and/or approved. Finally, the lower portion of Table 14 shows the status of active field development within the state.

As may be seen, leasing activity varies considerably across the southwest region from nearly none in Arizona to over 600,000 acres in Nevada and Utah. The status of leasing is also moderately high in both Colorado and New Mexico. The total acres leased in Colorado include 40,000 acres which have been dropped after the completion of exploratory drilling. About 30,000 acres recently leased in New Mexico have not been identified to the Core Team as federal or state lands. Information concerning the status of lease applications or of non-leased geothermal resource land is not as complete as would be desired. Five federal KGRA's were offered in Colorado but no bids were received. Very many lease applications $(1,374)$ by 150 applicants are pending In Nevada. The latter number of pending leases seems very large. On the other hand it is worth noting that 23 or 30 KGRA's in Nevada have been offered for lease.

The level of exploratory drilling within each of the five states parallels the activity in leasing. While little exploratory drilling has occured in 


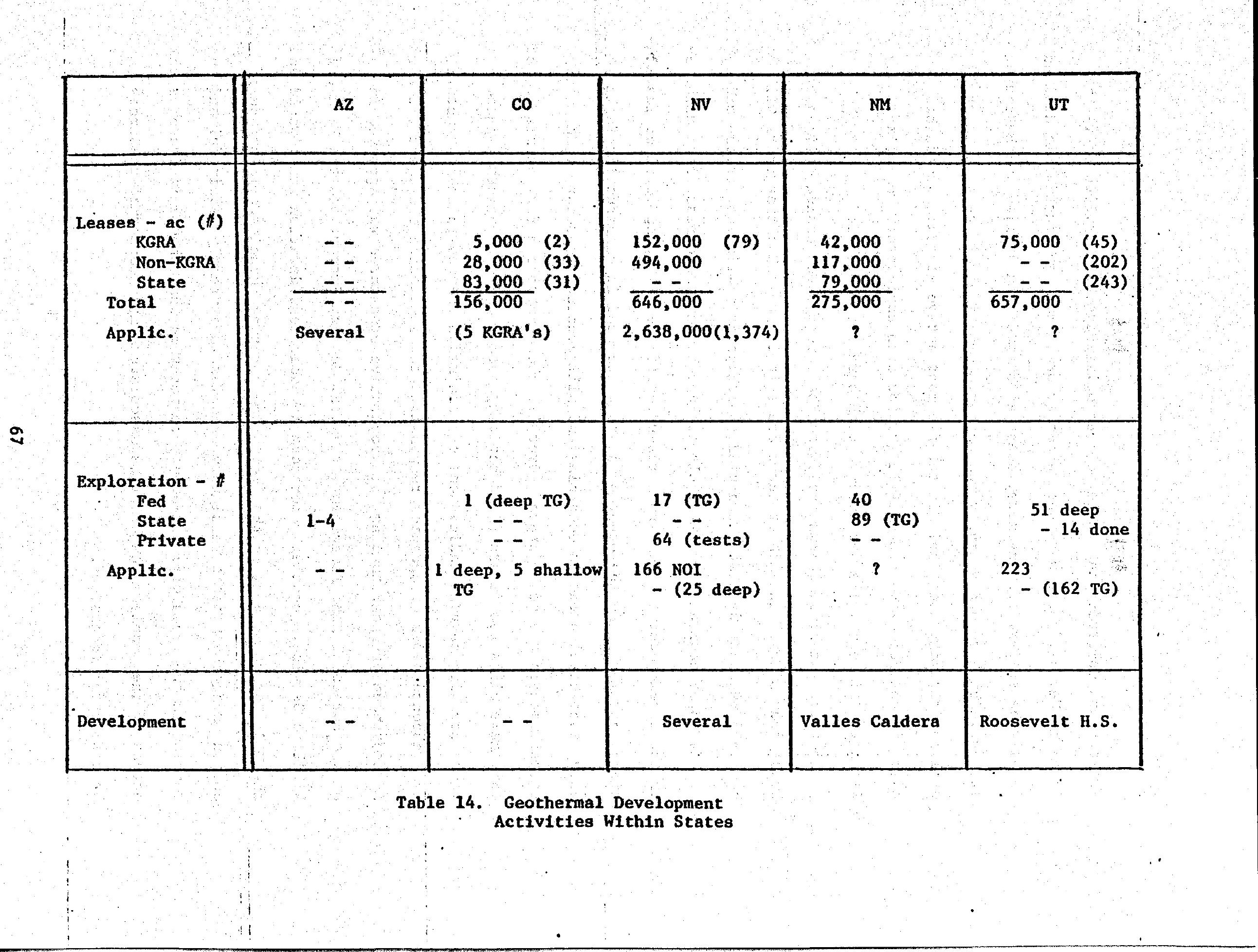


Arizona and Colorado, and while no deep wells have been drilled on federal lands in Nevada, there have been a number of thermal gradient wells drilled In all the states. Furthermore, deep wells have been drilled in the four states which have had activity in leasing. Relatively large amounts of drilling activity are likely in the two most active states: Nevada has over 150 notices of intent on file (25 for deep exploratory wells) and only 14 of the 51 deep wells approved in Utah have been drilled.

Development of geothermal resources has progressed considerably on at least four sites. In each of those areas it is projected that there will be 50-55 megawatt demonstration plants with power on-1ine before the mid-1980's.

It is, of course, very difficult to know how much progress there might be in the development of geothermal resources if there were no legal or institutfonal barriers. On the other hand, the data used in constructing Table 14 show that development is occurring and will continue to occur at an even faster rate in the near future. Overa11, there is reason for optimism. Not only have plans for future field activity been formulated by developers, there are also several indications of meaningful changes in the structure and response times of agencles responsible for regulating these activities. A memorandum of understanding for cooperative procedures was approved in 1976 by the Bureau of Land Management, the U.S. Geology Survey, and the Fish and Wildiffe Service. Another memorandum is under consideration which would add the U.S. Forest Service to the list of cooperating agencies. This type of action among the federal regulatory agencies is extremely meaningful and represents the types of inter-agency cooperation that should increase as the nature of the problems and benefits associated with geothermal resources become better understood. 
Figure 26 shows evidence of institutional learning for agencies involved In the leasing of non-KGRA lands in the state of Colorado. This figure shows the number of months required to obtain a lease for 31 different sites as a function of the date of flling the lease application. While the exact nature of the lands in question was not known to the Core Team, it is clear that leasing time has decreased from 18 to 35 months for applications filed In January, 1974 to only 10 months for applications filed in March, 1975. As suggested earlier, there is evidence that barriers to geothermal development will be further reduced in the future.

Many of the Improvements in the status of Institutional barriers have occurred in the federal arena. It is expected that similar improvements will occur if meaningful integration of objectives and procedures were to occur among state agencles and between agencies at the state and federal levels. Perceptions of developers - The Core Team working through the state teams has begun to Informally survey the developers and prospective developers of geothermal resources. These individuals and representatives of corporate Interests are frequently the most knowledgeable participants and they certainly have great personal and financial investment in the process of geothermal development. It is our Intention to examine the actions and perceptions of these developers to determine the extent to which a coherent and consistent picture emerges concerning the factors which account for their successes and fallures. This approach to understanding the Institutional barriers and opportunities has only just begun. The success of this approach will depend entirely on the developers abllity and willingness to cooperate with the state and Core Teams. 


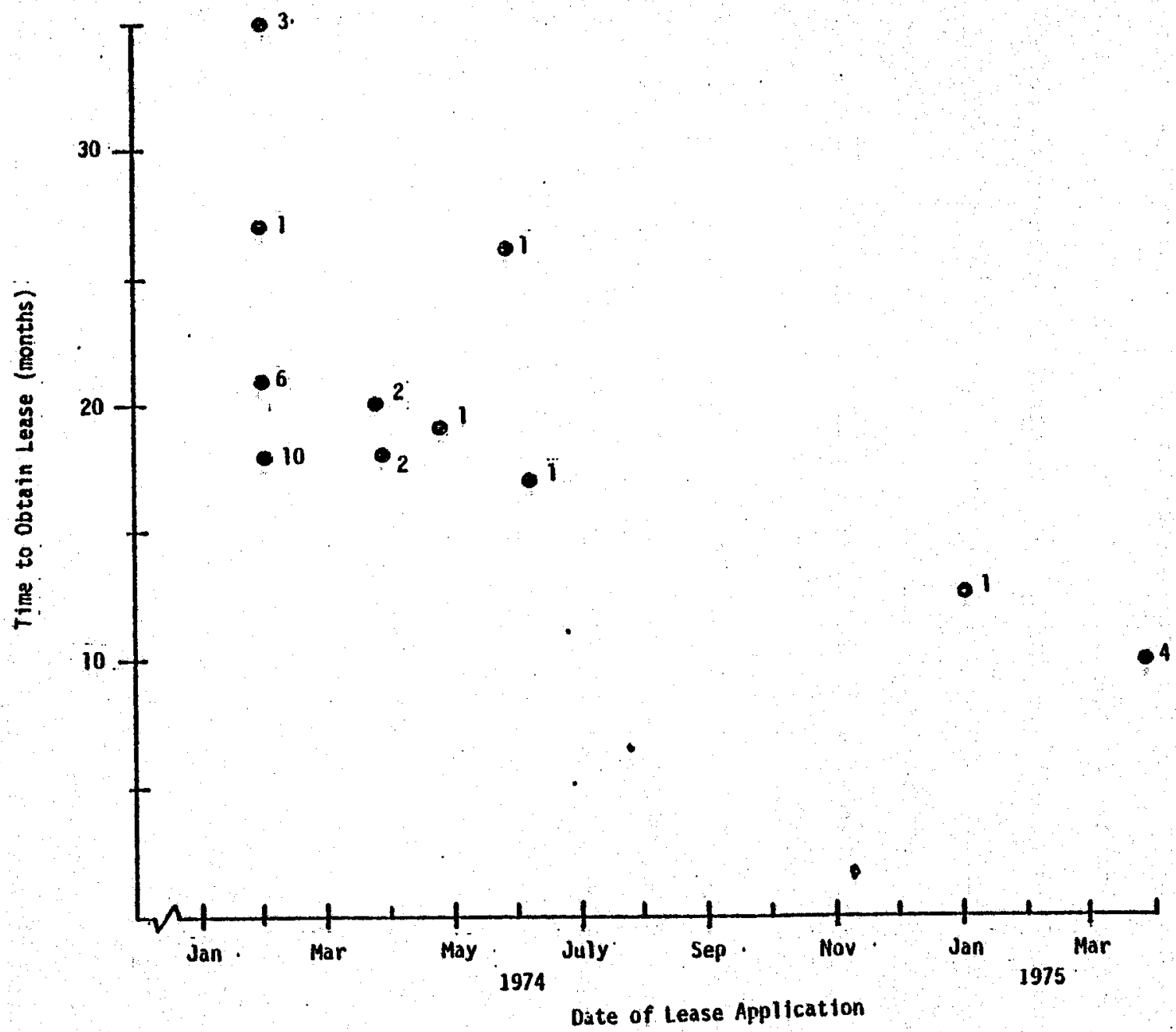

Figure 26. Leasing TIme Non-KRGA (Federa1) - Colorado 
C. THIRD QUARTERLY REGIONAL ADVISORS GROUP MEETING

The Third Quarterly Regional Advisors Group Meeting was held in Reno, Nevada on March 8.

Progress to date by the Core and state teams was presented.

Discussion items included:

- Technical details of several of the direct-use geothermal applications

- BLM leasing activity

- Collateral DGE programs

- State and Regional development scenarios

Mr. George Vranesh presented a comparison and analysis of federal and state laws and regulations.

See Appendix C for the list of attendees. 
$\mathcal{U}$

$=$

: 
D. RPPM EFFORT

On the Regional Program Progress Monitor (RPPM) work continued on establishing a data base and a data base management system. The data base Is set up on the IBM $360 / 65$ at New Mexico state University. The APL language is used for development since the Core Team has an Interactive terminal in its work area. The term "E1le" will be used interchangeably with "data base" because it is conventent to think of a data bese as a large file or a table contalning data arranged in an orderly manner. The data base is set up in a relational structure because of the flexibility which it allows.

The geothermaldata base is presently constructed in two parts in order to meet the needs of the project. One part of thedata base contains the information relating to individual geothermal sites in the region; the other part contains population data about citles and towns in the region. First a description of how the geothermal site data is arranged will be given and then a description of the population part of thedata base will follow.

For each geothermal site the data bese contains the site name, location, temperatures, reservolr volume and related information as shown in Figure 27. The Information came from state teams and related sources and at the present time the file contains data on approximately 400 geothermal sites. As new Information is recelved by the core Team, it is added to the data base. Now that the geothermal site date is in computer storage, it is avallable for use in computations. One of the first studies for which it was used was the calculation of recoverable energy. This quantity could be calculated for all sites in the file in a few hours. On the other hand, if the same information had been calculated manually, it would have taken several days. Moreover, the results were typed in the desired format by the terminal typewriter under 
REGIONAL OPERATIONS RESEARCH

for the Development of

\section{GEOTHERMAL ENERGY DATA BASE}

\section{Nevada}

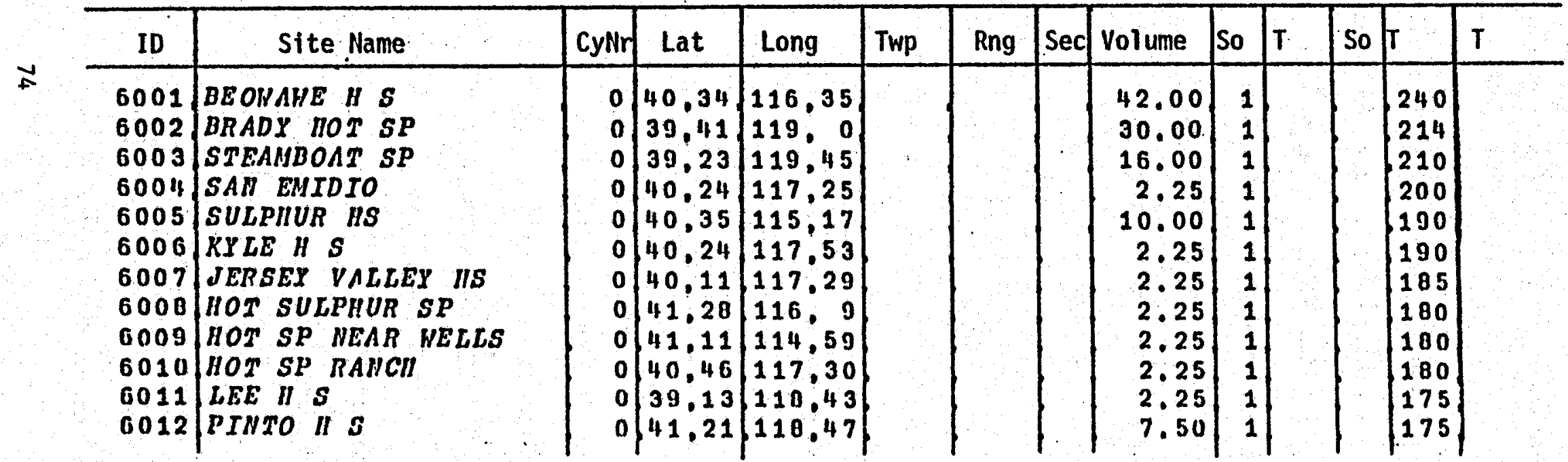

Now Maxico Enargy Instltute

FEBRUARY 1978

Figure 27 
computer control, so there was no need for the services of a typist. In addition to having the geothermal site avallable for all kinds of calculations, the Core Team can use many of the APL functions with the data. Thus the records can be rearranged in alphabetical order or put in order by increasing wellhead temperature or decreasing latitude; depending on the needs of the project. Plotting subroutines avallable in APL allows quick plots of one varlable against another.

The population part of the data base consists of a list of cities and towns, their geographic positions and populations. Included in this list are all c1tles and towns that have populations of more than 500 people in Region 4 and those in adjoining states within 100 miles of Region 4. This information is useful when it is necessary to determine the potential market area for various geothermal sites. Having these data available makes it possible to calculate how many people live within a certain distance of a specified geothermal site. The results of such a study are shown in Figure 28 , To do this kind of a study for all the sites in one state would require a tremendous amount of computation which would be feasible only if a computer were avallable.

The data basewill be expanded to meet the requirements of the project. New geothermal sites will be added and new information will be added to the sites already in the file. Leasing and drilling information, permitting procedures and requirements, technology, and cost factors will be added as format and content are developed. This information will be avallable for display in reporting and for computation and network support as procedures are developed. 


\section{Nevada}

PROJECT ID NO 6001

SITE NAME

LOCATION

AREA POPULATION

BEOWAWE HS

$4034 \mathrm{~N} 11635 \mathrm{~W}$

10790

CITY

BATTLE MOUNTAIN

CARLIN

ELKO CITY

สั
STATE

$\begin{array}{ll}W V & \text { LANDER } \\ N V & \text { ELKO } \\ N V & \text { ELKO }\end{array}$

6002

BRADY HOT SP

$3941 N$ 104635

$1190 \mathrm{~W}$

\author{
.
}

AREA POPULATION

CITY

FALLON

FALLON STATION

LOVE LOCK

RENO

SPARKS

Y ERRINGTON

STATE

$\begin{array}{ll}N V & \text { CHURCHILL } \\ N V & \text { CHURCHILL } \\ N V & \text { PERSHING } \\ N V & \text { WASHOE } \\ N V & \text { HASHOE } \\ N V & \text { LYON. }\end{array}$

POPULATION

1856

1313

7621 
E. STATE TEAM REPORTS

The state team reports are given in Appendices D, E, F, G and H. The State Teams Report increased interaction with state administration and key officials in economic and industrial communities.

A Core/State Team Workshop was held in Las Cruces with the Utah team during February 14 and 15.

The updated status of geothermal development is extracted here: 


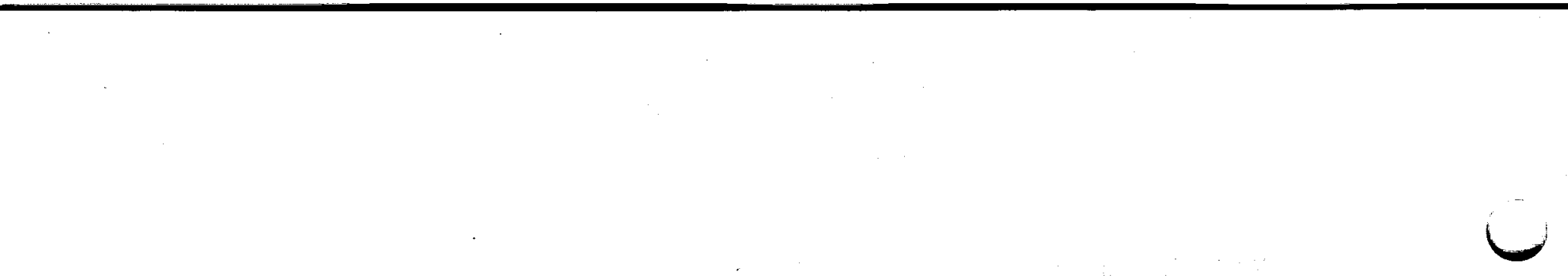




\section{COLORADO}

Resource Potential

The total Btu's contained in the hydrothermal systems in Colorado were estimated using the method and the formula employed in U.S.G.S. Circular 726. However, rather than the 14 areas indicated in that circular, this assessment covers all 56 identified geothermal resource areas. Estimates of the boundaries and thickness of the reservoirs were based upon intimate knowledge of the areas and their geology, rather than upon generalized areal estimates as in Circular 726.

The total eriergy contained in these systems is estimated to be $\mathbf{5 . 9 1 4}$ quads. Table 16 ists the areas, their areal extent and the energy estimated to be contained in each.

The available energy indicated refers to usable energy. This was calculated from the energy estimated to be contained in the ground. As indicated in Circular 726, if one-fourth of the stored energy is assumed to be recoverable at the surface and the efficiency of utilization is assumed to be 24 , some idea may be derived of the actual potential. This is an extremely rough gauge, not taking into account variations of permeability, flow rates or variation of efficiency in different uses. Lacking more accurate information, use of these factors at least reduces the estimates of energy potential to a more reasonable number. Total available energy is estimated to be .35 quads. 


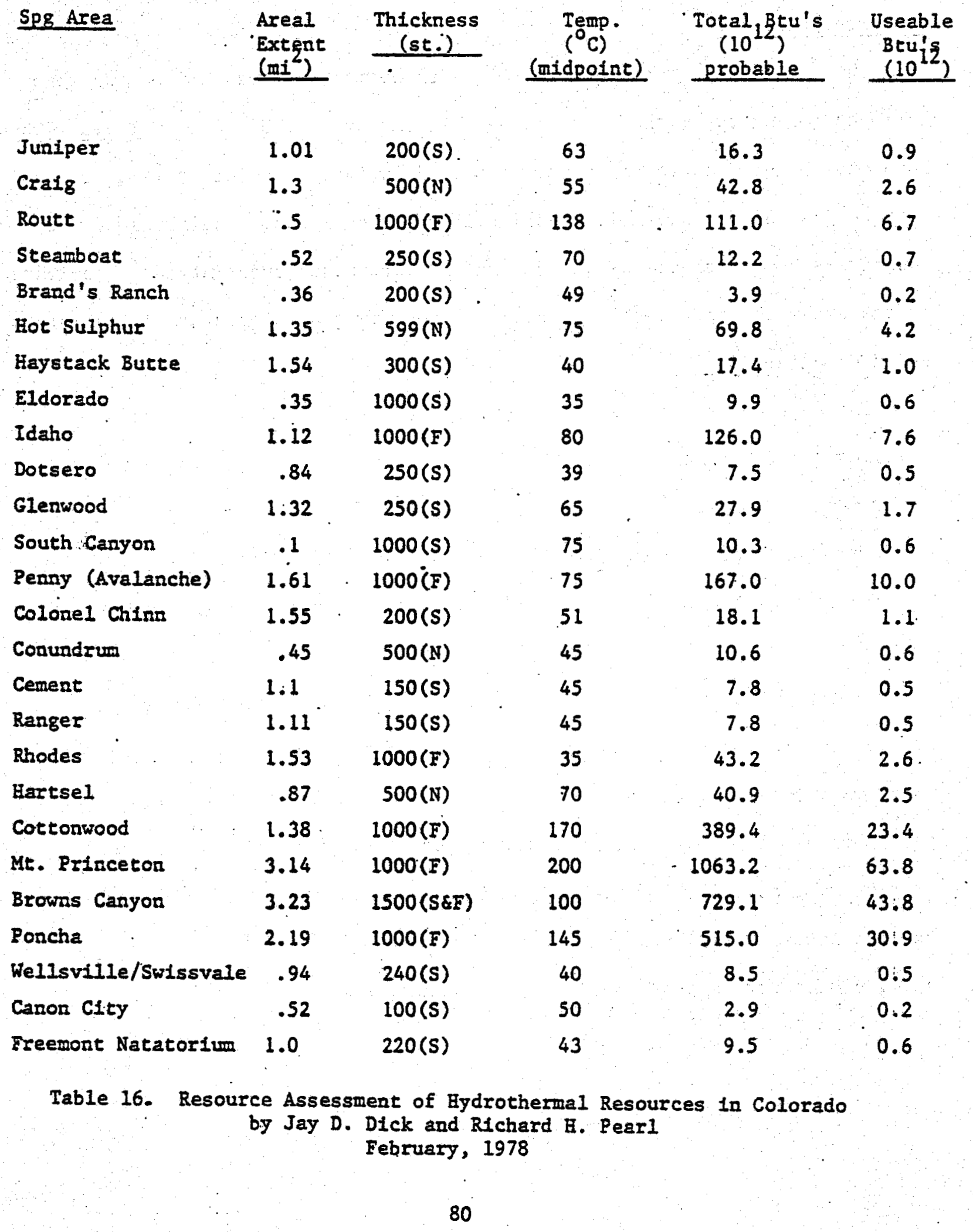




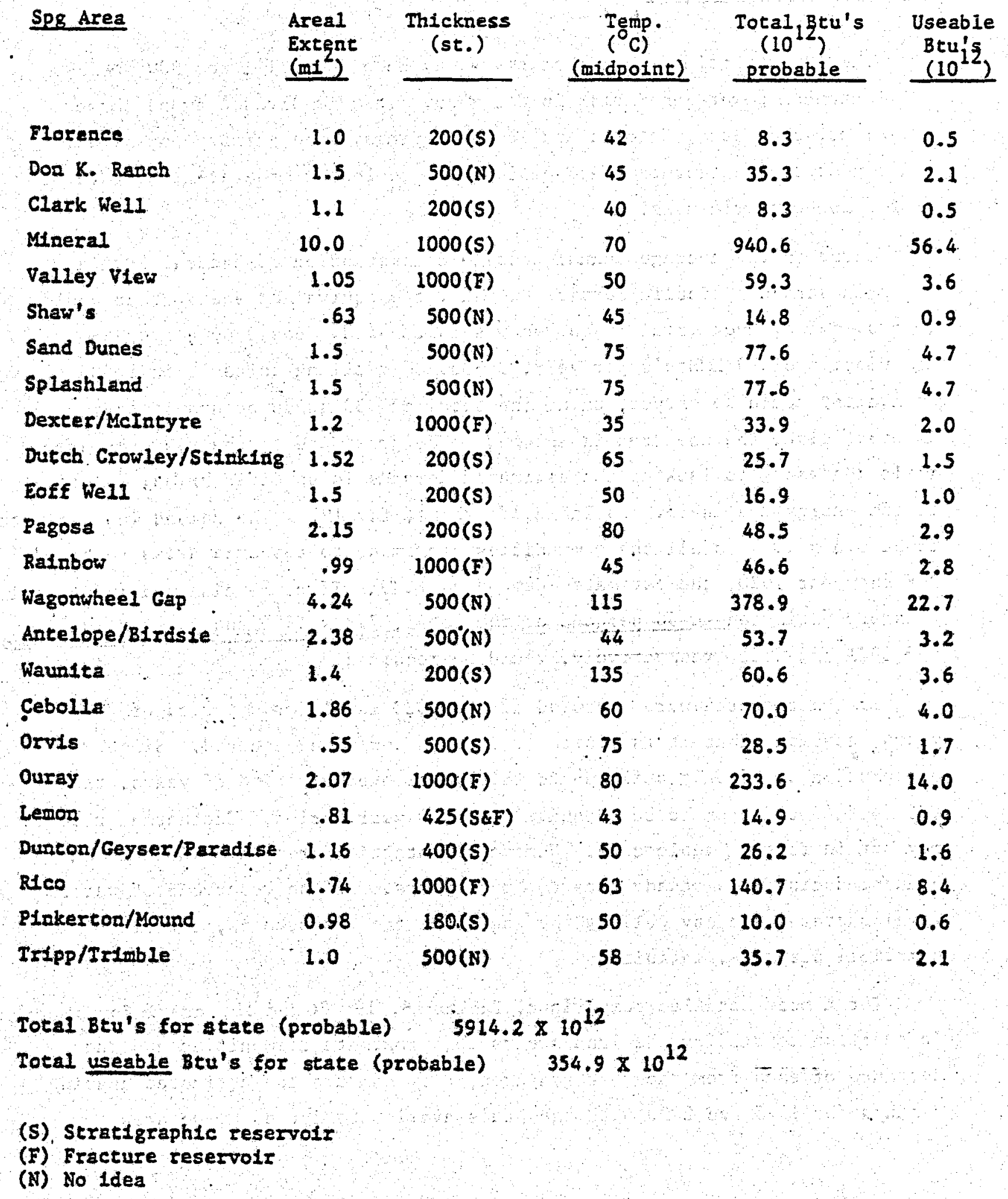


TOTAL RESOURCE POTENTIAL

The investigation shows that there may be a potential for 500 Mw of electrical power generation in Colorado. This is divided among three areas, Mt. Princeton, Cebolla and Poncha Springs. The primary potential, since most of the resources are believed to be low or moderate temperature, is for non-electric uses.

Based on the average annual household consumption of natural gas in the area served by Public Service Company, the equivalent energy that could be provided by geothermal resources was calculated. Based upon average consumption of 89 MBtu's per year, 3,935,800 dwelling units or their equivalent could be served, using the total of .35 quads of usable energy. However, since the use area is assumed to be proximate to the resource area, it is necessary to look at the estimated demands in specific areas, relative to the energy available. As Table 17 shows, for 1975, the demand was estimated to be $3.6 \times 10^{12}$ in all the communities proximate to resource areas combined. For the year 2020, the estimated demand is 8.17 . If comercial and fndustrial uses are estimated at 50 percent of the total, $7.2 \times 10^{12}$ and $16.34 \times 10^{12}$ for 1975 and 2020, respectively, would be required.

If the resource were consumed at the 2020 level for a period of 30 years, assuming that it is finite, .49 quads would be required. Since consumption would only build up to this level over a period of years, the .35 quads would seem to be adequate for a 30 year period. Geothermal resources may not in fact be depletable. Numerous geothermal areas are known to have been producing at a steady rate for many years. If the reservoir of water remains steady, it may well be the case that the resource is, for all practical purposes, Infinite.

For a more detailed comparison, Tables 18, 19,20 and 21 are informative. In addition to showing the land ownership, proximate commuities and the distance of each from the resource area, they compare the estimated heating demands for 1975 and 2020 with the Btu's available, for each use area. 


\begin{tabular}{|c|c|c|c|c|c|}
\hline $\begin{array}{c}\text { NUMBER } \\
\text { OF } \\
\text { COMMUNITIES } \\
\end{array}$ & $\begin{array}{c}1975 \\
\text { ESTIMATED } \\
\text { POPULATION }^{2} \\
\end{array}$ & $\begin{array}{c}1975 \\
\text { ESTIMATED } \\
\text { HOUSEHOLD } \\
\text { ENERGY } \\
\text { PEMAND } \\
\left(10^{\text {PEU'B })}\right. \\
\end{array}$ & $\begin{array}{c}2020 \\
\text { PROJECTED } \\
\text { POPULATION } \\
\end{array}$ & $\begin{array}{c}2020 \\
\text { ESTIMATED } \\
\text { HOUSEHOLD } \\
\text { ENERGY } \\
\text { DEMAND } \\
\left(10^{12 \text { Btu's })}\right. \\
\end{array}$ & $\begin{array}{c}\text { AVAILABLE } \\
\text { USABLE } \\
\text { GEOTHERMIAL } \\
\text { FEERGY } \\
\left(10^{\text {PELU's })}\right. \\
\end{array}$ \\
\hline 66 & 120,815 & 3.6 & 275,367 & 8.17 & 354.9 \\
\hline
\end{tabular}

Table 17. Total Potential For Geothermal Residential Use in Colorado: 1975-2020

1 Based on average household consumption of natural gas by customers of Public Service Company of Colorado.

2 .

Does not Include Boulder or Pueblo.

Source: Colorado Geological Survey, based on data from Colorado Geological Survey, Colorado Diviston of Planning, and USGS CIrcular 726. 
TABLE 18

NON-ELECTRIC SITES FOR GEOTIERMAL DEVELOPMENT

Catecory II B

\begin{tabular}{|c|c|c|c|c|}
\hline $\begin{array}{l}\text { AREA } \\
\text { NAME }\end{array}$ & $\begin{array}{l}\text { AREA } \\
\text { NUNBER }\end{array}$ & $\begin{array}{l}\text { LAND } \\
\text { ONAERSHIP }\end{array}$ & $\begin{array}{l}\text { PROXIMATE } \\
\text { COHAIUNITIES }\end{array}$ & DISTANCE \\
\hline $\begin{array}{l}\text { Glenwood } \\
\text { Hartgel }\end{array}$ & $\begin{array}{l}11 \\
19\end{array}$ & $\begin{array}{l}\text { Fee/BLM/NF } \\
\text { Pee/State/BLM }\end{array}$ & $\begin{array}{l}\text { Glenwood Spgs. } \\
\text { Leadvilie } \\
\text { Fairplay }\end{array}$ & $\begin{array}{r}0 \\
30 \\
16\end{array}$ \\
\hline $\begin{array}{c}\text { Mineral/Valley } \\
\text { Vlew }\end{array}$ & 31,32 & Fee/State/B1w & $\begin{array}{l}\text { Saguache } \\
\text { Crestone }\end{array}$ & $\begin{array}{l}12 \\
18\end{array}$ \\
\hline Shaws: & 33 & $\begin{array}{l}\text { Fee/BLM/NE/ } \\
\text { State }\end{array}$ & $\begin{array}{l}\text { Mof fat } \\
\text { Del Norte } \\
\text { Center }\end{array}$ & $\begin{array}{r}5 \\
12\end{array}$ \\
\hline $\begin{array}{l}\text { Sand Dunes } \\
\text { Splashliand }\end{array}$ & $\begin{array}{l}34 \\
35\end{array}$ & $\begin{array}{l}\text { State/Fee } \\
\text { Fee/State }\end{array}$ & $\begin{array}{l}\text { llooper } \\
\text { Monte Vista } \\
\text { Alamosa } \\
\text { Blanca }\end{array}$ & $\begin{array}{r}2 \\
16 \\
2 \\
20\end{array}$ \\
\hline $\begin{array}{l}\text { Pagosa Spgs. } \\
\text { Waunlta }\end{array}$ & $\begin{array}{l}41 \\
46\end{array}$ & $\begin{array}{l}\text { Fee/State } \\
\text { Fee/NF/BLH/ } \\
\text { State }\end{array}$ & $\begin{array}{l}\text { Pagosa Spgs. } \\
\text { Gunnlson }\end{array}$ & $\begin{array}{r}0 \\
22\end{array}$ \\
\hline $\begin{array}{l}\text { He. PrInceton } \\
\text { Poncha Spgs. }\end{array}$ & $\begin{array}{l}21 \\
23\end{array}$ & $\begin{array}{l}\text { Fee/BLy/NF } \\
\text { Fee/State/ } \\
\text { BLY/NF }\end{array}$ & $\begin{array}{l}\text { Buena V1sta } \\
\text { Poncha Spgs. }\end{array}$ & $\begin{array}{r}10 \\
0\end{array}$ \\
\hline
\end{tabular}

ESTIMATED
1975
RESIDENTIAL
HEATINC
PEMAND
(10 USABLE
BTU'S)

\begin{tabular}{|c|c|c|}
\hline $\begin{array}{l}\text { OSADL'S } \\
\text { BTU'S } \\
\text { AVAI'HALE } \\
\left(10^{2}\right)\end{array}$ & $\begin{array}{c}\text { GALLONS } \\
\text { OF FHyID. } \\
\left(10^{1}\right)\end{array}$ & $\begin{array}{c}1975 \\
\text { AREA } \\
\text { POPULATION }\end{array}$ \\
\hline $\begin{array}{l}1.7 \\
2.5\end{array}$ & $\begin{array}{l}1.4 \\
1.8\end{array}$ & $\begin{array}{l}5,351 \\
4,872\end{array}$ \\
\hline 60.0 & 46.1 & 799 \\
\hline .9 & 1.3 & 3,382 \\
\hline $\begin{array}{l}4.7 \\
4.7\end{array}$ & $\begin{array}{l}3.1 \\
3.1\end{array}$ & $\begin{array}{r}114 \\
13,111\end{array}$ \\
\hline $\begin{array}{l}2.9 \\
3.6\end{array}$ & $\begin{array}{l}1.8^{\circ} \\
1.2\end{array}$ & $\begin{array}{l}1,572 \\
5,639\end{array}$ \\
\hline $\begin{array}{l}\text { Haste heat } \\
\text { Waste heat }\end{array}$ & & $\begin{array}{r}2,549 \\
339\end{array}$ \\
\hline & & 37,728 \\
\hline
\end{tabular}

Fee/state

Poncha Spgs.

37,728
2020

AREA

PROJECTION

.16

11,389
5,496

1,406

6,071

373
32.537

4.

4,442
12,979

.39
81,437

2.23
ESTLLATEO

2020

ESTDENTIAL

HEATING

$\left(10^{\text {PETLAND }}\right.$ USABLE

BTU's)

.34
17

.04

.18

.97

2.0
.11

$\begin{array}{r}.08 \\ .01 \\ \hline 1.123\end{array}$ 
TABLE 19

WON-ELECTRIC SITES FOR GEOTHERMAL DEUELOPNENT

CATEGORY III A

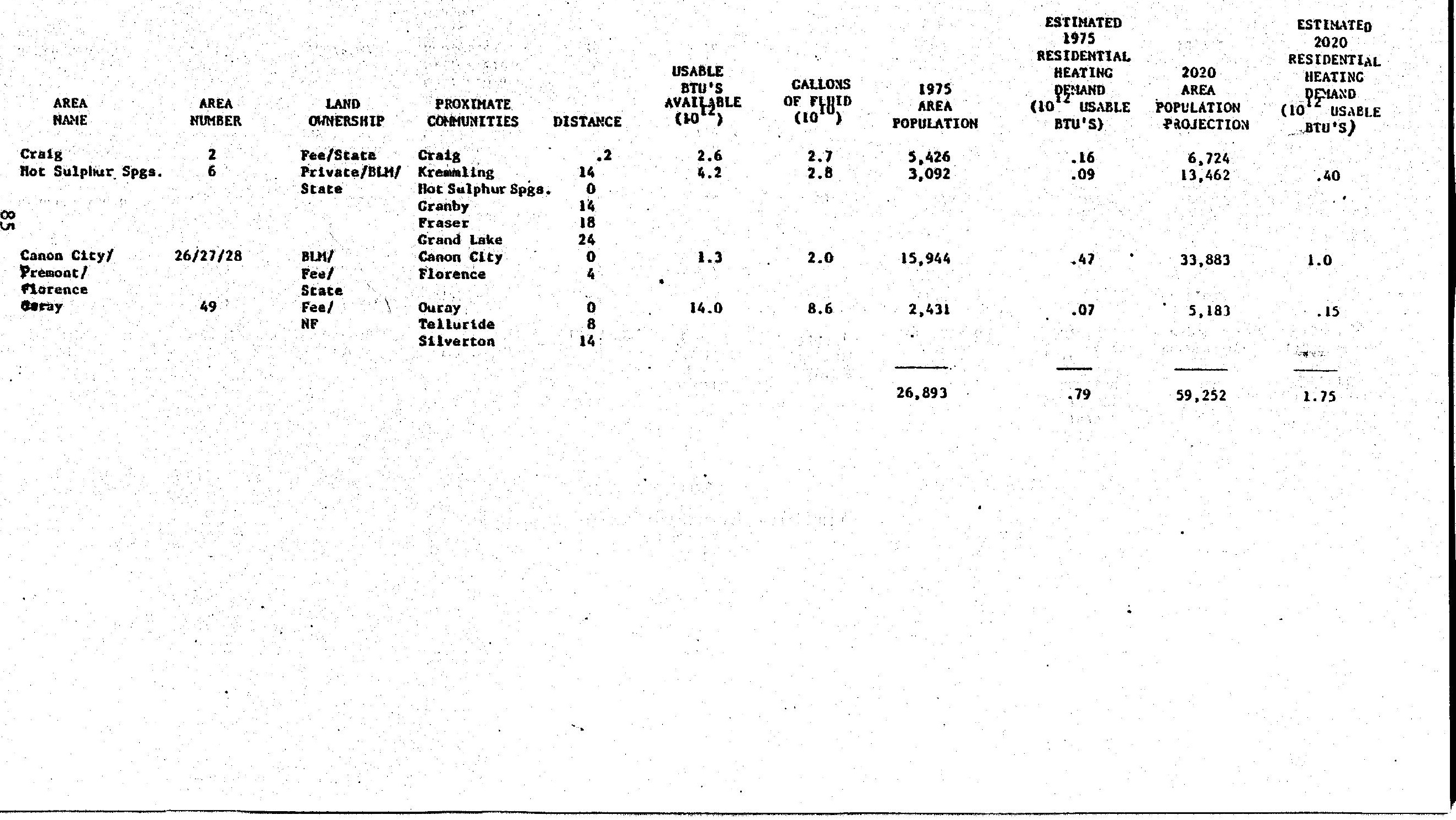


TABLE 20

NON-ELECTRIC SITES FOR GEOTHERMAL :EVVLLOPMENT

CATECORY III B

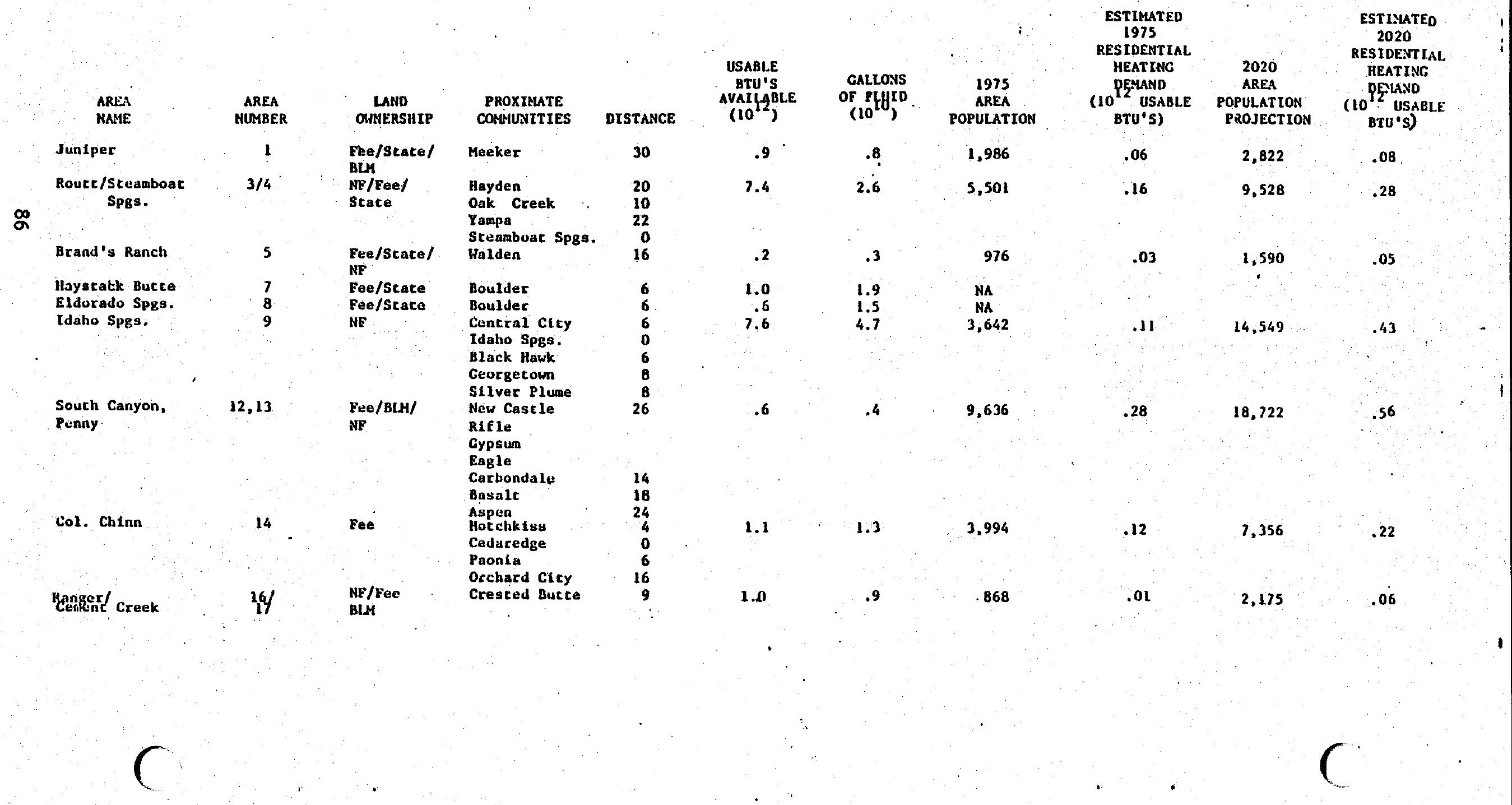


NON-ELECTAIC SITES EOR GEOTHERYAL DEVELOPMENT

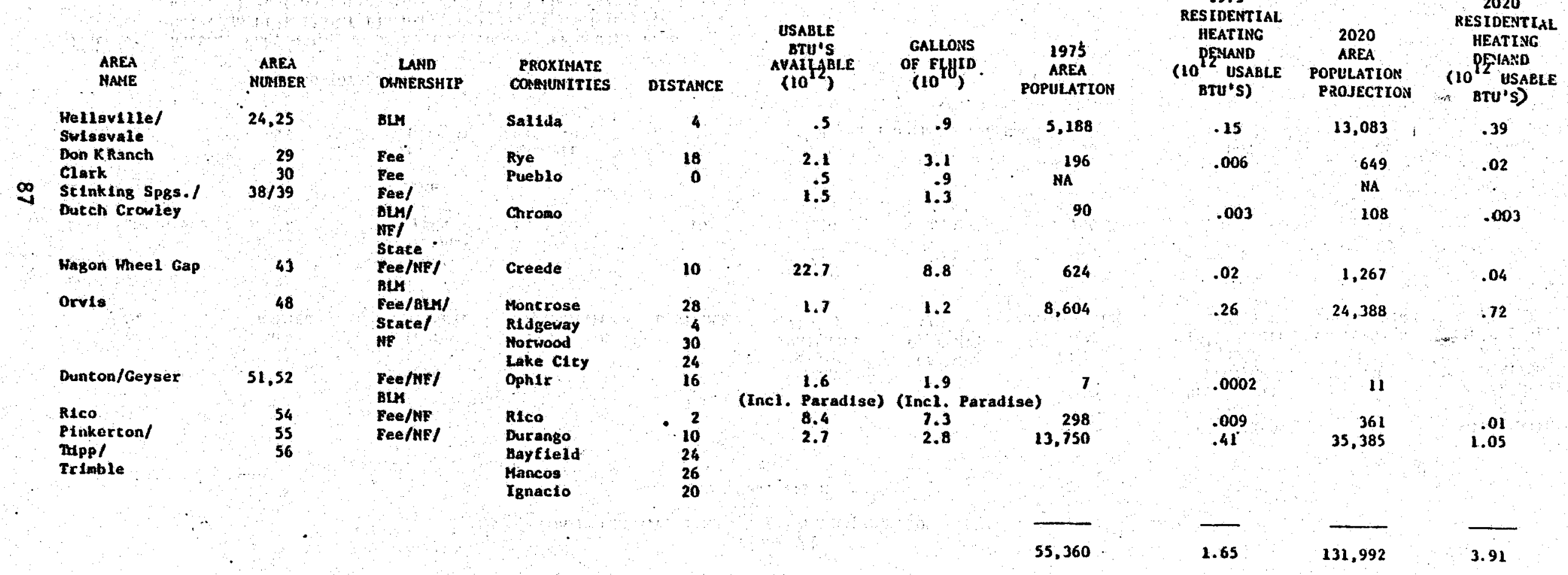


TABLE 21

NON-ELECTRIC SITES FOR GEOTHERMAL DEVELOPMENT

CATEGORY III C

\begin{tabular}{|c|c|c|c|c|}
\hline $\begin{array}{l}\text { AREA } \\
\text { NAASE }\end{array}$ & $\begin{array}{c}\text { AREA } \\
\text { NUNAER }\end{array}$ & $\begin{array}{l}\text { LAND } \\
\text { OINERSUIP }\end{array}$ & $\begin{array}{l}\text { PROXIMATE } \\
\text { CONMUNITIES }\end{array}$ & DISTANC \\
\hline $\begin{array}{l}\text { Dotgero } \\
\text { Rhodea }\end{array}$ & $\begin{array}{l}20 \\
18\end{array}$ & Bee/NP/ & - & \\
\hline $\begin{array}{l}\text { Dexter/McIntyre } \\
\text { Ra Ĺnbow } \\
\text { Antelope/ }\end{array}$ & $\begin{array}{r}36,37 \\
\quad 42 \\
-\quad 45\end{array}$ & $\begin{array}{l}\text { Fee/BLM } \\
\text { WF } \\
\text { NF/Fee }\end{array}$ & $\begin{array}{r}\text { La Jara } \\
-\end{array}$ & 10 \\
\hline $\begin{array}{l}\text { Lemon } \\
\text { Paradise } \\
\text { Conundrum }\end{array}$ & $\begin{array}{l}50 \\
53 \\
15\end{array}$ & $\operatorname{sim}_{\text {BIM }}$ & $\begin{array}{r}\text { Saw P1t } \\
-\end{array}$ & 4 \\
\hline
\end{tabular}

\begin{tabular}{|c|c|c|}
\hline $\begin{array}{l}\text { BTU'S } \\
\text { AVAIL'HLE } \\
\left(10^{B}\right)^{-1}\end{array}$ & $\begin{array}{c}\text { GALLONS } \\
\text { OF FHUID } \\
\left(10^{1}\right)\end{array}$ & $\begin{array}{c}1975 \\
\text { AREA } \\
\text { POPULATION }\end{array}$ \\
\hline $\begin{array}{r}.5 \\
2.6\end{array}$ & 6.9 & \\
\hline $\begin{array}{l}2.0 \\
2.8 \\
3.2\end{array}$ & $\begin{array}{l}5.0 \\
4.1 \\
5.0\end{array}$ & 796 \\
\hline Include & $\begin{array}{c}1.4 \\
\text { Ith Dunton }\end{array}$ & yser \\
\hline .6 & .9 & $\frac{-734}{120,815}$ \\
\hline
\end{tabular}

$\begin{array}{cc}\text { ESTIMATED } & \\ \text { 1975 } & \\ \text { RESIDENTIAL } & \\ \text { HEATING } & \text { 2020 } \\ \text { PEAANO } & \text { AREA } \\ \text { (10 PENASALE } & \text { POPULATION } \\ \text { BTU'S) } & \text { PROJECTION }\end{array}$

EST LMATED 2020

RESIDENTIAL HEATING PEIAND $\left(10^{12}\right.$ USABLE
BTU'S

$\therefore$

\begin{tabular}{cc}
.02 & 2,601 \\
$\frac{.002}{3.02}$ & 85 \\
\hline$\frac{.02}{2.686}$ & $\frac{275,367}{3.6}$
\end{tabular}

Colotado Diviston of Planning, Colorado Populacton Trends,

Hinter 1976 (population forecasts), U.S. Deparcment of Commerce,

Bureau of Census, Populacion Estimates and Projections, May, 1977

(population escimates), and Colorado Energy Conservation off ice

(residential heacing demand). 
ROUTT/STEAHBOAT HOT SPRINCS W0. 3/4 SITE DEVELOPMENT SCHEDULE

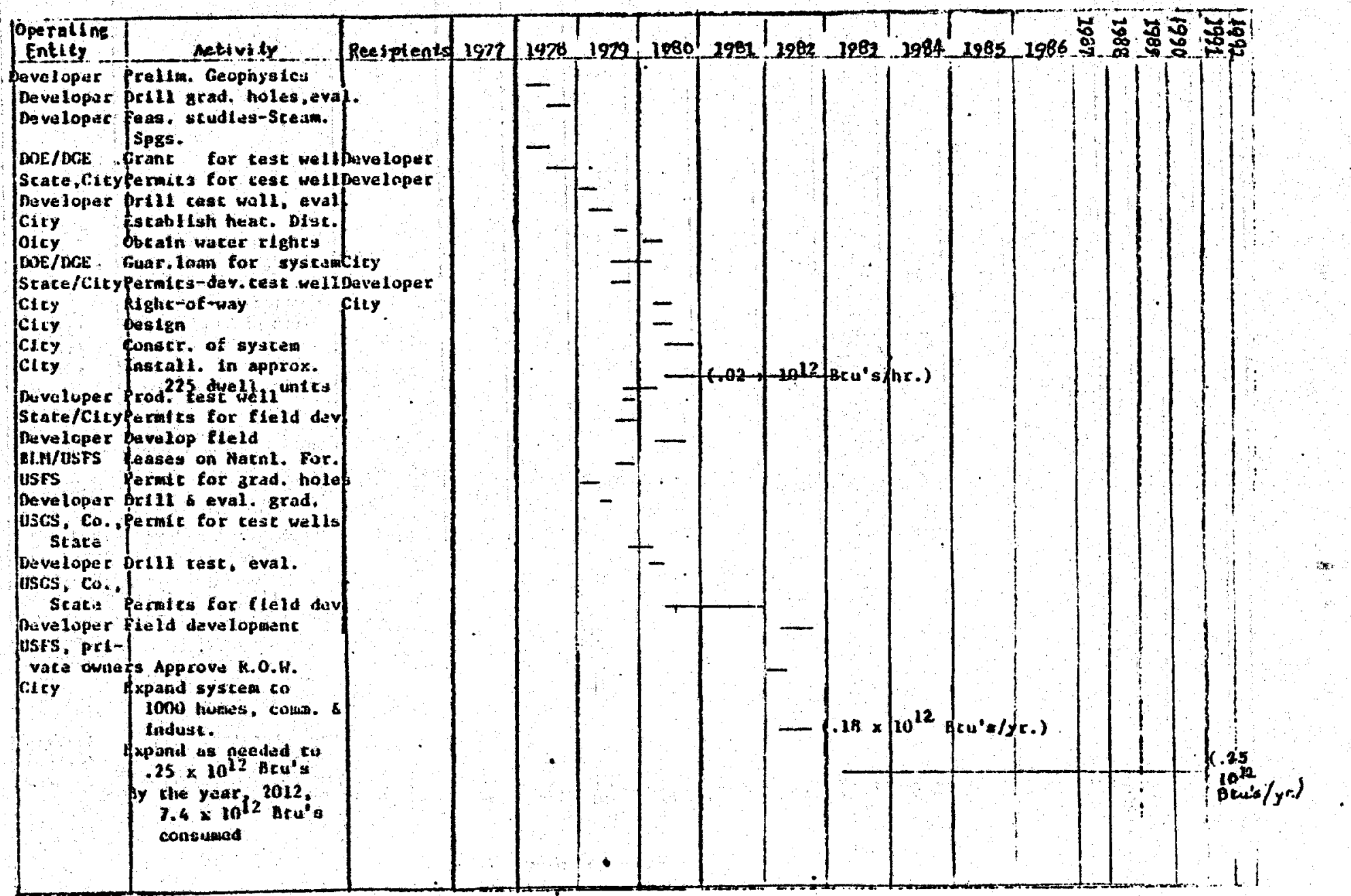


JUNTPER/CRAIG NO. $1 / 2$
SCENARIO FOR DEVELOFHEN

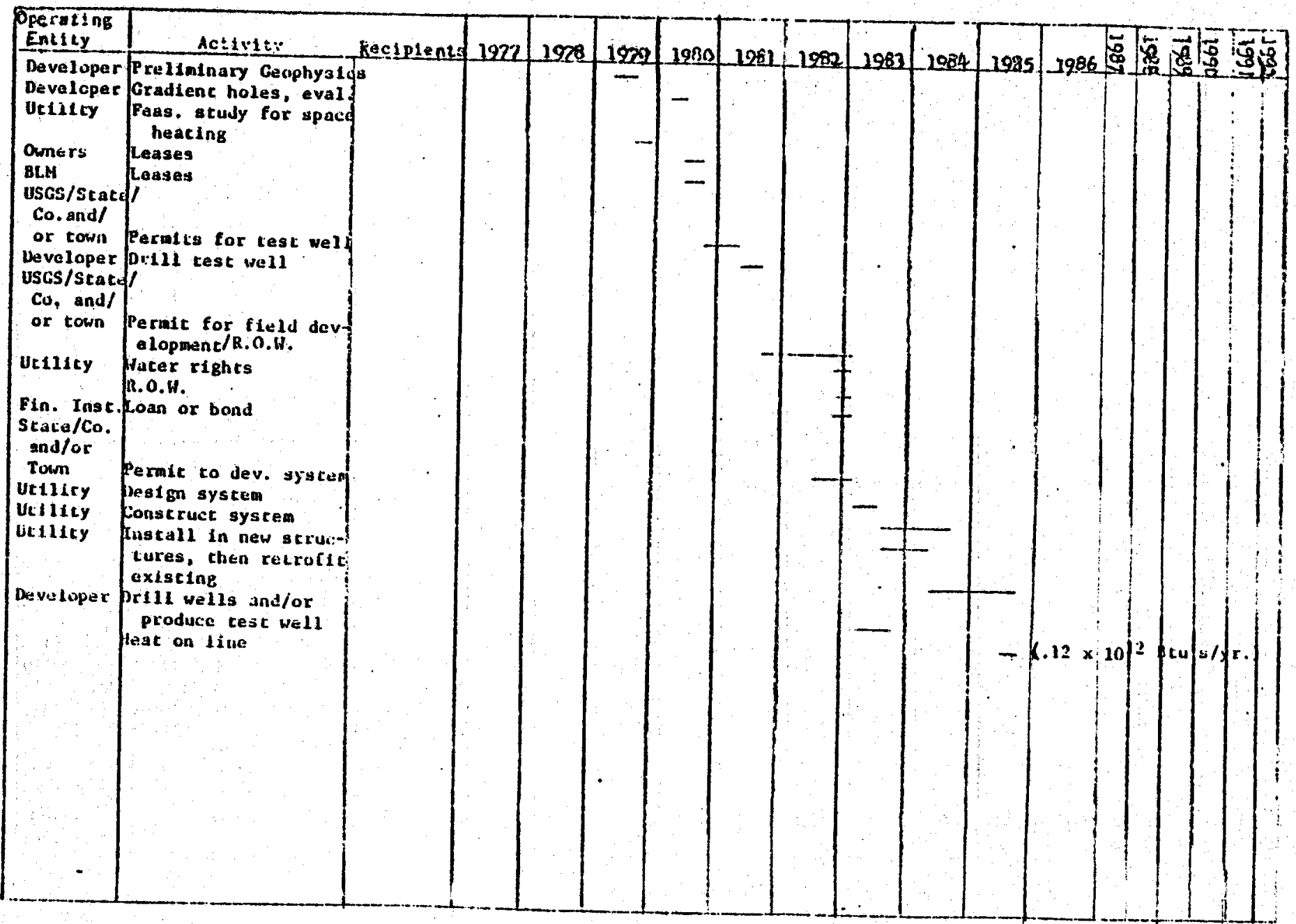




\section{NEVADA}

Nevada Drilling Activity

Temperature gradient holes continue to be drilled on private lands, and such activities are not recorded with federal and state agencies. Bureau of Land Management has recorded eight separate notices of Intent to carry out temperature gradient surverys for this quarter.

Phillips Petroleum Company has submitted a Plan of Operation to drill six geothermal test wells to a depth of $2438 \mathrm{~m} .\left(8000^{\prime}+\right.$ or $\left.-{ }^{\prime}\right)$ on federal leases in the Rye Patch Reservoir area, Pershing County, Nevada.

\section{Nevada Leasing Activity}

Eighty-six percent of the land in Nevada is federally administered. Less than $2 \%$ is state land. The remaining $12 \%$ is private land, most of which is owned by the rallroad.

Federa1 Lands

Natural Resource Land (public domain) is administered by the Bureau of Land Management and has leases totaling 881,971 acres (to February 1, 1978).

\section{RGRA's}

of the total federal acreage under lease, 152,662 acres are the KGRA leases. No new public sales were offered during this quarter. Competitive lease sales are being scheduled for later this year. Non-RGRA's As of February 1, 1978 there are 729,309 acres of nonKGRA federal leases. The geothermal leasing activity is 
variable, and can show from zero applications (February, 1978)

to over 30 applications during a single-month interval.

Again, this is a poor measurement of the geothermal potential and industry interest. 
Taken from: Competitive Lease Sale Action Schedule as of $1 / 9 / 78$

United states Geological Survey

Conservation Division

Office of the Area Geothermal Supervisor

Format C4 - Upcoming Sale Dates

Iocation

of KGRA
Latest

Sale Date

Scheduled
Original

Sale Date

Stillwater-soda Lake

Nv.

$7 / 18 / 78$

$3 / 22 / 78$

Gerlach NE, Gerlach

Nv.

$7 / 18 / 78$

$10 / 18 / 77$

Fly Ranch, Trego

Nv.

$7 / 18 / 78$

$12 / 13 / 77$

FIy Ranch Northeast Nv.

$7 / 18 / 78$

$12 / 14 / 77$

Double E.S., ElkO H.S. Nv.

$12 / 12 / 78$

$8 / 10 / 78$

Lease sale dates are tentative until public notice is issued 30 days prior to sale. 


\section{Environmental Assessment Reports from BLM}

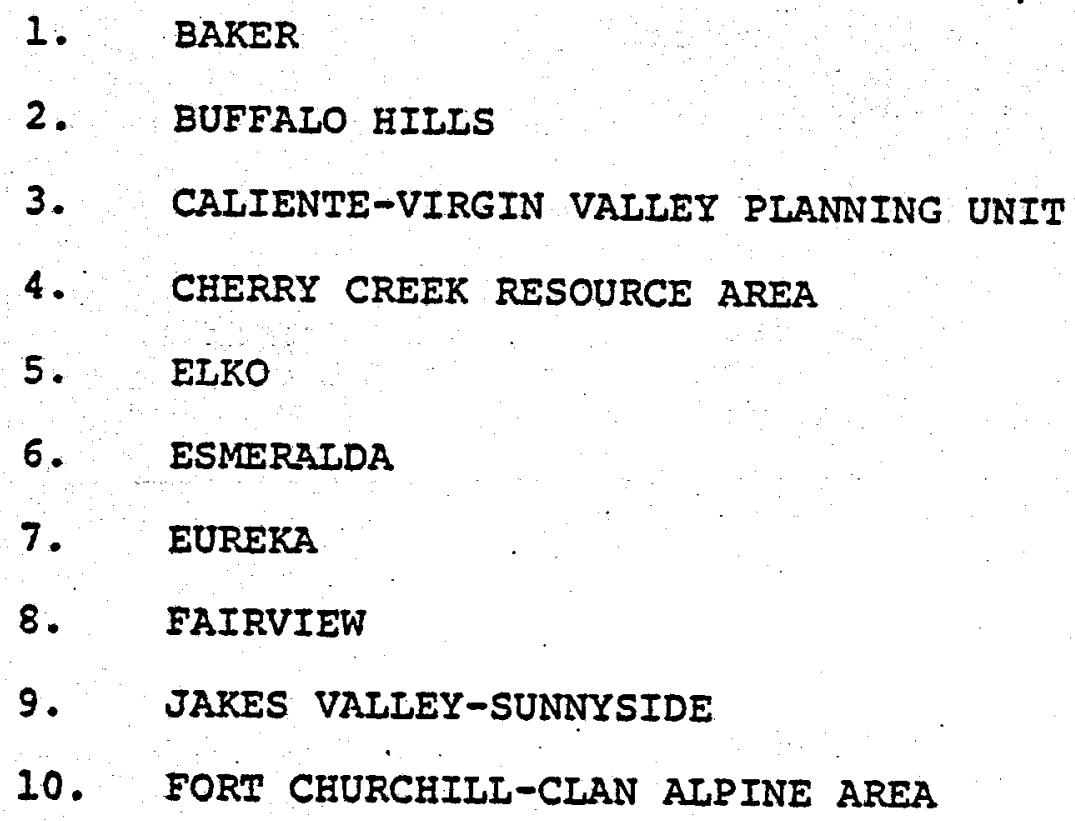




\section{NEW MEXICO}

\section{Geothermal Exploratory Activity}

The following 1s a list showing exploration activity as reported by the USGS and Salt Lake C1ty District Geothermal office, based on permits issued.

\section{Radium Springs}

Hunt Energy Co.: Electric resistivity survey, temperature gradient holes.

Chevron: Magneto-telluric surveys, temperature gradient wells, gravity survey.

Kilbourne Hole and Vicinlty

Geothermal Services: Eight temperature gradient holes : Hunt (Potrillo Mts.): Temperature gradient holes. Anadarko: Two gravity surveys, work completed, electric surveys, temperature gradient wells, to dril1 16-500' temperature gradient holes, to dri11 4-2000' temperature gradient holes, work not started. An additional 17 temperature gradient holes will be drilled off leased land. (Anadarko ran a "Gravity Survey" in this area.)

Phillips: S1x temperature gradient holes.

\section{Baca RGRA}

Phillips Petroleum Co.: To dr111 seven shallow temperature gradient holes, work not started.

Sandoval County

Sunoco: $1-500^{\prime}$ temperature gradient hole, no completion notice. 
Animas Valley

Amino11: Roving dipole survey, work completed.

Chevron (Lordsburg area): Dipole - dipole survey, eight temperature gradient wells at Lightning Dock.

Phillips: 19 temperature gradient wells.

Amax Exploration (Lightning Dock): 13 temperature gradient holes;

reenter oil well for temperature surveys; to drill four shallow

temperature gradient holes; one drilled already.

Socorro Area

Phillips: Eight gradient wells, work completed.

Sunoco Energy: 23 gradient wells on BLM, work completed.

Chevron: Dipole - dipole survey, gravity survey, 1-500' temperature

gradient hole, work completed.

Magdalena Area

Geo. Services: Four temperature gradient holes, no completion notice.

Hidalgo County

Chevron: Three temperature gradient wells.

Gila Hot Springs

Aninoil: Dipole and gravity surveys.

\section{Status of Geothermal Leasing}

The BLM Las Cruces Office has put out the final Environmental Assessment Record (EAR) and Technical Examination (TE) on proposed geothermal leasing in the Silver City area.

- The entire assessment area is $1,629,910$ acres, Including 280,300 acres of federal land, 585,790 acres of private land with federal minerals, and 55,603 acres of public land withdrawn for state aid. 
Non-competitive leases will be issued within thirty to sixty days. Lease applications have been filed by Southern Union ( 7500 acres) and Burmah 011 and Gas (4500 acres) In an area about twenty miles Northwest of Deming.

Federal Geothermal Leases issued in third quarter:

Radium Springs KGRA

Chevron: 1,227 acres

Texaco: 1,158 acres

Amino11: 1,235 acres

\section{Baca KGRA}

Amino11: 6,816 acres

Amax: $\quad 1,993$ acres.

No state lands have been put up for b1d since 1975 . The State Land office 1s walting for the leglslature to change the lease terms from a five to tenyear term before announcing further sales. 

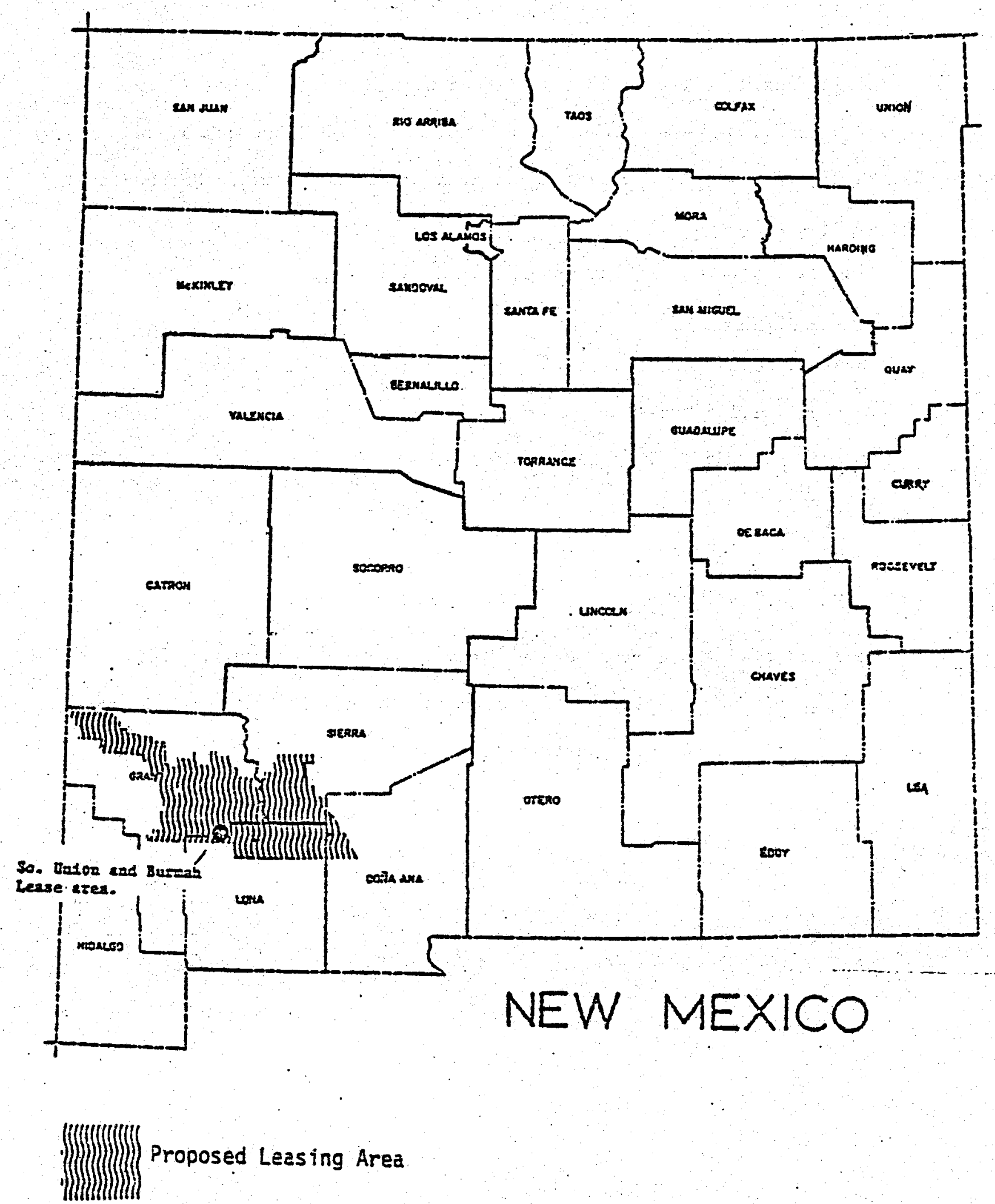

PROPOSED SILVER CITY GEOTHERMAL LEASING AREA

IN RELATION TO NEW MEXICO 
VAl.Les caldean SITE DEVELOTHENT SCHEDULE

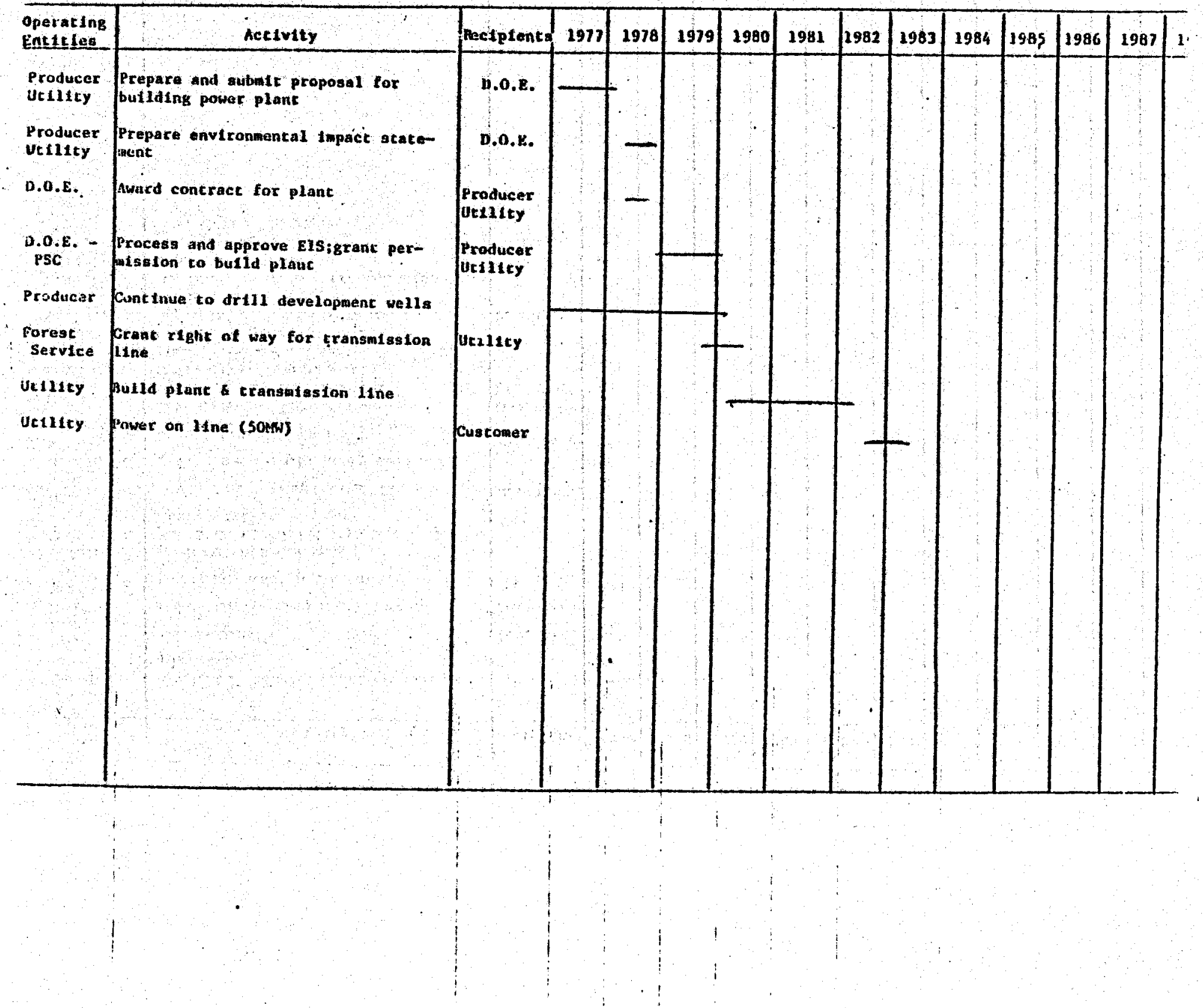


DEVELORMENT SCUNARIO FOR: KIHBOURNE HOIE - Electric - (State L Federal Land)

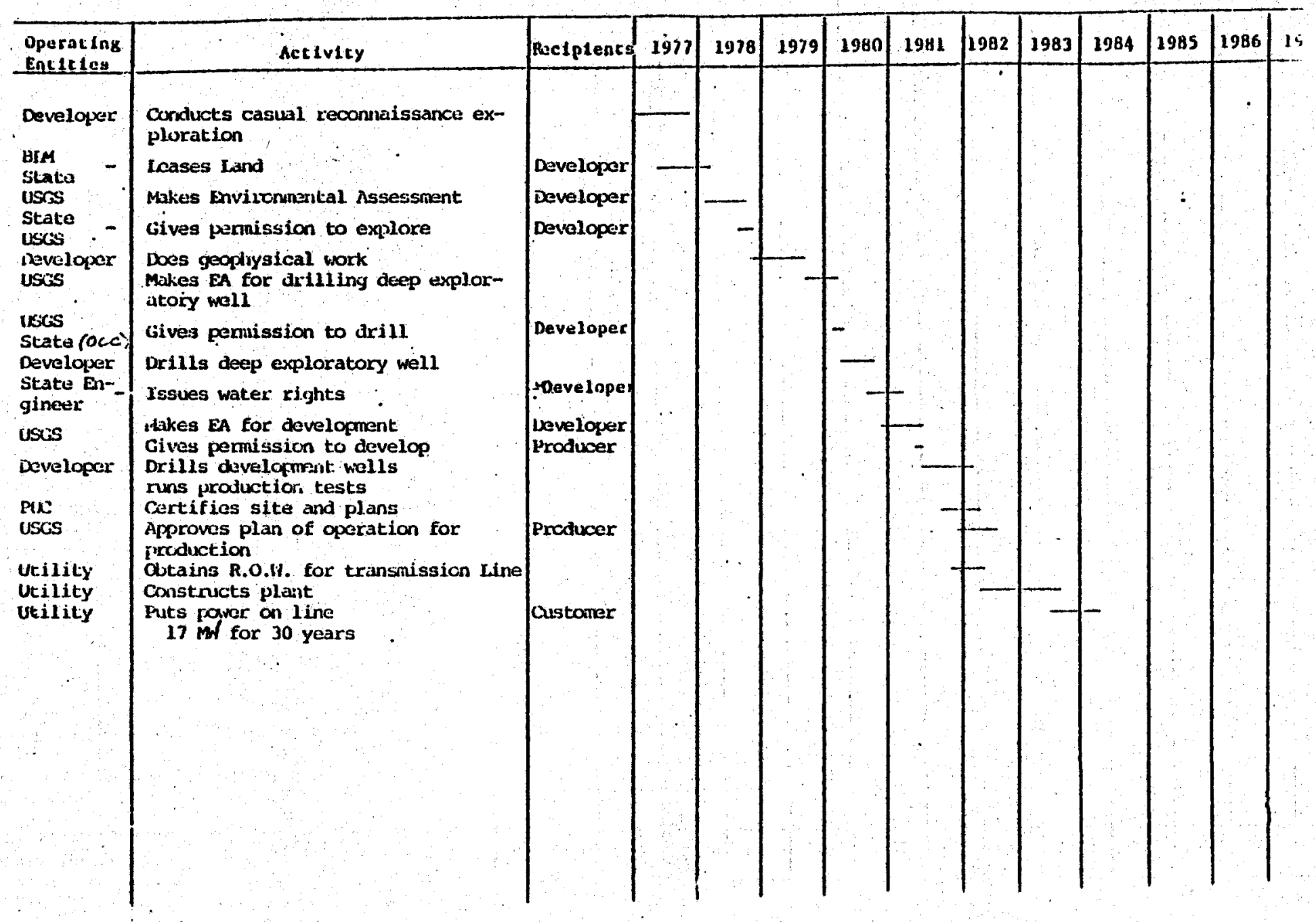




\section{UTAH}

GEOTHERMAL PROGRESS IN UTAH

Roosevelt Hot SprIngs Prospect

Financial Negotlations: Phillips Petroleum, Rogers Engineering, and Utah Power \& Light are now engaged in firm negotiations for a $52 \mathrm{Mm}$ power plant to come on line at the Roosevelt prospect in 1982. PhIllips will provide the production and infection wells. Rogers Engineering will design, build, and operate the gathering system and the plant, and Utah Power \& Light w1ll bulld the transmission line and buy and deliver the power. Power Plants: During February, 1978, plans for 52Mw power plants were presented to various state and federal agencies by both the PhIllipsRogers U.P. \& L. Group mentioned above and also by a consortium composed - of O'Brien Resources, Thermal Power Co., AMAX Exploration, and VTN. The latter consortium controls section 16 in the center of the prospect. Both plants are proposed to come on line in 1982. A cruclal question for both groups is that of unitization for the prospect.

Helical Screw Expander: Late in February, the Jet Propulsion Laboratory, In cooperation with Phillips Petroleum Co., set up the Helical screw Expander field test unit at the Roosevelt prospect. The unit w111 be tested at PhIllips well 54-3, whlch is presently part of a $100 \mathrm{~g}$ term reservolr test.

Hew We11s: During the third quarter, two deep geothermal test wells were completed and three more were begun. Republ1c Geothermal completed a well at Thermo which is being tested. Thermal Power Co. suspended a well at the Roosevelt Prospect. Wells are now being drilled by Getty 011 Co. (Roosevelt 
prospect), Union 0il (Cove Fort-Sulphurdale), and Hunt Oil Co. (Cove FortWhite Sages Flat). Several other wells are planned for later in the year.

\section{Direct Utilization}

Monroe, Utah: A proposal to inftiate a district heating scheme for Monroe, Utah was approved by the D.O.E. in February. The proposal was submitted by Monroe City with TerraTeck as technical advisor in response to the Program Opportunity Notice for Direct Utilization of Geothermal Energy-Field Experiments. The cost of the project, about $\$ 1.6$ million, will be shared by Monroe City and D.O.E.

Low Temperature Exploration: Investigation of potential low temperature prospects has been undertaken by the Utah Geological and Mineral Survey under the D.O.E. State Cooperative program. The exploration Involves primarily temperature gradient holes. Drilling has begun near Crystal Hot Springs in the southern Salt Lake Valley, and will later Include Midway Hot Springs, the Newcastle area, and the Beck's Springs--Wasatch Springs area north of Salt Lake City. 
ROOSEVELT HOT SPRINGS

Phillips Petroleum Co.

Therma 1 Power $\mathrm{Co}$.

Getty

\section{COVE FORT}

Union Oil CO.

Hunt Trust Estate

BERYL

McCulloch oil Co.

THERMO

Republic Goethermal

BOX ELDER COUNTY

Utah Power \& Light co.
3 wells, 1975

4 wells, 1975-76

2 wells, 1976

1 well, 1977

1 wel1, 1978

1 well, 1976

1 well, 1978

1 weาl, 1978

3 wells, 1976-77

1 well, 1976-77

1 we11, 1974
Currently Testing

2 Non-producers, 1 Collapsed Producible

Producible Suspended

Currently Drilling

Collapsed

Currently Drilling

Currently orilling

suspended

Abandoned 
FECERAL ANO STATE GEOTHERMAL LEASES

UTAH

(As of February 1, 1978)

\begin{tabular}{|c|c|c|c|c|c|c|}
\hline \multirow[b]{2}{*}{ Operator } & \multicolumn{4}{|c|}{$\begin{array}{c}\text { Feceral Leases } \\
\text { KGRA } \\
\text { Hon-kifien }\end{array}$} & \multicolumn{2}{|c|}{ Sta se Leases } \\
\hline & iio. & Acreace & עo. & Acreace & Ho. & Acrezge \\
\hline 1. Agri-Empire & 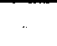 & & & & 4 & 3457.57 \\
\hline 2. Alta Energy Corporation & & & 1 & 1981.28 & 1. & 1367.52 \\
\hline 3. AMAX Exploration & & & 3 & 3808.78 & 12 & 8635.16 \\
\hline 4. American Geological Enterprises & & & 5 & 6339.69 & & . \\
\hline 5. American Geothermal Energy, Inc. & 3 & 7579.19 & & & & \\
\hline 6. American 0il Shale Corporation & & & & & 7 & 5566.46 \\
\hline 7. Aminotl USA, Ine. & 2 & 4067.46 & & & & \\
\hline 8. Anoco & & & 1 & 1923.19 & & \\
\hline 9. Anderson, Stephen & & & & & 3 & 3237.02 \\
\hline 10. Amstrong Dale E. & & & & & 1 & 760.00 \\
\hline 11. Atlantic Richfield & & & 7 & $11,735.63$ & & \\
\hline 12: Bames, Roy E. & & & & $\cdot$ & 4 & 2450.00 \\
\hline 13. Barr Ronald. $C$. & & & & & 6 & 3678.57 \\
\hline 14. Slankenship, Jack $\varepsilon$. & & & & & 1 & 1158.89 \\
\hline 15. Bountiful C1ty Corporation & & & 1 & 40.00 & & \\
\hline 16. Bradshaw, Melvin & & . & & & 2 & 90.32 \\
\hline 17. Brown, J.G. & & & & & 3 & $\$ 139.18$ \\
\hline 18. Cherron 011 Corporation & 1 & 2582.88 & 11 & 19.698 .65 & 16 & $13,963.31$ \\
\hline $\begin{array}{l}\text { 19. Christensen, L. Derai, and } \\
\text { Peterson, Hearid }\end{array}$ & & & & & 1 & 80.00 \\
\hline 20. Ciancane!li \& Gillett & & & 8 & $16,777.55$ & & \\
\hline 21. Ci inton $0: 1$ corporation & & & & & 1 & 538.32 \\
\hline 22. Colman, william J. & & & 3 & 5823.88 & & \\
\hline 23. Covello, J.H. & & & & & 5 & 3533.28 \\
\hline 24. Davon, Inc: & & & 5 & 7773.16 & & 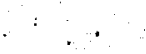 \\
\hline
\end{tabular}


FEDEPAL AHO STATE GEOTHERHAL LEASES

(As of February 1, 1978)

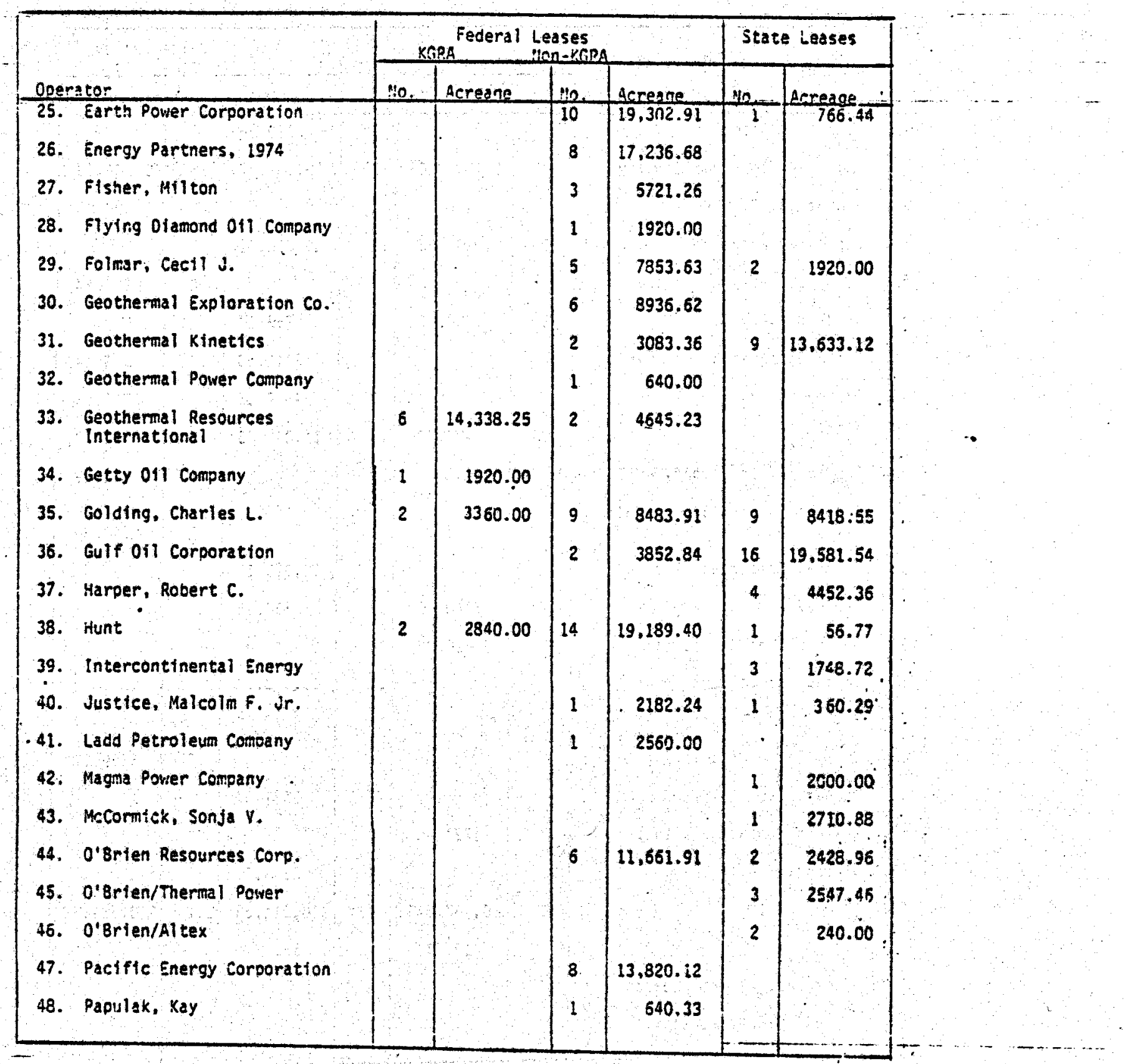


FEDERAL AMO STATE GEDTHER!HAL LEASES

(As of February 1,1978 )

\begin{tabular}{|c|c|c|c|c|c|c|}
\hline \multirow{2}{*}{ Ooerator } & \multicolumn{3}{|c|}{$\begin{array}{c}\text { Federal Leases } \\
\text { ropa }\end{array}$} & & \multicolumn{2}{|c|}{ Siate Leases } \\
\hline & an. & Acreace & $\mathrm{MO}$ & Acreage & $\mathrm{NO}$ & Acreage. \\
\hline 49. Papulak, Hilan S. & & & 3 & 7360.86 & & \\
\hline 50. Phillips Petroleum Company & 10 & $17,688.965$ & 12 & $16,589.87$ & 65 & $69,869.63$ \\
\hline 51. Pucket, R. E. & & & & & 1 & 1000.00 \\
\hline 52. Republic Geothermal & 1 & 1200.58 & 15 & $29,768.77$ & & \\
\hline 53. Resource Leasing Corporation & $\because$ & & & & 2 & 1293.44 \\
\hline 54. Seltzer, Gary W. & 1 & 1200.00 & 3 & 5759.37 & & \\
\hline 55. Steam Corporation of America & & & 2 & 3415.50 & 4 & 1886.14 \\
\hline 56. Stevenson & & & 3 & 4547.85 & $3-$ & 1763.53 \\
\hline 57. Supron & 3 & 5486.79 & 5 & 11.042 .86 & 5 & 2623.32 \\
\hline 58. Thermal Power Company & & $\cdots$ & & & 11 & 11.613 .89 \\
\hline $\begin{array}{l}\text { 59. Thermal Power/O'Brien/AMAX/ } \\
\text { (VTN) }\end{array}$ & & . & & $\cdot$ & 1 & 640.00 \\
\hline 60. Thermal Resources, Inc. & & $\therefore$ & 6 & $12,323.11$ & & \\
\hline 61. Thermex & 2 & 3840.00 & 2 & 3737.65 & & \\
\hline 62. Union gil of Californta & 14 & $18,620.98$ & 6 & 5037.90 & & \\
\hline 63. United States Geothermal Corp. & & . & 11 & $20,982.64$ & & \\
\hline 64. Utah International & & & 1 & $\cdot 2077.00$ & & \\
\hline 85. ป. Y. Industries & & & & & 7 & 6259.02 \\
\hline 66. Weiner, Ted & & & 1 & 1381.00 & & \\
\hline 67. Hestern Geothermal, Ine. & 2 & 1721.95 & & & & \\
\hline 58. Windsor, Trevar L. & & & 4 & 8348.72 & & \\
\hline TOTAL & 50 & $86,447.045$ & 199 & $340,011.35$ & 221 & $210,569 . \varepsilon 6$ \\
\hline$\cdots$ & & $13.6 \%$ & & $53.4 \%$ & & $33.0 \%$ \\
\hline Total state and Federal Lesses & & & & & & \\
\hline 637.028 .04 acres & & & & & & \\
\hline
\end{tabular}




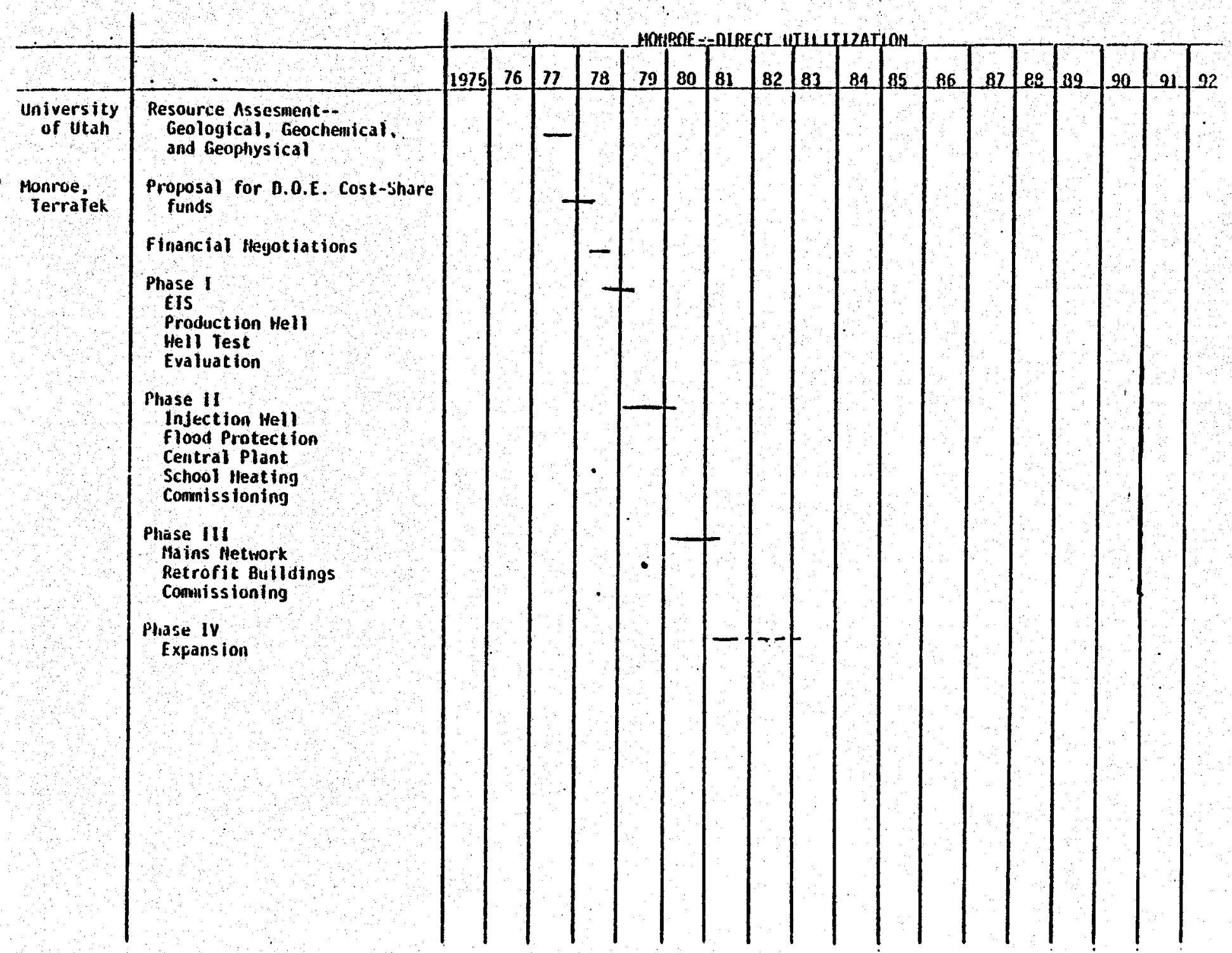




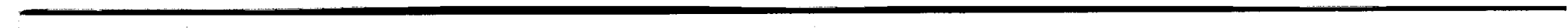

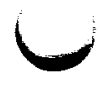

$\mathcal{U}$ $\checkmark$ 
REFERENCES

Bechtel Corporation, Advanced Design and Economic Considerations for Commercial Geothermal Power Plants at Heber and Niland, California. SAN-1124-2, San Francisco, CA, 1977.

C. H. Bloomster, GEOCOST: A Computer Program for Geothermal Cost Analysis. BNWL-1888, Battelie, Pacific Northwest Laboratories, Richland, WA, 1975.

C. H, Bloomster, L. L. Fassbender, and C. L. McDona1d, Geothermal Energy Potentlal for District and Process Heating Applications in the U.S. An Economic Analysis. BNWL-2311, Battelle, Pacific Northwest Laboratories, R1chland, WA, 1977.

N. Dalkey, The Delphi Method: An Experimental Study of Group Opinion, RAND R-5888-PR, 1969.

S. S. Einarsson, Geothermal Space Heating and Cooling, Second United Nations Symposium on the Development and Use of Geothermal Resources, San Francisco, May 1975.

0. G. Farah, and F. W1lliams, Methodology for Ranking Geothermal Reservolrs in Nonelectric Industrial Applications. MTR-7241, MITRE Corporation, McLean, VA, 1976.

R. Grieder, Economic Considerations for Geothermal Exploration in the Western United States, Symposium - Geothermal Energy, Colorado Geological Survey, Denver, Colorado, 1973.

C. L. McDonald and C. H. Bloomster, The Geocity Model: Description and Applicat1on. BNWL-SA-6343, Battelle, Pac1fic Northwest Laboratories, Richland, WA, 1977.

C. L. McDonald, C. E. Bloomster and S. C. Schulte, GOECITY: A Computer Code for Calculating Costs of District Heating Using Geothermal Resources. BNWL-2208, Battelle, Pacific Northwest Laboratories, RIchland, WA, 1977.

G. Ramachandran, Economic Analyses of Geothermal Energy Development in California. SAN-115P108-1 (V01. 1), Stanford Research Institute, Menlo Park, CA, 1977.

G. M. Relstad, Analysis of Potential Nonelectrlc Applications of Geothermal Energy and Their Place in National Economy - UCRL-51747, Lawrence Livermore Laboratory, Berkeley, CA, 1975.

C. R. Schuller, A. H. Schilling, R. J. Cole, and G, D. Simon, Legal, Institutional, and Political Problems in Producing Electric Power from Geothermal Resources in Callfornia. Battelle Research Report, August 1976. 
G.M. Simmons, Economics and Projections for Geothermal Development in the Northwest. Geothermal Energy Magazine, Vo1. 5, No. 10, December 1977.

R.K. Trehan, et. al., Analysis of Geothermal Energy Development Scenarios. MTR-7220, MITRE Corporation, McLean, VA, 1976.

R.R. Trehan, J.G. Leigh, and S. Pond, Economic Analysis and Benefit Assessment of the Federal Geothermal Energy Program. MTR-7326, MITRE Corp., McLean, VA, 1976.

D.E. White and D.L. Williams, eds., Assessment of Geothermal Resources of the United States. U.S. Geological Survey Circular 726, 1975. 
APPENDIX A

ASSESSMENT OF GEOTHERMAL SITES

Four different assessments of prospective geothermal sites are being prepared for the five-state area. The rationale for multiple assessments is to permit scenario development on the basis of resource assessments that range from ultra conservative to somewhat optimistic. In all cases, however, the areas selected for assessment as well as the assignment of a subsurface reservolr temperature are based on actual data. It is not assumed that only a portion of existing resources have been discovered. Primary emphasis is placed on moderate $\left(>90^{\circ} \mathrm{C}\right)$ to high $\left(>150^{\circ}\right)$ temperature reservoliss although low temperature areas are included if hot springs are lnvolved. Not included are the more then 5,000 wells within the five-state area which meet the D.0.E requirement for low temperature potential $\left(>20^{\circ}\right)$. The assessment procedure is the same as employed by the USGS in preparation of Circular 726. The detalls of the four assessments are sumarized below.

1. Assessment (1) is based almost totally upon the reservoir temperatures published 1n USGS Circular 726. In one or two instances, prospective areas have been demoted to "Iow temperature" status if the geochemical temperatures from hot spring waters are not appreclably above reglonal background. The USGS effort is both conservative and based upor a substantial research effort. Thus, this ranking gives a rellable minimum assessment of geothermal resources in the five-state area.

2. Assessment (2) is similar to assessment (1) except that considerable new information is utilized that was not avaliable when Circular 726 was published. These new data come from the state teams and from geothermal reports published after 1975. This assessment is essentlally an update of Circular 726. Assessment (2) appears on pages $113-127$. 
3. Assessment (3) will be similar to assessment (2) except that information from USGS WATSTORE file has been added. The general approach is to examine the 15,000 odd chemical analyses from the five-state area, calculate the various geothermal parameters, define norms and standard deviations for each parameter, and then assume that waters which appear to be of geothermal origin on the basis of 3 or more parameters actually represent geothermal prospects. This assessment adds between 20 and $50 \%$ more resources than assessment (2).

4. Assessment (4) will be the most optimistic. The preceding assessments utilize the conservative approach of assigning a subsurface temperature on the basis of the lowest geochemical temperature which is almost always the silica geothermometer. For assessment (4), mixing models are employed to raise the silica geotemperature, and the effect of magnesium on the $\mathrm{Na}-\mathrm{K}-\mathrm{Ca}$ geothermometer is examined. The total number of areas assessment is similar to assessment (3) but their predicted subsurface temperatures will be substantially elevated. In all cases, geothermal areas ylelding subsurface temperature estimates lower than $90^{\circ} \mathrm{C}$ are treated as "Low Temperature" resources and are assessed according to surface discharge temperatures. 


\section{Assessment (2)}

\section{ARIZONA}

Name

Power Ranch Wells

Clifton H.S.

Verde H.S.

Gillard H.S.

Eagle Creek H.S.

Coolidge H:S.

Coffers H.S.

Cat Tank

Javelina Peak

Safford area

Indian H.S.

Castle H.S.
Lat

Long

11141.2

10917.9

11142.5

$109: 20.9$

10926.4

11031.7

11334.5

10922.7

10925.6

10933.6

10954.0

11221.7
Estimated Temperature

$\left({ }^{\circ} \mathrm{C}\right)$

184

160

150

140

130

120

120

115

110

.110

105

105 


\section{ARIZONA}

- Name

Coolidge area

Radium Springs

Hookers H.S.

Buckhorn area

Aqua Caliente

Artesian H.W

MT Graham

Lucats Spr.

Palomas Mts.

Baragan Mountain

Theba

Bowie area

Mobil area

Artesia area

Warm Spr.
Lat .

Long

3254.2

3244.4

- 3220.2

3325

3259.6

3243.1

3251.8

3244.7

33. 0.0

$\begin{array}{ll}33 & 6.7\end{array}$

3255.4

3219.1

3312.2

3241.0

$33 \quad 4.3$
11134.0

$114 \quad 4.2$

11014.3

11142.2

11318.3

10942.5

10944.9

10944.7

11330.5

11324.5

11245.1

10929.0

11221.9

10942.3

10959.0
Measured

Temperature

$\left({ }^{\circ} \mathrm{C}\right)$

61

$>50$

53

49

46

44

44

42

42

39

38

36

35

33

32 


\section{COLORADO}

Name

Lat.

Long.

374515

383050

Waunita Hot Springs

Splashland Hot Water Well 372919

Sand Dunes Hot Water Well 374642

Penny Hot Springs

$3913 \quad 33$

Routt Hot Springs

403334

385100

374106

382949

3715.55

374120

3913.9

301626

374501

3932

Glenwood Area

384359

394420

$40 \quad 2902$

Steamboat Springs

Don K Ranch Artisian Well 381020

Trimble Hot Springs

372328

372330
$108 \quad 0753$

1063027

1055127

1055120

1071328

1065100

1080311

1064947

1060437

1070037

1080145

10713.5

$107 \quad 0554$

1061901

10719

1061026

1053043

1065023

1050032

1075052

1075052
Estimated

Temperature

$\left({ }^{\circ} \mathrm{C}\right)$

200

160

160

160

150

145

140

140

140

i40

140

140

135

130

130

120

120

120

110

110

110 
(HIGH TEMPERATURE)

(Continued)

\begin{tabular}{|c|c|c|c|}
\hline & & & \\
\hline Name & Lat. & Long. & $\begin{array}{c}\text { Temperature } \\
\left({ }^{\circ} \mathrm{C}\right)\end{array}$ \\
\hline
\end{tabular}

South Canyon Hot Springs 393315

107.2351

105

Geyser Warm Springs

$3744 \quad 48$

1080702

105

Hartsel Hot Springs

390105

1054740

105

Orvis Hot Springs

380759

1074401

105

Cottonwood Springs

$38 \quad 48 \quad 40$

1061320

105

Mineral Hot Springs

381008

1055505

105

Pinkerton Hot Springs

$37 \quad 2650$

$10748 \quad 17$

100

Hot Sulphur Springs

400433

1060644

95

Craig Warm Water Well

403006

1073304

90

Colonel Chinn Hot Water

$3852 \quad 23$

1073804

80 Well 
(LOW. TEMPERATURE)

\section{COLORADO}

Name

Lat.

370010 Well

Ourey area

Dunton Hot Springs

Brands Ranch Artesian Well

Rainbow Hot Springs

Canon City Hot Springs

Eoff Artesian Well

Juniper Hot Spring

Conundrum Hot Springs

Valley View Hot Springs

Fremont Hot Springs

382738

Wellsville Warm Springs

Antelope Warm Springs

$37 \quad 4436$

Dotsero Warm Springs

393739

Birdsie Warm Springs

$37 \quad 4436$

Florence Artesian Well

382453

Haystack Butte Warm Water 400548 Well

Swissvale Warm Springs

Ranger Warm Springs

$38 \quad 2849$

$3848 \quad 57$

Stinking Spring

37.0205

El Dorado Spring
$3955 \quad 52$
Long.

$106 \quad 4703$

1074003

69

1080538

44

1063205

42

1065652

40

$105 \quad 15 \quad 46$

40

1065936

39

$10757 \quad 10$

38

1065326

38

1054849

37

1051146

36

$105 \quad 5436$

33

1070214

32

1070622

32

1070214

30

1050243

28

1051416

28

1055325

28

1065228

27

1064825

27

1051646

70

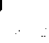


(Continued)

\section{COLORADO}

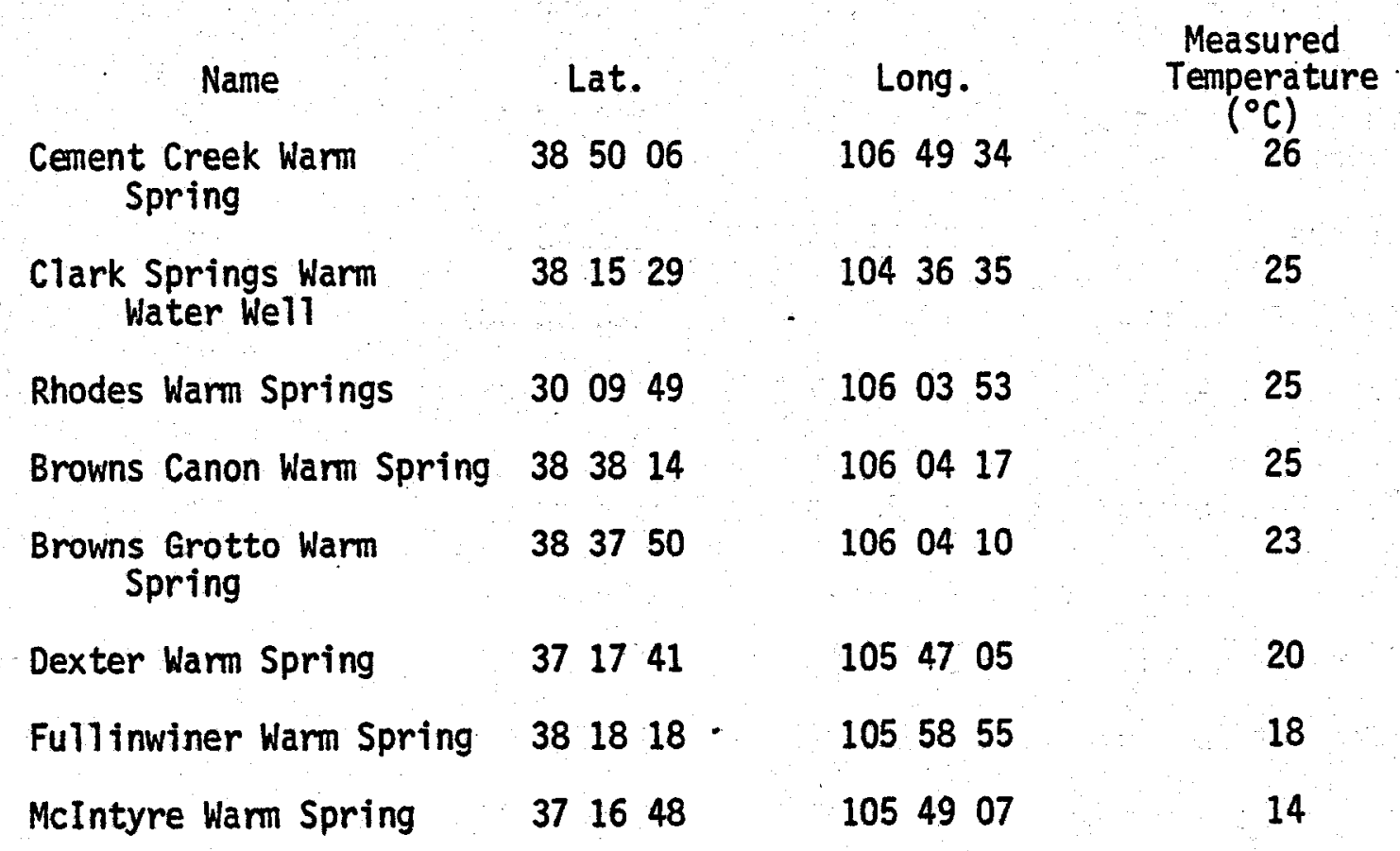




\section{NEVADA}

\begin{tabular}{|c|c|c|c|}
\hline Name & Lat. & Long. & $\begin{array}{l}\text { Estima ted } \\
\text { Tempera ture } \\
\left({ }^{\circ} \mathrm{C}\right)\end{array}$ \\
\hline Beowawe H.S. & 4034.2 & 11634.8 & 240 \\
\hline Brady H.S. & 3947.2 & 11900 & 214 \\
\hline Steamboat Spr. & 3923 & 11945 & 210 \\
\hline Sun Emidu Desert & \multicolumn{2}{|c|}{ (SEC. $9+16$ T29N R 23E) } & 200 \\
\hline Sulphur H.S. & 4035.2 & 11517.1 & 140 \\
\hline Kyle H.S. & 4024.5 & 11752.9 & 190 \\
\hline Jersey Valley H.S. & $40 \quad 10.7$ & 11729.4 & 185 \\
\hline Hot Sulphur Spr. & 4128.2 & 11609.0 & 180 \\
\hline Hot Spr, near wells & $41 \quad 10.9$ & 114.59 .4 & 180 \\
\hline Hot Spr. Ranch & 4045.7 & 11729.5 & 180 \\
\hline Lee H.S. & 3912.6 & 11843.4 & 175 \\
\hline Pinto H.S. & 4121 & 11847 & 175 \\
\hline Great Boiling H.S. & 4039.7 & 11921.7 & 170 \\
\hline Leach H.S. & 4036.2 & 11738.7 & 170 \\
\hline Fernley H.S. & \multicolumn{3}{|c|}{ (SW $\frac{1}{4}$ SEC $18 T$ TON R 26E) } \\
\hline Baltizore H.S. & 4155.3 & 11842.7 & 170 \\
\hline Soda Lake & 3934 & 11849 & 165 \\
\hline Stillwater flowing well & 3931.3 & 11833.1 & 165 \\
\hline Smith Cr Valley & 3921.4 & 11732.8 & 160 \\
\hline Wabuska H.S. & $\begin{array}{lll}39 & 09.7\end{array}$ & 11911 & 155 \\
\hline Needle Rocks & 4008.8 & 08.8 & 150 \\
\hline
\end{tabular}


(HIGH TEMPERATURE)

\section{NEVADA}

\begin{tabular}{|c|c|c|c|}
\hline Name & Lat. & Long. & $\begin{array}{l}\text { Estimated } \\
\text { Temperature } \\
\left({ }^{\circ} \mathrm{C}\right)\end{array}$ \\
\hline Black Rock Dessert & 4057 & 11858 & 150 \\
\hline Dixie Valley H.S. & 3947.9 & 11804.0 & 150 \\
\hline Double H.S. & 4103.0 & 11902.8 & 145 \\
\hline Darrough H.S. & 3849.3 & 11710.8 & 140 \\
\hline Dyke H.S. & 4134.0 & 11833.7 & 140 \\
\hline Hot Sulphur Spr. & 419.4 & 11459.1 & 140 \\
\hline We11 near Gerlach & (SEC 10 T32N & R23E) & 135 \\
\hline Howard H.S. & 4143.3 & 11830.3 & 130 \\
\hline Cherry Cr. H.S. & \multicolumn{2}{|c|}{ (SEC 6 T23N R63E) } & 130 \\
\hline Buffalo Valley H.S. & 4022.1 & 11719.5 & 130 \\
\hline Hot Pot & 4055.3 & 11706.5 & 130 \\
\hline Fly Ranch & 4052.0 & 11920.9 & 130 \\
\hline Mineral H.S. & 4147.3 & 11443.3 & 130 \\
\hline H.S. near Trebo & 4646 & 11907 & 130 \\
\hline Butte Spr. & 4046 & 11907 & 130 \\
\hline Spencer H.S. & 3919 & 11651 & 125 \\
\hline Hot Spr. Point & 4024.2 & 11631.0 & 125 \\
\hline Near Golcande & 4057.7 & 11729.6 & 125 \\
\hline Bartholomae & 3924.3 & 11620.8 & 125 \\
\hline Warm Spr. & $38 \quad 11.3$ & 11622.5 & 120 \\
\hline Hyder H.S. - & \multicolumn{2}{|c|}{ (SEC 28 T25N R38E) } & 120 \\
\hline Sou H.S. & 4005.4 & 11743.5 & 115 \\
\hline
\end{tabular}


NEVADA

Name

ETko H.S.

The Hot Springs

Soda Spr.

Valley of the Moon

Wild Horse Res.

Lower Ranch
Lat.

Long.

4049.1

4125.4

(SEC 29 T6N R35E)

11546.5

11723.0

(SEC 23 T27N R43E)

(SEC 4 T43N R55E)

(SEC 16 T25N R39E)
Estimated Temperature ( C)

\section{5}

110 105 100 100 100 


\section{NEVADA}

Name

Monte Neva H.S.

Near Carlin

Walti H:S.

Near Ruby Marsh

Walleys (Genoa) H.S.

Nevada H.S.

Diana Punch Bowl

Soldier Meadows

B06 H.S.

Bowers H.S.

Potts Ranch H.S.

Nile Spr.

SSE Patsville
Lat.

Long.

(SEC 24 T21N R63E)

11608.0

11635.2

3954.1

(SEC 2 T27N R58E)

3858.9

11949.9

11924.7

61

(SEC 22 T14N R47E)

59

-

4155.5

11913.2

11848.1

(SEC 3 T16N R19E)

(SEC 2 TI4N R47E)

45

(SEC 30 T47N R7OE)

43

4105

11555

79

72

65

61

54

54

46

41
Estimated

$\left({ }^{\circ} \mathrm{C}\right)$ 
NEW MEXICO

\begin{tabular}{|c|c|c|}
\hline Name & Lat. & $\begin{array}{l}\text { Estimated } \\
\text { Temperature } \\
\text { (OC) }\end{array}$ \\
\hline Valles Caldera & 10632 & 240 \\
\hline Lightning Dock & 10850 & 170 \\
\hline Kilbourne Hole & Doña Ana & 155 \\
\hline Lower San Francisco H.S. & Gila & 150 \\
\hline Radium Springs & Las Cruces & 130 \\
\hline Ojo Caliente & Jemez & 130 \\
\hline Montezuma H.S. & Las Vegas & 130 \\
\hline Mamby's H.S. & Taos & 120 \\
\hline White Sands (Town) & Tularosa & 120 \\
\hline Mesquite Area & Doña Ana & 120 \\
\hline Las Alturas. & Las Cruces & 120 \\
\hline Guadalupe Springs & Mt. Taylor Area & 120 \\
\hline Ponce de Leon Spr. & Santa $\mathrm{Fe}^{-}$ & 105 \\
\hline Truth or Consequences & $T$ or $C$ & 100 \\
\hline Hot Well & Jemez & 100 \\
\hline West Mesa - Black Mtn. & & 95 \\
\hline Derry Warm Spr. & North of Las Cruces & 90 \\
\hline San Ysidro & Jemez & 80 \\
\hline
\end{tabular}


NEW MEXICO

Name Lat. Long.

Gila.

Near Texas Border

Gila

66

Gila H.S. (Middle Fork) Gila

65

Closson

?

Gila

61

Mimbres H.S.

Jemez

Gila

?

Prewitt Area

Gila H.S. (Below Bridge)

Gila

Jemez

?

Tohatchi Area

Upper San Francisco H.S. Gila

?

Crown Point Area

Gila H.S. (Upper Mid Fork)Gila

Eastern San Augustin Plain

Socorro Area (Sedi110 Spr.)

McCauley Spr.

Jemez

Gila

Cliff Area

Playas Valley

SW New Mexico

71

58

56

54

46

44

42

39

37

37

36

35

34

32

31

28
Measured Temperature

$\left({ }^{\circ} \mathrm{C}\right)$ 
UTAH

Name Lat. Long. Lstimated

\begin{tabular}{|c|c|c|}
\hline Roosevelt H.S. & $(C-26-9) 34$ & 250 \\
\hline Cove Fort - Sulphurdale & $3836 \quad 11233$ & 200 \\
\hline Thermo H.S. & $(C-30-12) 21$ & 185 \\
\hline Joseph H.S. & $(C-25-4) \quad 23$ & 140 \\
\hline Red Hill H.S. & $(C-25-3) 11$ & 135 \\
\hline Crystal H.S. & $(C-4-1) 11$ & 135 \\
\hline Abraham H.S. & $(C-14-8) 10$ & 125 \\
\hline Wasatch H.S. & $(B-1-1) 25$ & 120 \\
\hline Monroe (cooper) H.S. & $(C-25-3) 10$ & 120 \\
\hline Obden H.S. & $(B-6-1) 23$ & 110 \\
\hline Stinking Springs & $(B-10-3) 30$ & 110 \\
\hline Meadow H.S. & $(C-22-6) \cdot 26$ & 105 \\
\hline Hooper H.S. & $(B-5-3) 27$ & 105 \\
\hline Utah H.S. & $(B-7-2) 14$ & 95 \\
\hline Becks H.S. & $(B-1-1) 14$ & 90 \\
\hline Crystal H.S. & $(B-11-2) 29$ & 90 \\
\hline
\end{tabular}


UTAH

Name Lat. Long. $\quad \begin{gathered}\text { Measured } \\ \text { Temperature } \\ \left({ }^{\circ} \mathrm{C}\right)\end{gathered}$

\begin{tabular}{lll} 
Wilson H.S. & $(C-10-14) 33$ & 61 \\
Midway H.S. & $(D-3-4) 26$ & 45 \\
Saratoga H.S. & $(C-5-1) 25$ & 44 \\
Uddy H.S. & $(B-13-3) 23$ & 43 \\
Crater H.S. & $(C-5-1) 25$ & 43 \\
LaVerkin H.S. & $(C-41-13) 25$ & 42 \\
Veyo H.S. & $(C-40-16) 7$ & 42 \\
Unnamed H.S. & $(B-11-19) 11$ & 42 \\
Castilla H.S. & $(P-9-4) 18$ & 40 \\
Hatton H.S. & $(C-22-6) 35$ & 48 \\
Radium (Dotsons) H.S. & $(C-30-9) 7$ & 33 \\
Lincoln Point W.S. & $(D-8-1) 3$ & 32 \\
Split Mountain W.S. & $(D-4-24) 16$ & 30 \\
Fish Springs & $(C-11-14) 23$ & 28 \\
Gandy W.S. & $(C-15-19) 31$ & 27 \\
Morgans W.S. & $(C-5-5) 9$ & 27 \\
Blue W.S. & $(B-13-5) 29$ & 27 \\
Warm Spr. & $(B-12-15) 19$ & 27 \\
Warm Spr. & $(D-7-1) 5$ & 25 \\
Johnsons Warm Spr. & $(C-25-3) 27$ & 25 \\
Como H.S. & $(A-4-3) 31$ & 25 \\
Grantsville W.S. & $(C-2-6) 16$ & 27 \\
\hline
\end{tabular}




\begin{tabular}{|c|c|c|c|}
\hline \multicolumn{4}{|c|}{ UTAH } \\
\hline Name & Lat. & Long. & $\begin{array}{l}\text { Measured } \\
\text { Temperature } \\
\left({ }^{\circ} \mathrm{C}\right)\end{array}$ \\
\hline
\end{tabular}

$\begin{array}{lll}\text { Russels Warm Spr. } & (C-5-5) 17 & 22 \\ \text { Richfield W.S. } & (C-23-3) 26 & 22 \\ \text { Diamond Fork W.S. } & (D-8-5) 14 & 20 \\ \text { Goshen W.S. } & (D-10-1) 8 & 20 \\ \text { Sterling Spr. } & (D-19-2) 4 & 19 \\ \text { Big W.S. } & (C-1-7) 8+9 & 18\end{array}$




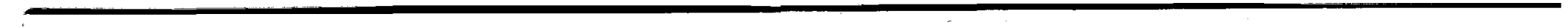

$\mathcal{U}$

$\checkmark$ 
APPENDIX B

A SIMULATION MODEL

FOR THE ECONOMIC ANALYSIS OF GEOTHERMAL RESOURCES

\section{Summary of Geothermal Algorithm - Electric Uses}

The model which follows posits the very simple economic idea that an investment should be made if the present value of all net income streams is equal to the investment required to generate them when discounted at an interest rate appropriately high. If the amount of an investment is known, and the net Income streams are known, the rate of return can be calculated. This model attempts to calculate the internal rate of return to a producer from a geothermal field for which electricity production is planned. This model can easily be modifled to fit any type of energy production from a geothermal field.

The basic equation is of the simple form for discounting cash flows:

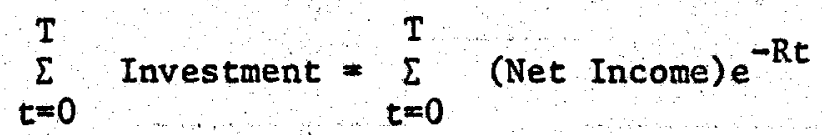

where Net Income - Total Revenues - Total Operating Cost - Taxes,

Total Revenues = (Price) (Quantity Output),

Total Operating Cost $=$ A Percentage of Investment.

All investment, revenue and cash flows are modeled for each year of the Iife of the profect. The program solves the resulting polynomial in $T$ roots for the only single-valued real root, which is the value of $R$. Because Investments are also modeled for each year of the project, they are, likewise, discounted to the present. The resulting equation is

$$
\sum_{t=0}^{T}\left(\text { Investment }- \text { Net Income) } e^{-R t}=0 .\right.
$$




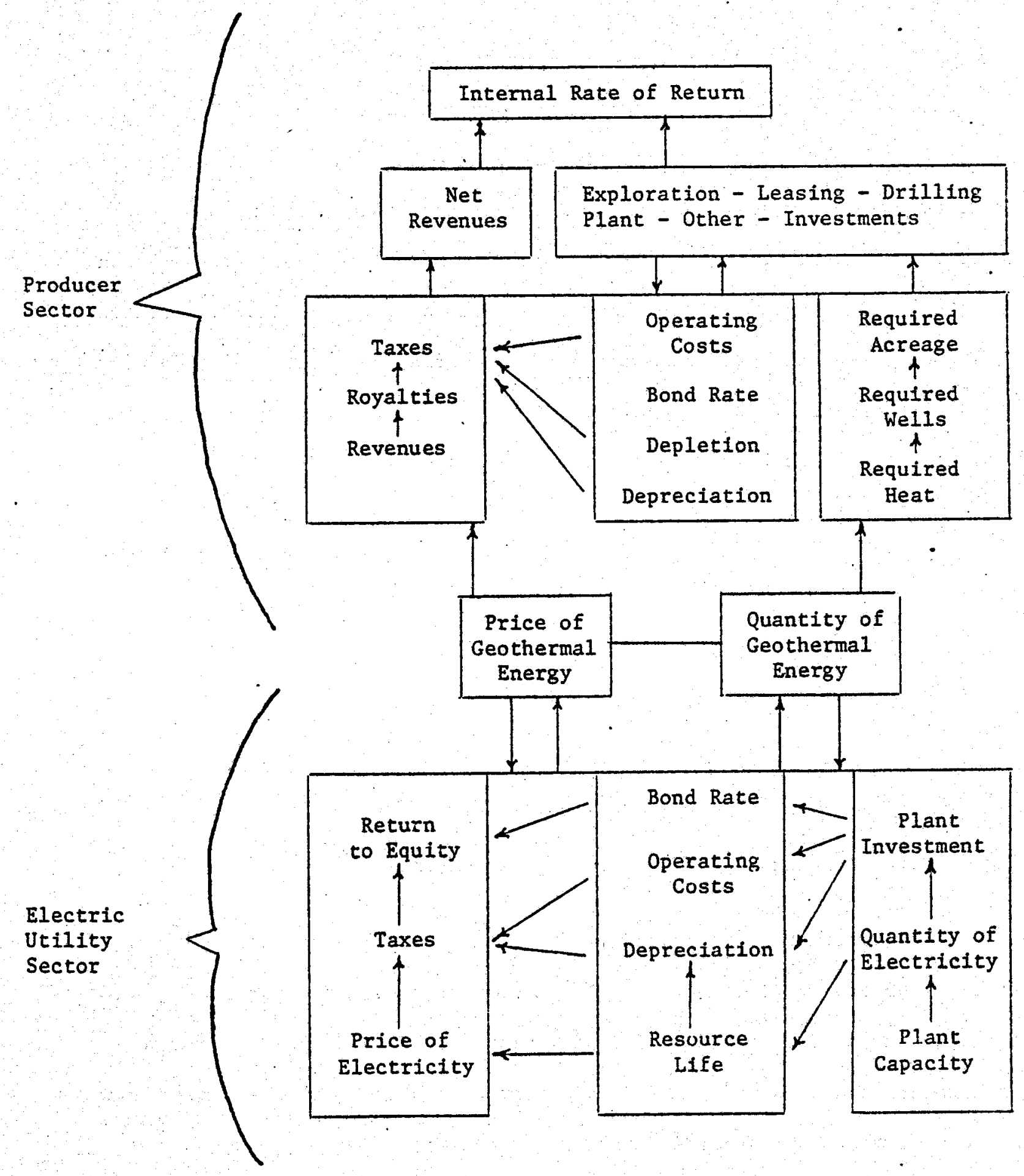


The Geothermal Internal Rate of Return

Algorithm (GIRORA) - Electric Uses

The following is a step-by-step description of the model, GIRORA.

GIRORA is a simulation model which can be used for sensitivity analysis and, therefore, for analyzing the effect of changing policy varlables on the profitability of developing geothermal energy for electric power production. Moreover, GIRORA-Electric is used to rank known geothermal resource sites according to their profitabllity for the producer of stesm or hot water. It is assumed that the geothermal resource is Ilquid-dominated.

As 1llustrated in the preceding diagram, the model has two sectors: one for the electric utility and one for the geothermal producer. As noted previously, the utimate ouput of the model is an internal rate of return for the producer. Taken as "givens" are the price of electricity and the regulated return to the electric utllity (return on equity holdings). The price of hot water is then the maximum price consistent with the price of electricity (busbar) and the utilfty's return to equity.

We begin, therefore, by describing the utlifty sector.

\section{Electric Utility Sector}

The model first identifies the principal components of cost to the electric utility for each year $(t)$ of electriclty production: capital costs $\left(\mathrm{CC}_{t}\right)$, operating costs (OMC $)$, Income taxes $\left(\mathrm{ITX}_{t}\right)$, property taxes $\left(\mathrm{PTX}_{t}\right)$, and energy costs $\left(\mathrm{ENC}_{t}\right)$.

Capital costs are a function the investment (K) required for a specifled level of capacity in kilowatts (CAP). 
(1) $\mathrm{K}=(\mathrm{CAP})(\mathrm{CAPC})$

CAPC: capacity cost in dollars per kw; an input parameter.

Capital costs are also a function of the regulated return to equity (ER), the bond rate (BR), the debt to equity ratio, and depreciation (DEPR ${ }_{t}$ ).
(2) $E=(E K)(K)(E R)$, equity costs,
(3) $D=(D K)(K)(B R)$, debt costs,
(4) $\operatorname{DEPR}_{t}=\left(\mathrm{DEP}_{t}\right)(\mathrm{K})$, depreciation;

and therefore

(5) $C C_{t}=E+D+D_{E P R}$ '

where, EK: equity share of capital; an input parameter,

DK: debt share of capital; an input parameter

$$
(E K=1-D K) \text {, }
$$

$D E P_{t}:$ depreciation rate in year $t$.

(6) $\operatorname{DEP}_{t}:(T+1-t) / \sum_{t=1}^{T} t$,

where $T$ is the length of time for electricity production. The model provides for a fast write-off option.

Operating costs are a function of total investment and escalate through time.

(7) $O M C_{t}=\left(O C_{t}\right)(K)$

(8) $O C_{L}=(O C B)(1+\dot{O C})^{t}$, 
$O C_{t}:$ operating percent of investment in year $t$; input variable, OCB: base rate; input variable, $\dot{O C}$ : escalation rate; input variable.

Likewise, property taxes are a function of investment.

(9) $\operatorname{PTX}=(\mathrm{PTP})(\mathrm{K})$,

PTP: property tax rate; input variable.

Before income taxes are calculated, total revenues must be known. They are, of course, a function of the price of electricity $\left(P E_{t}\right)$ and the quantity of electricity. $(Q E)$, which is a function of plant capacity. $\mathrm{PE}_{t}$ is specified as an exogenous busbar price of electricity which is determined by the market and escalates over time.

(10) $P E_{t}=(P B)(1+\dot{P})^{t}$,

$\mathrm{PB}$ : Base busbar price of electricity; input variable, $\dot{p}$ : escalation factor; Input variable.

(11) $Q E=(C A P)(8760)(L F)(1-U F)$

LF: Plant factor; an Input variable, UF: Plant use of power; an input variable.

Income taxes and energy costs must be determined simultaneously, because the price of the geothermal energy ( PHW $_{t}$ ) is an element of both and moreover, $\mathrm{PHW}_{t}$ is the output of the utflity sector for the model. The quantity of geothermal energy is determined by electricity plant requirements. 
(12) $\mathrm{QHW}=(\mathrm{CAP})(8760)(\mathrm{LF})$.

(13) $\mathrm{ENC}_{t}=\left(\mathrm{PHW}_{\mathrm{t}}\right)(\mathrm{QHW})$.

(14) $\operatorname{ITX}_{t}=\{\operatorname{TXRT}\}\left\{\left[\left(P E_{t}\right)(Q E)\right]-\left[O M C_{t}\right]-[P T X]-\left[E_{t}\right]\right.$.

$$
\left.-\left[\operatorname{DEPR}_{t}\right]\right\}-\left\{[\mathrm{CRRT}]\left[\mathrm{K}_{t=1, t=2, t=3}\right]\right\}
$$

TXRT: Income tax rate; input variable,

CRRT: investment tax credit rate; input variable.

Therefore,

(15) $\mathrm{PHW}_{t}=\frac{(\mathrm{TXRT})\left(\mathrm{DEPR}_{t}\right)+(\mathrm{CRRT})\left(\mathrm{K}_{t=1, t=2, t=3}\right)-\left(\mathrm{CC}_{t}\right)}{(\mathrm{QHW})(1-\mathrm{TXRT})}$

$$
+\frac{\left(P E_{t}\right)(Q E)-\left(O M C_{t}\right)-(P T X)}{(Q H W)}
$$

The price of energy in year ( $t$ ) from (15) and the quantity of energy from

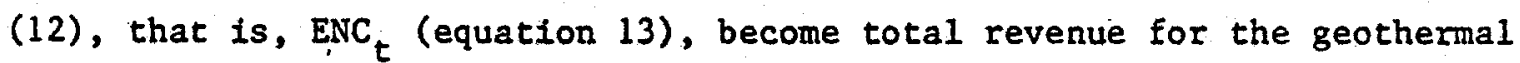
energy producer.

\section{Geothermal Energy Producer Sector}

We wIll recall equation (13) ENC $_{t}$ for the producer, REV $f$, or total revenues. Or,

(16) $\operatorname{REV}_{j}=\operatorname{ENC}_{t}$

First, a discussion of the time period involved is necessary. The producer's time horizon is different from that of the electric utility. The years $t$ are elements of $T$, while the years $j$ are elements of $J . J-T=P P Y$, the 
"pre-productionn years". PPY is composed of two periods. The exploration period (EXP) and the development period (DVP), and thus EXP+DVP=PPY.

Thus the determinative direction is EXP+DVP+T=J. EXP is the period during which only exploratory wells are drilled. The development period begins with the drilling of the first production well.

The producer's activity is modeled somewhat differently from the utilities because the output of the simulation is a rate of return on the producer's equity. Thus, the first order of business is to determine what the level of the investment is in each year of the project. The producer's investment $\left(\mathrm{PNV}_{j}\right)$ is a share of the total investment in year $j\left(\mathrm{PPK}_{j}\right)$.

$$
\begin{aligned}
& \text { (17) } \mathrm{PNV}_{j}=(\mathrm{EPK})\left(\mathrm{PKK}_{j}\right) \\
& (18) \mathrm{PKK}_{j}=\left(\mathrm{LNV}_{j}\right)+\left(\mathrm{DNV}_{j}\right)+\left(\mathrm{IDC}_{j}\right)+\left(\mathrm{OPNV}_{j}\right)
\end{aligned}
$$

EPK : Equity portion of capital; an input variable, LNV $_{j}$ : Leasing investment in year $j$, in $\$$, DNV $_{j}:$ Drilling lnvestment in year $j$, in $\$$, IDC $_{j}$ Interest cost during construction in year $f$, in $\$$, OPNV $_{j}$ : Other producer Investments in year $j$, in $\$$.

Total investment by the producer, cumulative to year $j$ is (19) $\mathrm{PK}_{j}=\sum_{i=0}^{j} \mathrm{PKK}_{1}$

We will first describe the calculation of each element of PKK $_{j}$, beginning with $\mathrm{DNV}_{j}$. 
(20) $\mathrm{DNV}_{j}=\left[\left(\frac{\mathrm{NPW}_{j}}{\mathrm{PSS}}\right)(\mathrm{ADDP})(\mathrm{CPFP})\right]+\left[\left(\frac{\mathrm{NIW}_{j}}{\mathrm{ISS}}\right)(\mathrm{ADDI})(\mathrm{CPFI})\right]$

$\mathrm{NPW}_{j}: \quad$ New producing wells in year $j$,

PSS: Production Well Success ratio,

CPFP: Cost per foot, producing wells,

$\mathrm{NIW}_{j}$ : New injection wells in year $j$,

ISS: Injection well success ratio ( 1 usually),

ADDI: Average depth of injection wells,

CPFI: Cost per foot of injection wells..

The calculation of the elements of $\mathrm{DNV}_{j}$ is shown below.

(21) $\mathrm{NPW}_{j}=R P W_{j}-\mathrm{RPW}_{j}-1$

$R P W_{j}$ : required producing. wells, $R P W_{j}=0$ when $j<E X P+1$.

(22) $\mathrm{RPW}_{j}=\frac{{ }^{R F R} \mathrm{CAP}}{\mathrm{FR}}$,

FR: Elowrate in $1 \mathrm{~b} / \mathrm{hr}$ per producing well.

$\mathrm{RFR}_{\mathrm{CAP}}$ : required flowrate for rated capacity in $\mathrm{Ib} / \mathrm{hr}$.

(CAP is stated here in $\mathrm{MW}_{\mathrm{W}}$, not $\mathrm{kw}$, and is net of UF.)

(23a) $R F R_{50}=1374.912 \mathrm{e}^{-0.01379 \text { (TEMP) }}$

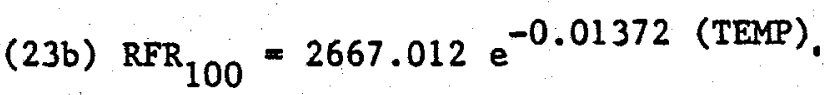

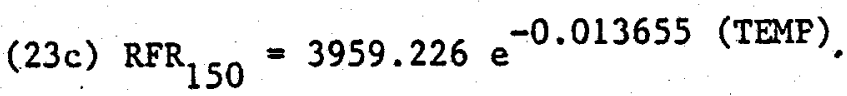

(23d) $\operatorname{RFR}_{200}=5251.44 \mathrm{e}^{-0.01359 \text { (TEMP) }}$ 
Temperature decline is estimated, and resulting need for increased flow. rate, thus producing wells, is modeled in the following way:

(24a) Temp $=\frac{T_{0}}{360}\left[358.344 e^{-0.00144(\text { Time) }}\right]$, for $\mathrm{CAP}=50 \mathrm{Mw}$.

(24b) Temp $=\frac{T_{0}}{360}\left[357.474 e^{-0.00233(T \text { Ime) }}\right]$, for CAP $=100 \mathrm{Mw}$.

(24c) Temp $=\frac{T_{0}}{360}\left[357.12 e^{-0.00322(\text { Time) }}\right]$, for CAP $=150 \mathrm{Mw}$.

(24d) Temp $=\frac{T_{0}}{360}\left[357.769 \mathrm{e}^{-0.00411(\mathrm{Time})}\right]$, for CAP $=200 \mathrm{Mw}$.

$\mathrm{T}_{0}$ : Initial temperature of brine in ${ }^{\circ} \mathrm{F}$, an input variable.

(25) $\mathrm{NIW}_{j}=R I W_{j}-\mathrm{RIW}_{j-1}$

$R I W_{j}$ : required injection wells in year $j$.

(26) $R I W_{j}=R P W_{j}(P I R)^{-1}$,

PIR: required ratio of producting wells to injection wells, in year $j$, an input variable.

After Initiation of power generation, $\mathrm{NPW}_{j}$ and $\mathrm{NIW}_{j}$ will generally take on a value of 0 or 1 , but are arbitrarliy allocated during DVP.

The remaining elements of $\mathrm{PKK}_{\mathbf{j}}$ are discussed below:

(27) $\mathrm{LNV}_{j}=\left[(\mathrm{DPAC})(\mathrm{ACPW})\left(\mathrm{NPW}_{j}\right)\right]+\left[(\mathrm{DPAC})(\mathrm{ACIW})\left(\mathrm{NIW}_{j}\right)\right]$

DPAC: dollars per acre leasing cost; input variable, ACPW: acres per producing well; input variable, ACIW: acres per injection well; input variable. 
(28) $\mathrm{OPNV}_{j}=\mathrm{EXPN}_{j}+\mathrm{PIPN}_{j}+\mathrm{ONV}_{j}{ }^{\prime}$

$\operatorname{EXPN}_{j}:$ exploration investments, year $j$,

PIPN $_{-j}$ : piping investments, year $j$,

$\mathrm{ONV}_{j}:$ other investments, year $j$.

(29) $\operatorname{EXPN}_{j}=f(\operatorname{EXPN})$

(30) $\operatorname{EXPN}=(\mathrm{EXD})(\mathrm{CAP})$

EXD: dollars per unit of capacity (electric) needed for exploration, on average; input variable,

$j>\operatorname{EXP}_{;} \operatorname{EXPN}_{j}=0$,

EXPN: total exploration investment in $\$$.

(Note: $\operatorname{EXPN}=\sum_{j=0}^{\operatorname{EXP}} \operatorname{EXPN}_{j}$, where the distribution function is chosen arbitrarily.)

(31) $\operatorname{EIPN}_{j}=(\operatorname{PIP})\left(\mathrm{DNV}_{j}\right)$

PIP: average percentage of drilling investment required for piping and similar field developments.

$$
j<\operatorname{EXP}+1, \operatorname{PIPN}_{j}=0: j>\operatorname{EXP}_{,} \operatorname{PIPN}_{j} \geq 0 .
$$

(32) $O N V_{j}=\left(O P E_{j}\right)\left(D N V_{j}\right)$.

(33) $O P E_{j}=(O P E B)(1+O P)^{j}$.

Equations (32) and (33) calculate estimate additional investments in field development which are related to drilling expenses. 


$$
\begin{aligned}
& \text { (34) } I D C_{j}=[B R][D P K]\left[\sum_{i=0}^{j} L_{i}+\sum_{i=0}^{j} D_{i}+\sum_{i=0}^{j} O P N V_{i}\right], \\
& I D C_{j}=0 \text { for } j>P P Y, \\
& \text { DPK: debt portion of capital; DPK }=1-E P K .
\end{aligned}
$$

Thus, total revenues and all elements of Investment have been calculated. What remain are uncapitalized elements of cost. OMCP $j$ are operating and other current outlays.

(35) $\mathrm{OMCP}_{j}=\left[\left(\mathrm{OCP}_{j}\right)\left(\mathrm{PK}_{j}\right)\right]+\left[(B R)\left(\mathrm{PK}_{j}\right)(D P K)\right]+\left[\operatorname{PTXP}_{j}\right]$.

(3.6) $O C P_{j}=(O C P B)(1+O C P)^{j}$

$\mathrm{OCP}_{j}$ : operating percentage of investment outlay,

OCPB: base percentage; Input variable,

óP: escalation factor,

$\operatorname{PTXP}_{j}$ : property taxes.

(37) $\operatorname{PTXP}_{j}=(P T P P)\left(P_{j}\right)$

PTPP: property tax rate; input variable.

Income taxes are as follows:

(38) $\operatorname{ITXP}_{j}=\{\operatorname{TXRT}\}\left\{\left[\left(\operatorname{REV}_{j}\right)(1-\lambda)(1-2)\right]-\left[\left(\mathrm{OMCP}_{j}\right)-(\mathrm{BR})\left(\mathrm{PK}_{j}\right)(\mathrm{DPK})\right]\right.$ $\left.-\left[(Y)\left(D N_{j}\right)\right]\right\}-\left\{[\operatorname{CRRT}]\left[(1-Y)\left(\sum_{i=j-2}^{j} D_{i}\right]\right\}\right.$.

(39) DNVD $=\sum_{i=1}^{j} \operatorname{DNV}_{i}\left(\operatorname{DEPRP}_{j-1+1}\right)$. 
(40) $\operatorname{DEPRP}_{j}=(D+1-j) / \sum_{j=1}^{D} j$,

D: period chosen for depreciation; input variable,

$\lambda$ : royalty rate, input variable,

Y: percentage tangible investment, input variable,

Z: depletion allowance, input variable,

$\mathrm{DNVD}_{j}$ : depreciation allowance in year $j, \$$,

DEPRP: depreciation rate in year $j$. Program contains fast write-off option.

Finally, the model solves for $R$, the rate of return to equity, for the geothermal energy producer from the Jth degree polynomial given by

(42) $\sum_{j=0}^{J}\left[\left[\left(\operatorname{REV}_{j}\right)(1-\lambda)-\left(\operatorname{OMCP}_{j}\right)-\left(\operatorname{IXPP}_{j}\right)\right]\right\} e^{-R j}=0$

The equation is solved for all real roots using the Newton-Raphson technique of numerical approximations. Of course this is simplified through the use of a computer. So long as the polynomial is monotomic, there will be only one non-imaginary root, which is the value of $R$. Thus far, the model has generated no non-monotonic equations.

The $R$ thus solved is one criterion for ranking geothermal resource sites and for comparing the outcomes of policy variable changes. 
APPENDIX C

THIRD QUARTERLY REGIONAL ADVISORY GROUP MEETING

RENO, NEVADA

March 8, 1978

\section{ATTENDEES}

Jim Kingsolver

Bob Forest

Ronald G. Hansen

Robert S. Sanchez

George Vranesh

Richard T. Meyer

Robert Oliver

Burt Barnes

John Leigh

Norman W. Melvin

T. W. Holland

David Wolf

Frank P. Mancin 1

Dick Hahman

Claudia Stone

RIchard H. Pearl

Barbara A. Coe

Martin Booth

Barbara Helseth

Dorls Weber

Ke1ly Jackson
Smith Tool Company

Phillips Petroleum Co.

Eyring Rsch. Inst.

Dept. of Interior

Vranesh \& Musick

Western Energy Planners

D.O.E. - D.G.E.

D.O.E. - D.G.E.

Mitre Corporation

Bureau of Land Management

Bureau of Land Management

Arizona Team

Arizona Solar Energy

Res. Commission

Arizona State Team

Arizona State Team

Colorado Geol. Survey

Colorado Geol, Survey

Nevada State Team

Nevada State Team

Nevada State Team

Nevada D.O.E.
Irvine, California

Reno, Nevada

Provo, Utah

Denver, Colorado

Boulder, Colorado

Denver, Colorado

Washington, D.C.

Washington, D.C.

Mclean, Va.

Reno, Nevada

Denver, Colorado

Tucson, Arizona

Phoenix, Arlzona

Tucson, Ar1zona

Tucson, Arizona

Denver, Colorado

Denver, Colorado

Reno, Nevada

Reno, Nevada

Reno, Nevada

Carson City, Nv. 
Page 2 - Attendees

Thomas A. Ortiz

D. G. Fedor

Wes Horner

Stanley Green

L. Ward Wagstaff

R. L. San Martin

Joe M. Marlin

C. R. Rao

R. E. Christ

P. L. O'Der
N.M. Energy Res. Board

N.M. Energy Res. Board

N.M. Energy Res. Board

Utah Div. of Water Rights

Utah Div. of Water Rights

New Mexico Energy Institute

New Mexico State UnIv.

New Mexico State UnIv.

New Mexico State Univ.

New Mexico State Univ.
Santa Fe, NM

Santa Fe, NM

Santa Fe, NM

Salt Lake City, UT

Salt Lake C1ty, UT

Las Cruces, NM

Las Cruces, $\mathrm{NM}$

Las Cruces, NM

Las Cruces, NM

Las Cruces, NM 